\author{
UNIVERSIDADE DE SÃO PAULO \\ ESCOLA DE ENGENHARIA DE SÃO CARLOS \\ DEPARTAMENTO DE HIDRÁULICA E SANEAMENTO
}

Raphaella de Abreu Magalhães Rodrigues

\title{
ESTUDO DO FITOPLÂNCTON E BACTERIOPLÂNCTON NO METABOLISMO DO NITROGÊNIO EM RESERVATÓRIOS SUBTROPICAIS
}

SÃO CARLOS 

Raphaella de Abreu Magalhães Rodrigues

\title{
ESTUDO DO FITOPLÂNCTON E BACTERIOPLÂNCTON NO METABOLISMO DO NITROGÊNIO EM RESERVATÓRIOS SUBTROPICAIS
}

\author{
Tese apresentada à Escola de \\ Engenharia de São Carlos, da \\ Universidade de São Paulo, como \\ parte dos requisitos para obtenção do \\ Título de Doutora em Ciências: \\ Hidráulica e Saneamento.
}

Orientadora: Prof. Titular Maria do Carmo Calijuri

VERSÃO CORRIGIDA

São Carlos

2020 


\begin{abstract}
AUTORIZO A REPRODUÇÃO TOTAL OU PARCIAL DESTE TRABALHO, POR QUALQUER MEIO CONVENCIONAL OU ELETRÔNICO, PARA FINS DE ESTUDO E PESQUISA, DESDE QUE CITADA A FONTE.
\end{abstract}

Ficha catalográfica elaborada pela Biblioteca Prof. Dr. Sérgio Rodrigues Fontes da EESC/USP com os dados inseridos pelo(a) autor(a).

\begin{tabular}{|c|c|}
\hline \multirow[t]{3}{*}{ R696e } & $\begin{array}{l}\text { Rodrigues, Raphaella de Abreu Magalhães } \\
\text { Estudo do fitoplancton e bacterioplăncton no } \\
\text { metabolismo do nitrogênio em reservatórios subtropicais } \\
\text { / Raphaella de Abreu Magalhães Rodrigues; orientador } \\
\text { Maria do Carmo Calijuri. São Carlos, 2020. }\end{array}$ \\
\hline & $\begin{array}{l}\text { Tese (Doutorado) - Programa de Pós-Graduação em } \\
\text { Engenharia Hidráulica e Saneamento e Area de } \\
\text { Concentração em Hidráulica e Saneamento -- Escola de } \\
\text { Engenharia de São Carlos da Universidade de São Paulo, } \\
2020 \text {. }\end{array}$ \\
\hline & $\begin{array}{l}\text { 1. Cianobactéria. 2. Bactérias heterotróficas. } \\
\text { 3. Citometria de fluxo. } 4 \text {. Análise metagenômica. I. } \\
\text { Titulo. }\end{array}$ \\
\hline
\end{tabular}

Eduardo Graziosi Silva - CRB - 8/8907 


\section{FOLHA DE JULGAMENTO}

Candidata: Licenciada RAPHAELLA DE ABREU MAGALHĀES RODRIGUES.

Título da tese: "Estudo do fitoplâncton e bacterioplâncton no metabolismo do nitrogênio em reservatórios subtropicais ".

Data da defesa: 04/08/2020.

\section{Comissāo Julgadora:}

\section{Resultado:}

Profa. Titular Maria do Carmo Callijuri

(Orientadora)

Dpnovidis

(Escola de Engenharia de São Carlos/EESC-USP)

Profa. Dra. Viviane Moshini Carlos

Apnoveds

(Universidade Estadual Paulista "Júlio de Mesquita Filho"/UNESP-Sdrocaba)

Prof. Dr. André Cordeiro Alves dos Sanilos

(Universidade Federal de São Carlos/UFSCar - Sorocaba)

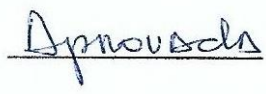

Profa. Dra. llolanda Cristina Silveira Duarte

(Universidade Federal de São Carlos/UFSCar)

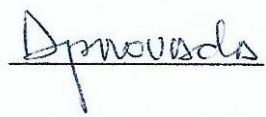

Profa. Associada Marli de Fórima Fiore

(Centro de Energia Nuclear na Agricultura/CENA-USP)

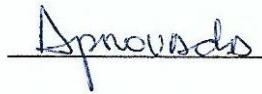

Coordenador do Programa de Pós-Graduação em Engenharia Hidráulica e Saneamento:

Prof. Dr. Eduardo Mario Mendiondo

Presidente da Comissão de Pós-Graduação:

Prof. Titular Murilo Araujo Romero 

Dedico esse trabalho ao meu amado marido que esteve comigo nos momentos mais alegres e desafiadores durante o desenvolvimento dessa tese; aos meus queridos pais por sempre me apoiarem e incentivarem a crescer. 



\section{AGRADECIMENTOS}

- A minha querida orientadora professora Titular Maria do Carmo Calijuri, que sempre me apoiou, incentivou e corroborou ativamente para realização desse grande sonho. Agradeço também pela confiança e paciência ao longo desses anos.

- Ao Programa de Pós-Graduação em Engenharia Hidráulica e Saneamento (PPGSHS) pela oportunidade de cursar Doutorado.

- O presente trabalho foi realizado com apoio da Coordenação de Aperfeiçoamento de Pessoal de Nível Superior - Brasil (CAPES) - Código de Financiamento 001 e do Conselho Nacional de Desenvolvimento e Pesquisa Tecnológica $(\mathrm{CNPq}$ - número do processo 142176/2016-8), por isso agradeço a CAPES e CNPq pelas bolsas de doutorado concedidas.

- À Fundação de Amparo à Pesquisa do Estado de São Paulo (FAPESP) pelo financiamento do projeto Auxílio à Pesquisa Regular (número do processo 2016/09405$1)$.

- Aos professores Dr. Hugo Sarmento e Dra. Marli Fiore por gentilmente fornecerem estrutura física e intelectual para o desenvolvimento de importantes etapas desse trabalho.

- Ao professor Dr. André Cordeiro Alves dos Santos, pela amizade e apoio ao longo do meu processo de formação acadêmica.

- À Dra. Adriana Cristina Poli Miwa Especialista do Laboratório de Biotoxicologia em Águas Continentais e Efluentes (BIOTACE), pela participação crucial neste trabalho, pelos ensinos, disponibilidade e muito mais do que tudo isso, pela sua amizade e por me ouvir e aconselhar nos momentos de desespero.

- Ao técnico de campo Miro e motorista Benê pelo auxílio nas coletas de campo. Obrigada pelos momentos de diversão, descontração, conselhos culinários e pelas comidinhas maravilhosas e inesquecíveis durante as viagens. Nunca vou me esquecer do bolo de milho, da parmegiana (sem ervilha), e da abóbora cabotiá refogada.

- Às funcionárias do Departamento de Hidráulica Sá e Priscila, pela paciência em tirar minhas dúvidas e por todo auxílio burocrático e acadêmico.

- Aos meus amados amigos do BIOTACE, Aline, Carol F., Carol B., Lucas, Fellipe, Flávia, Munique e Wesley pelos infinitos cafés, bolos, salgadinhos e cookies!

- A minha querida amiga Munique, especialmente, pela parceria incondicional durante todas as etapas desse trabalho. Tenho certeza de que essa jornada teria sido muito mais complicada se não tivéssemos trabalhado juntas. Obrigada pelo apoio pessoal e profissional.

- À Dra. Michaela Melo pelas valiosas contribuições em estatística e contribuições para o primeiro capítulo dessa tese. 
-Ao colega Gabriel Alcântara por gentilmente ter elaborado o gráfico dos mapas dos reservatórios. Obrigada pelo seu tempo e dedicação.

- Aos amigos de Piracicaba, Bruno e Juliana que me acolheram no laboratório durante as análises moleculares e que me deram apoio nos momentos difíceis.

- A minha família, por sempre me amar e apoiar, sem vocês essa jornada teria sido impossível. Obrigada mãezinha, paizinho de coração, maninha, cunhadinho querido, sobrinhas queridas e avós por ter me ajudado a chegar até aqui.

- Ao meu parceiro de vida, meu marido espetacular, por seu apoio e amor durante todo o desenvolvimento dessa tese, e até mesmo abdicou de seus próprios projetos para estar ao meu lado em São Carlos.

- A Deus por todas as oportunidades que tive na vida. 


\section{RESUMO}

RODRIGUES, Raphaella de Abreu Magalhães. Estudo do fitoplâncton e bacterioplâncton no metabolismo do nitrogênio em reservatórios subtropicais. 2020. 104 f. Tese (Doutorado em Ciências: Hidráulica e Saneamento). Escola de Engenharia de São Carlos, Universidade de São Paulo, São Carlos, 2020.

O fitoplâncton e bacterioplâncton são amplamente distribuídos em ecossistemas aquáticos, além disso são componentes fundamentais para a estrutura das teias alimentares e manutenção de ciclos biogeoquímicos. $O$ nitrogênio é um elemento essencial para o crescimento desses microrganismos, por isso a crescente e excessiva entrada de nutrientes nitrogenados na água em reservatórios é capaz de alterar a dinâmica dessas comunidades. Geralmente o fitoplâncton e o bacterioplâncton não são estudados simultaneamente, e pouco se conhece sobre os seus papéis no metabolismo do nitrogênio em reservatórios subtropicais. Diante do exposto, o objetivo geral dessa pesquisa foi caracterizar as comunidades fitoplanctônicas e bacterianas, além de avaliar a influência delas sobre rotas metabólicas do nitrogênio, em dois reservatórios subtropicais, Itupararanga e Lobo localizados no estado de São Paulo (Brasil). No capítulo 1 é apresentada uma visão geral sobre a estrutura das comunidades bacterianas e fitoplanctônicas, incluindo o picofitoplâncton que é frequentemente não avaliado em muitos estudos realizados em reservatórios. As comunidades microbianas apresentaram variação espaço-temporal e bactérias heterotróficas foram correlacionadas com $\mathrm{o}$ fitoplâncton. As picocianobactérias ricas em ficocianinas co-dominaram com $\mathrm{o}$ picofitoplâncton eucarionte na maioria das amostras. As variáveis ambientais que influenciaram as três comunidades foram $\mathrm{pH}$, condutividade elétrica e transparência da água, entretanto o nitrogênio inorgânico dissolvido (DIN) e carbono orgânico dissolvido (DOC) foram importantes estruturadores do fitoplâncton e de bactérias heterotróficas. No capítulo 2 são abordadas as relações entre a composição microbiana com o metabolismo do nitrogênio. As análises metagenômicas e experimentos com traçadores isotópicos $\left({ }^{15} \mathrm{~N}_{-} \mathrm{NO}_{3}{ }^{-} \mathrm{e}^{15} \mathrm{~N}^{-\mathrm{NH}_{4}}{ }^{+}\right)$mostraram que cianobactérias desempenham um papel chave nas rotas metabólicas do nitrogênio, uma vez que esses microrganismos apresentaram alto potencial genético para fixação de nitrogênio atmosférico e alto potencial para assimilação de nitrato. Entre as cianobactérias, Nostocaceae foi a família mais abundante e foi representada principalmente por Raphidiopsis raciborskii na barragem de Itupararanga. Entre bactérias heterotróficas, foram observadas altas abundancias relativas de Burkholderiaceae e Comamonadaceae. Genes associados aos processos de assimilação de amônio, amonificação e desnitrificação foram taxonomicamente filiados a diferentes famílias de bactérias heterotróficas. Entretanto, em ambos os reservatórios a comunidade microbiana apresentou baixo potencial genético para desnitrificação e genes associados a processos de nitrificação não foram detectados. Por fim, essa pesquisa mostrou que o uso de diversas ferramentas para estudo do fitoplâncton e bacterioplâncton, simultaneamente, é muito importante para ampliar os conhecimentos sobre estrutura e metabolismo desses microrganismos em ambientes aquáticos.

Palavras-chave: Análise metagenômica. Citometria de fluxo. Cianobactéria. Bactérias heterotróficas. 



\begin{abstract}
RODRIGUES, Raphaella de Abreu Magalhães. Study of phytoplankton and bacterioplankton on nitrogen metabolism in subtropical reservoirs. 2020. $104 \mathrm{f}$. Tese (Doutorado em Ciências: Hidráulica e Saneamento). Escola de Engenharia de São Carlos, Universidade de São Paulo, São Carlos, 2020.

The phytoplankton and bacterioplankton are widely distributed in aquatic ecosystems. They are key components for the structure of the food webs and maintenance of biogeochemical cycles. Nitrogen is an essential element for the growth of these microorganisms, so the increasing and excessive inputs of nitrogenous nutrients in the water can change the dynamics of these communities. Phytoplankton and bacterioplankton are usually not studied simultaneously, and little information are fund about their role in nitrogen metabolism in subtropical reservoirs. Given the above, the general aim of this research was to characterize the phytoplanktonic and bacterial communities and assess their influence on nitrogen metabolic paths in two subtropical reservoirs, Itupararanga and Lobo located in São Paulo (Brazil). Chapter 1 provides an overview of the structure of bacterial and phytoplankton communities, including picophytoplankton, which is often not evaluated in many studies. Microbial communities showed spatiotemporal variation and heterotrophic bacteria were correlated with phytoplankton. Phycocyanin-rich picocyanobacterial co-dominated with eukaryotic picophytoplankton in many samples. The environmental variables that have influenced the three communities were $\mathrm{pH}$, electrical conductivity and water transparency, however, dissolved inorganic nitrogen (DIN) and dissolved organic carbon (DOC) were important structuralists of phytoplankton and heterotrophic bacteria. In chapter 2, the relationship between microbial composition and nitrogen metabolism is presented. Metagenomic analyzes and experiments with isotopic tracers $\left({ }^{15} \mathrm{~N}_{-} \mathrm{NO}_{3}{ }^{-}\right.$and $\left.{ }^{15} \mathrm{~N}-\mathrm{NH}_{4}{ }^{+}\right)$showed that cyanobacteria play a key role in the metabolic pathways of nitrogen. These microorganisms had high genetic potential for fixing atmospheric nitrogen and high potential for nitrate assimilation. Among cyanobacteria, Nostocaceae was the most abundant family and was represented mainly by Raphidiopsis raciborskii in the Itupararanga dam zone. Within heterotrophic bacteria, high relative abundances of Burkholderiaceae e Comamonadaceae were observed. Genes associated with ammonium assimilation, ammonification and denitrification process were taxonomically linked to different families of heterotrophic bacteria. However, in both reservoirs the microbial community showed low genetic potential for denitrification and genes related to nitrification processes were not detected. Finally, this research showed that the use of several tools to study phytoplankton and bacterioplankton simultaneously is especially important to expand knowledge about the structure and metabolism of these microorganisms in aquatic environments.
\end{abstract}

Keywords: Metagenomic analysis. Flow cytometry. Cyanobacteria. Heterotrophic bacteria. 



\section{LISTA DE ILUSTRAÇÕES}

\section{INTRODUÇÃO GERAL}

Figura 2. Esquema representando as transformações de nitrogênio para o processo de assimilação de amônio, forma nitrogenada, assimilável pelos microrganismos. 25

Figura 3. Transformações metabólicas do nitrogênio e principais genes envolvidos nos processos biológicos

\section{CAPÍTULO 1 - Spatiotemporal structure of phytoplankton, picophytoplankton and heterotrophic bacteria in subtropical reservoirs}

Figure 1-1. Map of the studied reservoirs (Lobo and Itupararanga) with the locations of sampling sites, river zone and zone close to the dam.

Figure 1-2. Carbon biomass of phytoplankton, picophytoplankton and heterotrophic bacteria: (a) Itupararanga reservoir (b) Lobo reservoir. 48

Figure 1-3. Non-metric multidimensional scaling (NMDS) ordination based on Bray Curtis dissimilarity matrix of a) phytoplankton genera/species biomass; b) picophytoplankton cytometric fingerprint; c) heterotrophic bacteria cytometric fingerprint.

Figure 1-4. Distance-based redundancy analysis (dbRDA) a) phytoplankton biomass composition with environmental factors; b) coordinates of phytoplankton samples; c) picophytoplankton cytometric fingerprint with environmental factors; d) coordinates of picophytoplankton samples; e) heterotrophic bacteria cytometric fingerprint with environmental factors; f) coordinates of heterotrophic bacteria samples. Chl chlorophyll, Cond conductivity, DIN dissolved inorganic nitrogen, $D O$ dissolved oxygen, DOC dissolved organic carbon, $N P$ nitrogen and phosphorus ratio, Temp temperature, Transp transparency, TSS total suspended solids.

Figure S1-1. Vertical profile of temperature, $\mathrm{pH}$ and dissolved oxygen in Itupararanga reservoir: (a) river zone; (b) dam zone

Figure S1-2. Vertical profile of temperature, $\mathrm{pH}$ and dissolved oxygen in the Lobo reservoir: (a) river zone; (b) dam.

Figure S1-3. Contribution of eukaryotic picophytoplankton (Peuk) and picocyanobacteria rich in phycocyanin (PC-rich Pcy) and phycoerythrin (PE-rich Pcy) to the total biomass of picophytoplankton (PPP). a) Itupararanga river zone; b) Itupararanga dan; c) Lobo river zone; d) Lobo dam. 68 


\section{CAPÍTULO 2 - Linking aquatic microbial communities to nitrogen cycling in subtropical reservoirs}

Figure 2-1. Map showing the location of the Itupararanga and Lobo reservoirs with sampling sites (dam zone and river zone).

Figure 2-2. Biovolume contribution (\%) of phytoplankton classes in (A) the Itupararanga reservoir and in (B) the Lobo reservoir, in May/2017, August/2017, October/2017 and January/2018. Classes with biovolume below 5\% were presented in "Others".

Figure 2-3. Biovolume contribution (\%) of the phytoplankton genera/species of (A) the Itupararanga reservoir and (B) teh Lobo reservoir, in May/2017, August/2017, October/2017 and January/2018. Classes with biovolume below 5\% were presented in "Others". 80

Figure 2-4. Distance-based redundancy analysis (db-RDA) between phytoplankton community composition and environmental variables. Abbreviations - I: Itupararanga reservoir; L: Lobo reservoir; DZ: dam zone; RZ: river zone; M: May/2017, J: January/2018; Temp: temperature; Cond: conductivity; DOC: dissolved organic carbon; NP nitrogen and phosphorus ratio; Ank: Ankistrodesmus fusiformes; Apha: Aphanocapsa sp.; Aul1 Aulacoseira granulata; Aul2: Aulacoseira distans; Cer: Ceratium furcoides; Cry: Cryptomonas sp.; Cyc: Cyclotella meneghiniana; Dis: Discotella stelligera; Fra: Fragilaria grunowii; Mono: Monoraphidium contortum; Per: Peridinium; Rap: Raphidiopsis raciborskii; Rhi: Rhizosolenia sp. 81

Figure 2-5. Contribution (\%) of heterotrophic bacteria (HB) and phytoplankton (PHY) to the total $\mathrm{N}$ uptake $\left(\mathrm{NO}_{3}{ }^{-}\right.$uptake+ $\mathrm{NH}_{4}{ }^{+}$uptake). The figure displays a boxplot with the percentage calculated from all Itupararanga and Lobo experimental samples

Figure 2-6. Total Nitrogen uptake rates (sum of $\mathrm{NO}_{3}{ }^{-}$uptake and $\mathrm{NH}_{4}{ }^{+}$uptake) in river zone and dam zone samples from the (A) Itupararanga reservoir and the (B) Lobo reservoir. Samples were collected in May/2017, August/2017, October/2018, and January/2018. 83

Figure 2-7. Relative abundance (\%) of bacterial phyla in water samples collected in the river zone (RZ) and in the dam zone (DZ) from the Itupararanga (I) and Lobo (L) reservoirs, in May/2017 (M) and January/2018 (J). "Others" represent phyla with less than $1 \%$ of abundance 84

Figure 2-8. Relative abundance (above 1\%) of bacterial families in metagenomes from Itupararanga and Lobo reservoir. Abbreviations means I: Itupararanga reservoir; RZ: River zone; DZ: Dam zone; L: Lobo reservoir. 85 
Figure 2-9. Distance-based redundancy analysis (db-RDA) between bacterial community composition at family level (with relative abundance above 1\%) and environmental variables. Abbreviations: I: Itupararanga reservoir; L: Lobo reservoir; DZ: dam zone; RZ: river zone; M: May/2017, J: January/2018; Cond: electric conductivity, DOC: Dissolved organic carbon; NP nitrogen and phosphorus ratio; Com: Comamonadaceae; Burk: Burkholderiaceae; Chro: unclassified derived from Chroococcales; Myco: Mycobacteriaceae; Nost: Nostocaceae; Strep: Streptomycetaceae; Methy: Methylophilaceae; Ent: Enterobacteriaceae; Flav: Flavobacteriaceae; Rhod: Rhodocyclaceae; Baci: Bacillaceae. 86

Figure 2-10. SEED subsystems (at level 1) with significant differences in metagenomes from the Itupararanga reservoir. Positive differences between proportions denote gene overrepresentation in the dam zone (blue), whereas negative differences between proportion denote overrepresentation in the river zone (blue).

Figure 2-11. SEED subsystems (at level 1) with significant differences in metagenomes from the Lobo reservoir. Positive differences between proportions denote gene overrepresentation in January/2018 (black), whereas negative differences between proportion denote overrepresentation in May/2017 (gray)

Figure 2-12. Significant differences between functional genes classified according to SEED subsystems in metagenomes from the Itupararanga reservoir. (A) "Genes related to Nitrogen metabolism" category and (B) genes related to "Nitrate and nitrite ammonification" category. 88

Figure 2-13. Number of sequences of the bacterial families related to Nitrogen metabolism categories according to SEED subsystem and NCBI RefSeq data base. (A) Ammonium Assimilation, (B) Nitrogen fixation, (C) Nitrate and nitrite ammonification and (D) Denitrification.

Figure S2-1. Functional profile at level 1 based on SEED subsystems of metagenomes obtained from river zone and dam zone in May/2017 and January/2018 in (A) Itupararanga reservoir and (B) Lobo reservoir. I: Itupararanga; RZ: River zone; DZ: Dam zone; L: Lobo...... 105

Figure S2-2. Significant differences in genes within "Virulence, Disease and Defense category" classified according SEED subsystems in metagenomes from Itupararanga reservoir. 106 



\section{LISTA DE TABELAS}

CAPÍTULO 1 - Spatiotemporal structure of phytoplankton, picophytoplankton and heterotrophic bacteria in subtropical reservoirs

Table 1-1. Mean values and range of the environmental parameters measured in the Itupararanga and Lobo reservoirs

Table 1-2. Mean values and range of microbial communities biomass in the river zone and dam of Itupararanga and Lobo reservoirs.

Table 1-3. Permutational multivariate analysis of variance (PERMANOVA) results for the structure of phytoplankton(PHY) and heterotrophic bacteria (HB). 52

\section{CAPÍTULO 2 - Linking aquatic microbial communities to nitrogen cycling in} subtropical reservoirs

Table 2-1. Physical, chemical and biological variables of water in Itupararanga and Lobo reservoirs .77

Table S2-1. N uptake rates (nmol L- ${ }^{1} \mathrm{~h}^{-1}$ ) by phytoplankton measured in Itupararanga and Lobo reservoirs. The percent contribution of each substrate to total nitrogen uptake is indicated in parentheses...................................................... 104

Table S2-2 Number of metagenomic reads and Domain contribution in Itupararanga and Lobo reservoirs. 104 



\section{SUMÁRIO}

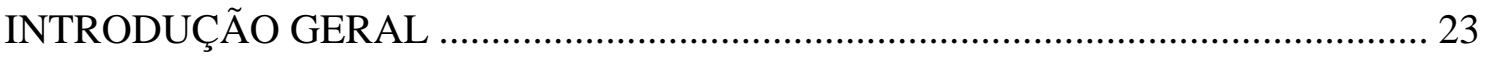

Ciclo do nitrogênio …………………………………………………………. 23

O fitoplâncton e bacterioplâncton no metabolismo do nitrogênio................................. 27

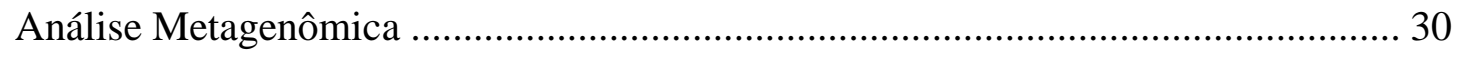

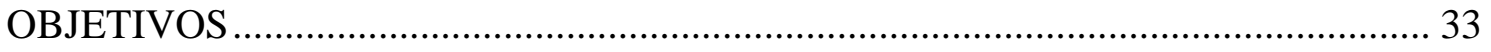

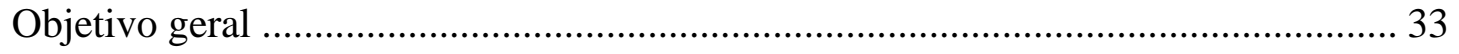

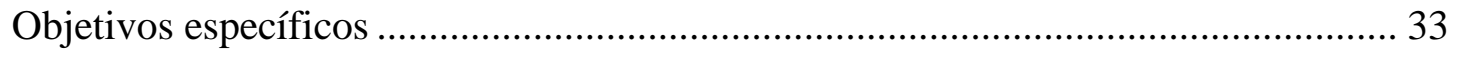

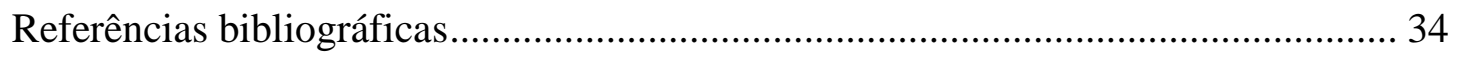

CAPÍTULO 1- Spatiotemporal structure of phytoplankton, picophytoplankton and

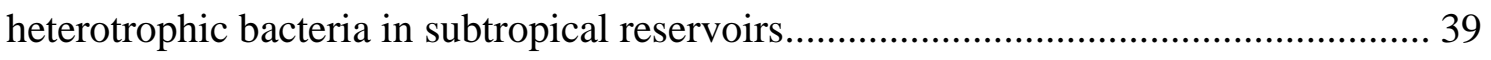

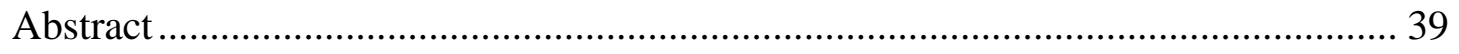

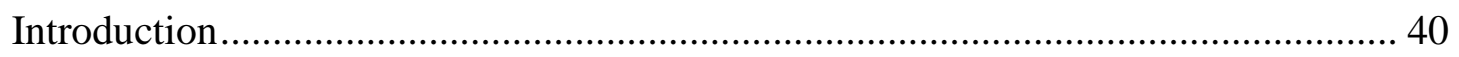

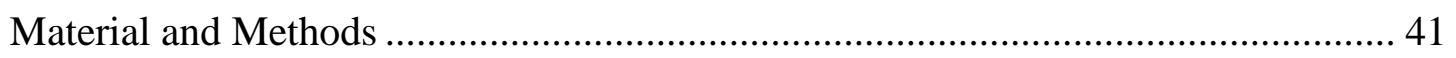

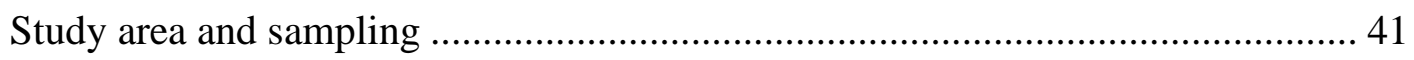

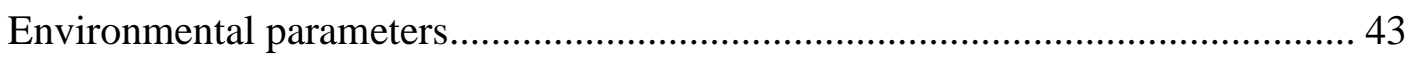

Community biomass analyses ........................................................................... 43

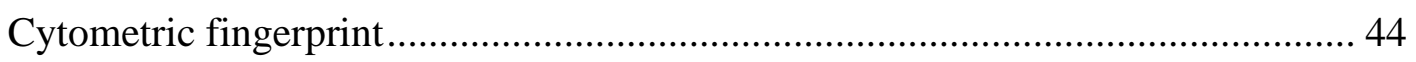

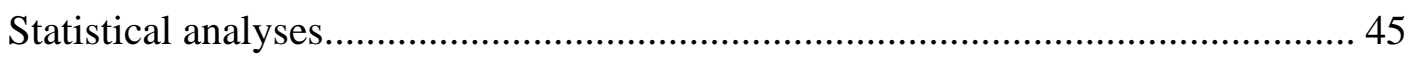

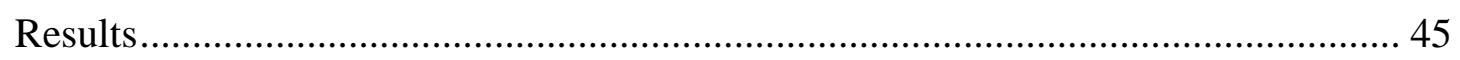

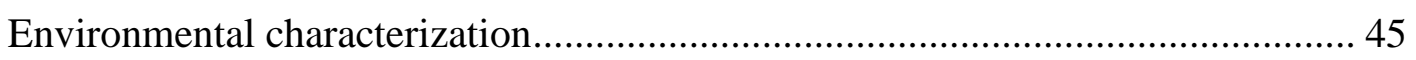

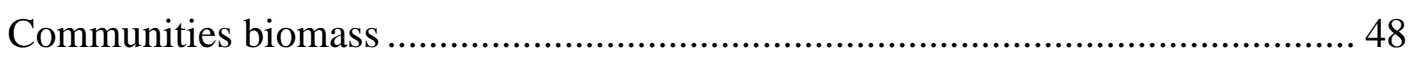

Spatiotemporal patterns on communities structure ……………………………...... 49

Influence of environmental factors on communities ............................................ 52

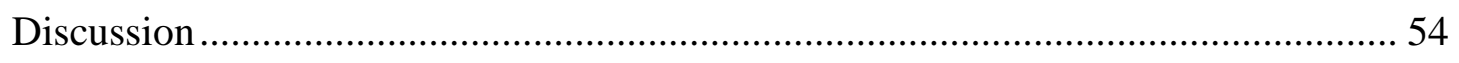

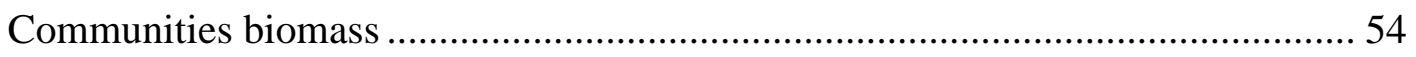

Spatiotemporal patterns in community structure ………………………………... 55

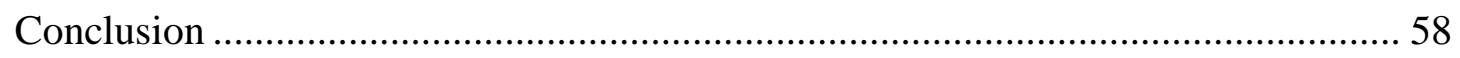

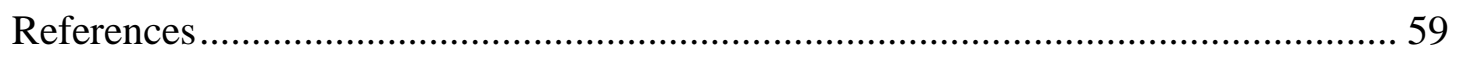

CAPÍTULO 2 - linking aquatic microbial communities to nitrogen cycling in subtropical

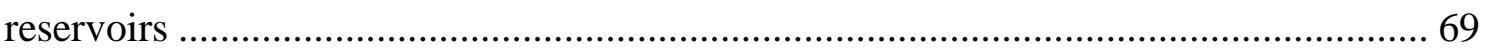

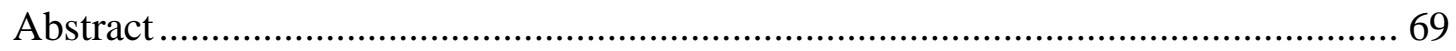

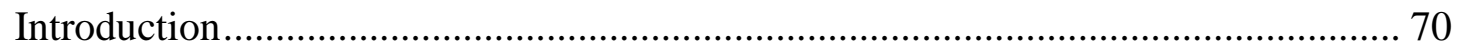




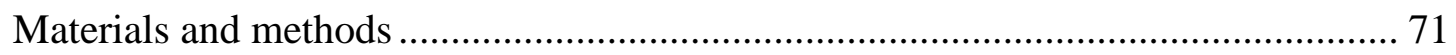

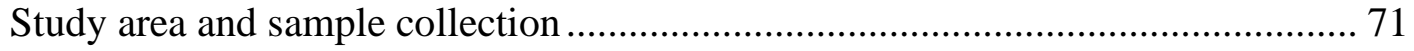

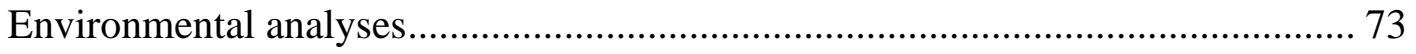

Nitrogen uptake experiments by total community ….......................................... 74

DNA extraction and Shotgun metagenomic sequencing.................................... 74

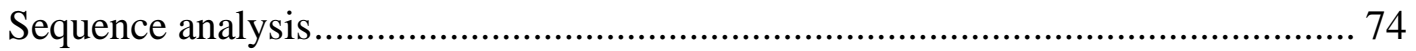

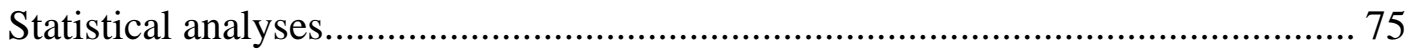

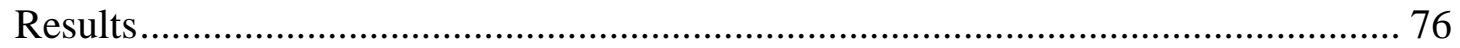

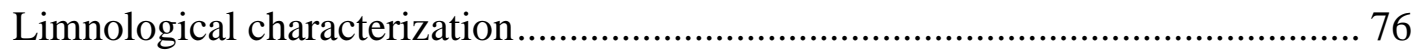

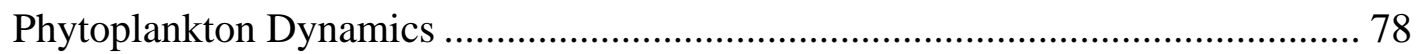

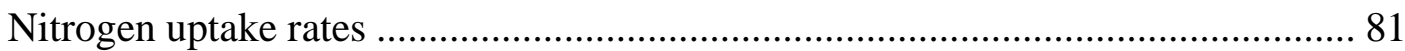

Taxonomic characterization of bacterial communities ........................................ 83

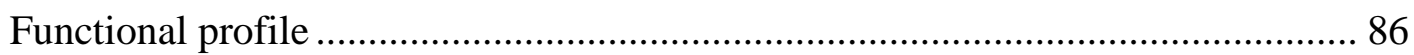

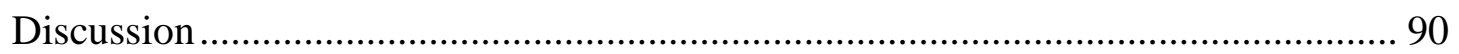

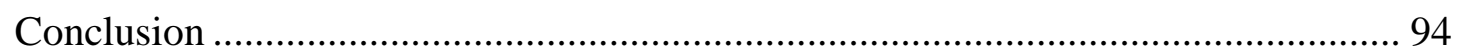

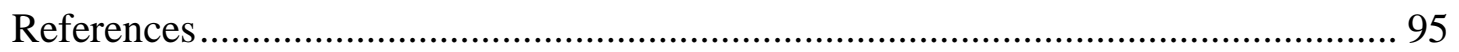

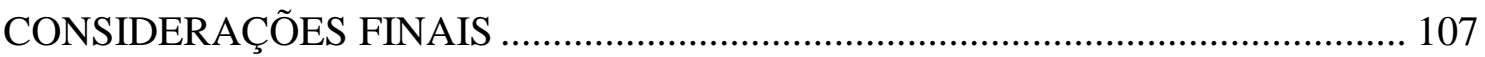




\section{INTRODUÇÃO GERAL}

\section{Ciclo do nitrogênio}

O nitrogênio $(\mathrm{N})$ é um dos elementos mais importantes na natureza, pois é constituinte fundamental de macromoléculas essenciais ao metabolismo celular (CAPONE, 2000). Em ecossistemas aquáticos esse elemento é encontrado na fração orgânica dissolvida (aminoácidos, proteínas, ácidos nucleicos e ureia) e particulada (organismos), ou na fração inorgânica dissolvida, com $\mathrm{N}$ sob diferentes estados de oxidação (DODDS; WHILES, 2010). Os principais compostos nitrogenados inorgânicos disponíveis na água, com seus respectivos estados de oxidação, são a amônia ( $\left.\mathrm{NH}_{3},-\mathrm{III}\right)$, o nitrogênio molecular $\left(\mathrm{N}_{2}, 0\right)$, o óxido nitroso $\left(\mathrm{N}_{2} \mathrm{O},+\mathrm{I}\right)$, o íon amônio $\left(\mathrm{NH}_{4}{ }^{+},+\mathrm{III}\right), \mathrm{o}$ nitrito $\left(\mathrm{NO}_{2}^{-},+\mathrm{IV}\right)$ e o nitrato $\left(\mathrm{NO}_{3}^{-},+\mathrm{V}\right)$ (WETZEL, 2001; STEIN; KLOTZ, 2016). A formação dessa diversidade de compostos é intermediada por uma complexidade de reações bioquímicas realizadas por microrganismos, constituindo o ciclo do nitrogênio (CANFIELD; GLAZER; FALKOWSKI, 2010).

Um dos processos importantes neste ciclo biogeoquímico é a fixação biológica de nitrogênio, que se consiste em reduzir o $\mathrm{N}_{2}$ a NH$_{4}{ }^{+}$(ZEHR, 2011). Para quebrar a tripla ligação presente no $\mathrm{N}_{2}$, o metabolismo celular demanda elevada quantidade de energia, por isso, somente os microrganismos que possuem o complexo enzimático nitrogenase são capazes de fixar $\mathrm{N}_{2}$ (DODDS; WHILES, 2010). O sistema nitrogenase é codificado pelos genes nifH, nifD, nifK (ZEHR et al., 2003). O nifH é encontrado em diversos grupos de microrganismos pertencentes ao domínio Bacteria (RIEMANN; FARNELID; STEWARD, 2010; ZEHR, 2011) e tem sido muito usado para identificar potenciais espécies fixadoras de nitrogênio presentes no ambiente (JENKINS; ZEHR, 2008).

No entanto, muitos microrganismos aquáticos não possuem os genes que codificam a nitrogenase, e, portanto, obtêm $\mathrm{N}$ através da assimilação de compostos nitrogenados disponíveis na água, tais como $\mathrm{NH}_{4}{ }^{+}, \mathrm{NO}_{3}{ }^{-}$, aminoácidos e ureia (MULHOLLAND; LOMAS, 2008).

As vias assimilatórias do nitrogênio no metabolismo celular requerem que o $\mathrm{N}$ esteja na forma de amônio, sendo assim, quando os microrganismos assimilam $\mathrm{NO}_{3}{ }^{-}$, este precisa ser reduzido a $\mathrm{NO}_{2}$ pela ação da nitrato redutase, para subsequente redução a $\mathrm{NH}_{4}{ }^{+}$, por intermédio de enzimas nitrito redutases (DODDS; WHILES, 2010). 
As enzimas nitrato redutases possuem as mesmas funções em microrganismos procariontes e eucariontes, no entanto os genes que as codificam diferem-se entre si. De maneira geral, em algas, a nitrato redutase é codificada por euk-nr, enquanto em procariontes são encontradas diferente tipos de nitrato redutases. As vias assimilatórias são controladas pelos genes nas e nar (ALLEN et al., 2001; ALLEN; WARD; SONG, 2005; ZEHR; KUDELA, 2011). Também existem diferentes tipos de nitrito redutases, codificadas principalmente pelos genes nir (CANFIELD; GLAZER; FALKOWSKI, 2010). Em uma via contrária a assimilatória do nitrato, em condições limitantes de oxigênio, pode ocorrer o processo de dissimilação do nitrato a amônio (DRNA). Nessa via metabólica, nitrito é reduzido a amônio por bactérias que contém nitrito redutases específicas, codificadas pelo gene $n r f$ (NIZZOLI et al., 2010; KRAFT; STROUS; TEGETMEYER, 2011).

A assimilação do amônio pelo fitoplâncton e pelas bactérias envolve reações bioquímicas catalisadas, principalmente, pelas enzimas glutamina sintetase (GS) e glutamato sintase (GOGAT, glutamina 2-oxoglutarato aminotransferase) (BERGES; MULHOLLAND, 2008; GLIBERT et al., 2016). Primeiro, a enzima GS participa do processo de incorporação do $\mathrm{NH}_{4}{ }^{+}$ao grupo amida da glutamina, e, posteriormente, a GOGAT catalisa a reação entre a glutamina e ácido alfa-cetoglutarato para a produção de duas moléculas de glutamato, sendo que, uma pode ser usada para a produção de uma nova molécula de glutamina, e a outra para a biossíntese de compostos orgânicos (Figura 1) (CAPONE, 2000; GLIBERT et al., 2016). 
Figura 1. Esquema representando as transformações de nitrogênio para o processo de assimilação de amônio, forma nitrogenada, assimilável pelos microrganismos.

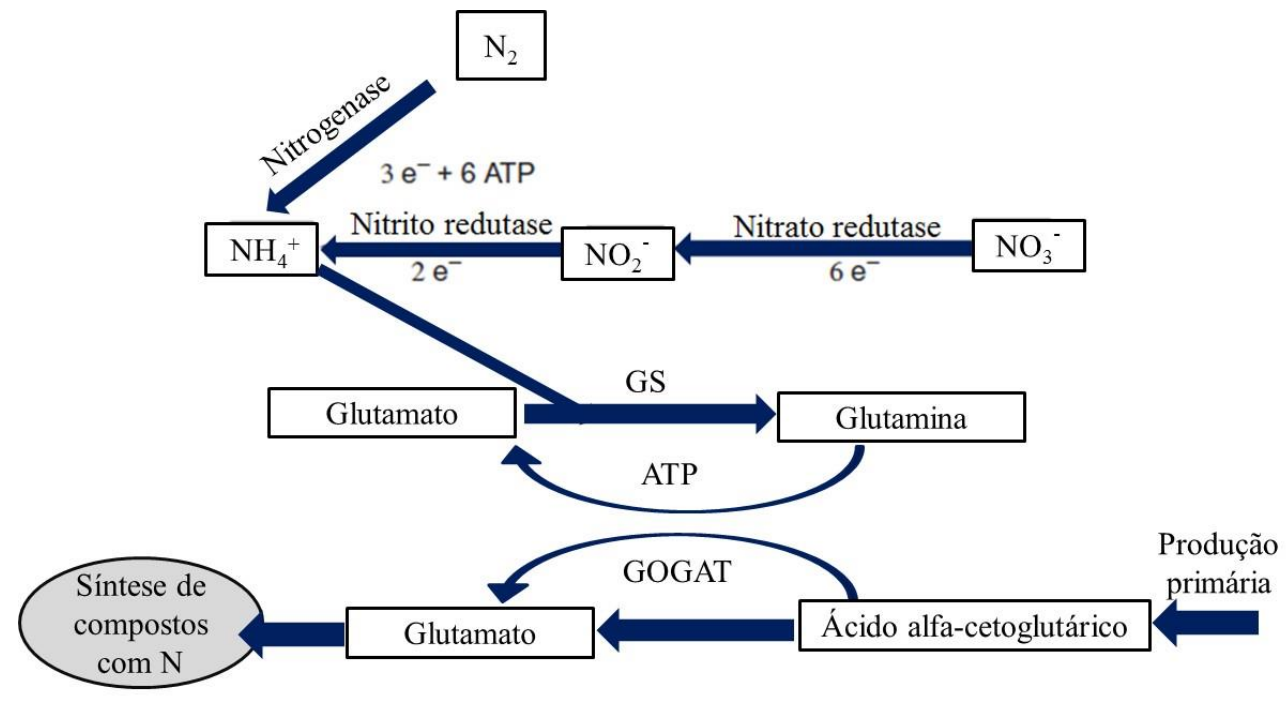

Fonte: Modificada de Dodds e Whiles (2010).

Existem três tipos de enzimas GS, codificadas por genes diferentes, de acordo com o grupo de microrganismos ao qual pertencem. A GSI é codificada pelo gene $g \ln A$, e está presente em microrganismos pertencente ao domínio Bacteria (CAPONE, 2000). A GSII, codificada pelo gene $g \ln I I$, é frequentemente encontrada em eucariontes e em algumas bactérias, e a GSIII, codificada pelos genes $g \ln T$ e $g \ln N$, está presente em algumas cianobactérias não diazotróficas, e em alguns grupos de algas, como por exemplo diatomáceas ((BERGES; MULHOLLAND, 2008). Também existem três classes de enzimas GOGAT, a GOGAT-ferrodoxina-dependente, que é codificada pelo gene $g l s F$, as enzimas GOGAT, NADH ou NADPH-dependentes que são codificadas pelos genes gltB e (BERGES; MULHOLLAND, 2008).

Estudos indicam que, tanto o fitoplâncton como as bactérias heterotróficas, são capazes de assimilar nitrogênio orgânico sob a forma de ureia. Uma vez dentro das células, a enzima urease catalisa a hidrólise de ureia, formando duas moléculas de $\mathrm{NH}_{4}{ }^{+}$, as quais podem ser transformadas em N orgânico (BERGES; MULHOLLAND, 2008). A urease é constituída por três subunidades estruturais, codificadas por genes considerados altamente conservativos (ureA, ureB e ureC), e por quatro proteínas acessórios (codificadas por ureD, ureE, ureF e ureG). Bradley et al., 2010 utilizou o gene ureC identificar microrganismos envolvidos no processo de assimilação de ureia em um ambiente marinho. 
Depois de assimilado pelas células, o nitrogênio orgânico pode voltar ao meio na forma de íon amônio, através do processo de mineralização, também conhecido por amonificação, ou pela excreta de animais.

O íon amônio disponível no meio poderá ser novamente assimilado pelos microrganismos, ou, na presença de oxigênio, ser oxidado a nitrato. Esse processo, chamado de nitrificação, ocorre em duas etapas pela ação de microrganismos de diferentes taxa. Na primeira, através da ação da enzima amônia mono-oxigenase (codificada por amo), o $\mathrm{NH}_{4}$ é oxidado a hidroxilamina $\left(\mathrm{NH}_{2} \mathrm{OH}\right)$, e esta por sua vez é oxidada a nitrito pela ação da enzima hidroxilamina oxiredutase. $\mathrm{Na}$ segunda etapa, o nitrito é oxidado a nitrato pela ação de bactérias que contém a enzima nitrito oxiredutase (GELDA et al., 2000; CANFIELD; GLAZER; FALKOWSKI, 2010).

$\mathrm{O} \mathrm{N}_{2}$ retorna para o meio aquático por meio dos processos anammox (anaerobic ammonium oxidation) e desnitrificação. Ambos, geralmente, ocorrem no sedimento, e são permeados por série de reações bioquímicas que ocorrem sob condições anaeróbias (LAVERMAN et al., 2007).

As reações de desnitrificação se consistem em reduzir o $\mathrm{NO}_{3}{ }^{-}$a $\mathrm{N}_{2}$ através do metabolismo de microrganismos desnitrificantes, que podem estar distribuídos em diferentes classes do filo bacteriano Proteobacteria (ZUMFT, 1997). O $\mathrm{NO}_{3}{ }^{-}$é transformado em $\mathrm{NO}_{2}{ }^{-}$por intermédio das nitrato redutases dissimilatórias (codificadas pelos genes nap ou por nar). $\mathrm{O} \mathrm{NO}_{2}{ }^{-}$é então reduzido a óxido nítrico (NO) por intermédio de enzimas nitrito redutases (codificadas principalmente por nir), e NO é transformado a óxido nitroso $\left(\mathrm{N}_{2} \mathrm{O}\right)$ pela óxido nítrico redutase (codificada por nor). Por último, a oxido nitroso redutase (codificada por noz) catalisa a reação de redução do $\mathrm{N}_{2} \mathrm{O}$ a $\mathrm{N}_{2}$ (ZUMFT, 1197; JENKINS; ZEHR, 2008).

No processo anammox o $\mathrm{N}_{2}$ retorna ao meio pela oxidação de amônio com nitrito em condições anaeróbicas. As principais enzimas envolvidas nos processos de anammox são a hidroxilamina oxidoreductase, hidrazina oxidante e hidrazina hidrolase (KRAFT; STROUS; TEGETMEYER, 2011). Essa via metabólica é muito pouco estudada em ecossistemas aquáticos continentais, principalmente em ambientes subtropicais.

A Figura 2 apresenta, de maneira simplificada, as vias metabólicas de transformação do nitrogênio e os principais genes que codificam as enzimas envolvidas nos processos biológicos. 
Figura 2. Transformações metabólicas do nitrogênio e principais genes envolvidos nos processos biológicos

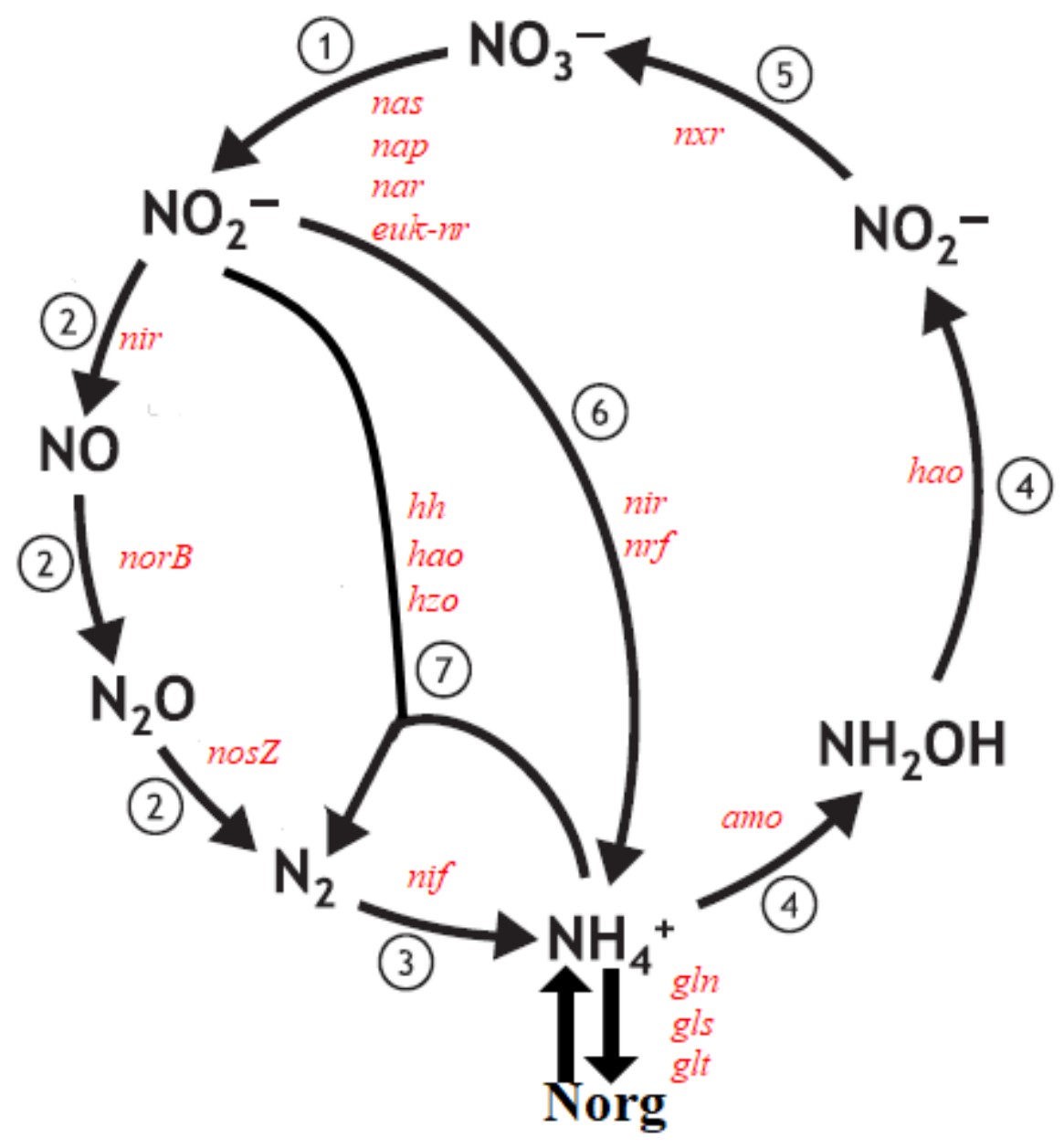

Os números indicam os processos: 1 - redução do nitrato; 2- desnitrificação; 3- fixação de nitrogênio; 4- oxidação aeróbica do amônio; 5- oxidação aeróbica do nitrito; 6- redução dissimilatória do nitrito a amônio ou redução do nitrito; 7- oxidação anaeróbica do amônio. Em vermelho constam os genes que codificam as enzimas que catalisam as reações. Nitrato redutases ( nas, nar, nap, euk-nr), nitrito redutases (nir, nrf), óxido nítrico redutase (norB), óxido nitroso redutase (nosZ). Nitrogenase (nif), nitrito oxiredutase ( $x x r)$, mono-oxigenase de amônio (amo), hidroxilamina oxidoredutase ( $h a o$ ), hidrazina oxidante $(h z o)$, hidrazina-hidrolase $(h h)$, glutamina sintetase $(g l n)$, glutamina 2-oxoglutarato aminotransferase $(g l s$ e $g l t)$. Fonte: Modificado de Rasigraf et al (2017).

\section{O fitoplâncton e bacterioplâncton no metabolismo do nitrogênio}

O fitoplâncton é um dos principais contribuintes para a produção primária microbiana em ambientes aquáticos (POMEROY, 1974), enquanto bactérias são fundamentais para a manutenção e funcionamento dos ciclos biogeoquímicos nesses ecossistemas (COTNER; BIDDANDA, 2002). 
O lançamento de efluentes doméstico e industrial sem tratamento adequado em mananciais, além do escoamento de fertilizantes agrícolas são responsáveis por aumentar rapidamente as concentrações de nutrientes fosfatados e nitrogenados na água (PAEL; PAUL, 2012). Esse contínuo e acelerado aumento do estado trófico em sistemas aquáticos impacta os ciclos biogeoquímicos e a dinâmica das comunidades microbianas (GLIBERT et al., 2016).

O enriquecimento das águas de reservatórios que abastecem a população é motivo de preocupação, pois este processo está associado ao crescimento de cianobactérias potencialmente produtoras de toxinas que trazem risco à saúde da população humana (MUNOZ et al., 2019; CHRISTENSEN; KHAN, 2020) As cianobactérias podem ser encontradas em reservatórios localizados em todo o território brasileiro e os gêneros mais frequentes e abundantes nesses ambientes são a Microcytis, Raphidiopsis $e$ Dolichospermum (SOARES et al., 2013; BARROS et al., 2019).

O filo Cyanobacteria abrange uma ampla diversidade de microrganismos procariontes capazes de realizar fotossíntese. Esse grupo é particularmente interessante, pois é frequentemente abordado em estudos que avaliam o fitoplâncton (SILVA et al., 2014; YANG et al., 2017; CAO et al., 2018; LIU et al., 2019 CUPERTINO et al., 2019) ou em pesquisas que focam no bacterioplâncton (ÁVILA et al., 2016; ZHAO et al., 2016; LI et al., 2019).

O bacterioplâncton também abrange outros grupos de microrganismos com uma ampla diversidade e variedade de metabolismos. O filo Proteobacteria é um dos mais abundantes entre as bactérias heterotróficas (MENEGHINE et al., 2017; LOPES et al 2018). Tanto as composições taxonômicas como as funcionais desses microrganismos parecem ser influenciadas pelas concentrações de nitrogênio disponíveis no ambiente (YANG et al 2019). Outros filos como, Actinobacteria, Bacteroidetes, Planctomycetes e Verrucomicrobia, são encontrados em ecossistemas aquáticos, e também apresentam potencial metabólico para participar de diferentes rotas do nitrogênio, incluindo desnitrificação, nitrificação, amonificação e até mesmo fixação de nitrogênio (MEDEIROS et al., 2016; ANDREOTE et al., 2018; DENG et al., 2020).

Na visão tradicional antiga do ciclo do nitrogênio o fitoplâncton $(>20 \mu \mathrm{m})$ era visto como o principal responsável pela assimilação de nitrogênio inorgânico, principalmente sob a forma de amônio (ZEHR; WARD, 2002). Com o surgimento de novas tecnologias e métodos, tais como microscopia de epifluorescencia (DALEY; HOBBIE, 1975), microscopia eletrônica (JOHNSON; SIRBURTH, 1982), citometria de fluxo (OLSON et 
al., 1985) e ferramentas moleculares (CALLIERI et al., 2012; CARAVATI et al., 2010; BATISTA; GIANI, 2019), houve um avanço em estudos sobre a fisiologia, ecologia e taxonomia de microrganismos (CALLIERI et al., 2007). Dessa forma, foram descobertos novos papéis da comunidade microbiana no metabolismo do nitrogênio em ecossistemas aquáticos.

Constatou-se que bactérias heterotróficas são abundantes em ambientes marinhos e em lagos oligotróficos, contribuindo significativamente para a assimilação de nitrogênio, podendo chegar até a 70\% (BRADLEY et al., 2010; FOUILLAND et al., 2007; TROTTET et al., 2016). Ressalta-se, entretanto, escassez de estudos que avaliem a diversidade de bactérias, bem como seu potencial funcional para o metabolismo do nitrogênio em reservatórios subtropicais.

Para quantificar taxas de assimilação de nitrogênio pela comunidade microbiana aquática em amostras ambientais, traçadores isotópicos $\mathrm{N}^{15}$ são frequentemente usados (BHAVYA et al., 2016; FILIPPINO; MULHOLLAND; BERNHARDT, 2011; MULHOLLAND; CAPONE, 1999).

No Brasil, através do uso de traçadores isotópicos, Cunha et al (2017) avaliaram a assimilação de nitrato e amônio nos reservatórios Itupararanga-SP e Barra Bonita. Em Itupararanga, as taxas de assimilação total de nitrogênio variam entre $<0,1$ a 2,1 $\mu$ mol.N.L $L^{-1} h^{-1}$, enquanto em Barra bonita variaram de 0,1 a $9,8 \mu$ mol.N.L ${ }^{-1} h^{-1}$. Ao longo de dois anos de amostragens não foi possível observar um padrão sazonal claro para a assimilação de nitrogênio e a parcela de contribuição de bactérias heterotróficas para esse processo não foi avaliada.

Para determinar as quantidades de ${ }^{15} \mathrm{NH}_{4}{ }^{+} \mathrm{e}^{15} \mathrm{NO}_{3}{ }^{-}$transformadas em nitrogênio orgânico, a amostra de água precisa ser filtrada em membranas de fibra de vidro para posterior análise elementar de nitrogênio e de espectrometria de massas (CAPONE, 2000). Nesses filtros ficam retidos organismos fitoplanctônicos de diferentes tamanhos e, também, bactérias heterotróficas (TROTTET et al., 2016). Se o fitoplâncton não for separado dos microrganismos menores, as taxas de assimilação de nitrogênio serão calculadas para toda a comunidade microbiana, incluindo bactérias. Por isso, para evitar superestimativas, estudos recomendam calcular taxas de assimilação de fitoplâncton e de bactérias separadamente. Para isso, processos de filtração podem ser usados selecionar a fração de tamanho microbiana a ser analisada (KIRCHMAN; WHEELER 1998; BRADLEY et al., 2010). No entanto, esse processo mecânico de separação de microrganismos, também apresenta limitações, como por exemplo não permite separar 
bactérias aderidas ao material orgânico. Devido a essa dificuldade, alguns estudos recorrem às técnicas de biologia molecular para detectar genes relacionados ao metabolismo do nitrogênio (ALLEN; WARD; SONG, 2005; WAWRIK et al 2012). Nesse aspecto, estudos metagenômicos são vantajosos, uma vez que permitem relacionar diversidade taxonômica com genes funcionais dos microrganismos envolvidos em vias metabólicas de interesse (GROSSART et al., 2020).

\section{Análise Metagenômica}

A metagenômica trouxe um grande avanço para a estudos que abrangem a ecologia microbiana, uma vez que através dessa análise é possível acessar a diversidade genômica com múltiplos níveis de resolução hierárquicos (ex: filo, classe, ordem, etc) sem que haja a necessidade de cultivar microrganismos em laboratório (HANDELSMAN, 2004). Isso é particularmente importante, pois grande parte dos microrganismos não são cultiváveis em laboratório devido a limitações de técnicas de cultivo existentes (HANDELSMAN, 2004).

Além disso, essa abordagem permite associar diversidade microbiana com processos metabólicos dos ciclos biogeoquímicos, tais como, fotossíntese, carboidratos, lipídios, ácidos nucléicos, fósforo, nitrogênio, enxofre, entre outros. Através dessa perspectiva estudos metagenômicos exploram diferenças ou semelhanças metabólicas e taxonômicas entre amostras, de acordo com a pergunta a ser respondida pelo estudo em questão (LLORENS-MARÈS et al., 2015; REIS et al., 2016).

As primeiras etapas básicas de um estudo metagenômico são os processos de amostragem e de extração de DNA. A amostragem deve ser realizada de acordo com o objetivo da pesquisa. Em ambientes aquáticos, frequentemente, a água é coletada considerando as escalas temporal e espacial e, posteriormente, filtrada em membranas apropriadas para reter os microrganismos de interesse (EILER et al., 2014). O processo de extração de DNA pode ser realizado através de protocolos ou ainda por kits específicos disponíveis no mercado. O DNA extraído deve representar toda a comunidade microbiana presente na amostra, além disso, deve apresentar alta qualidade e quantidade suficiente para a construção de bibliotecas metagenômicas e posterior sequenciamento (THOMAS; GILBERT; MEYER, 2012; KESHRI; MANKAZANA; MOMBA, 2015)

A escolha do método de sequenciamento é outra etapa fundamental em um estudo metagenômico. Atualmente, as tecnologias de equenciamento de alto desempenho (high 
throughput sequencing) tornaram-se amplamente difundidas por apresentarem custos mais acessíveis e serem capazes de gerar milhões de sequencias com diferentes tamanhos de reads (tamanhos de sequências) (HODKINSON; GRICE, 2015).

O método de sequenciamento da Illumina é baseado no processo de síntese de pequenos fragmentos de DNA (a serem sequenciados) com adaptadores ligados em suas extremidades (MARDIS, 2013). O processo de clivagem do DNA e de ligação dos adaptadores ocorre durante o preparo da biblioteca metagenômica (MARDIS, 2008). Posteriormente a esta etapa, os fragmentos de DNA com seus respectivos adaptadores são ancorados em uma placa sólida de vidro (flowcell), pareando-se com adaptadores complementares presentes na placa (MARDIS, 2013). A partir deste momento começa o processo de amplificação para a formação de clusters (milhares de cópias de fragmentos de DNA) (METZKER, 2010)

Após a formação dos clusters, dideosoxiribonucleotídeos, contendo fluoróforo clivável específico para cada uma das quatro bases nitrogenadas são adicionados a flowcell. Dideosoxiribonucleotídeos diferem-se de desoxiribonucleotíceos devido à ausência do grupo hidroxila (-OH) na posição 3' da ribose e, assim, os primeiros agem como terminadores de cadeia reversíveis, uma vez que bloqueiam a ligação de um nucleotídeo a outro temporariamente (MARDIS, 2008). Dessa forma, o sequenciamento ocorre pela síntese de uma nova fita, através da adição de uma base por vez e assim cada vez que uma base é incorporada à fita, um feixe de raio lazer é incidido para promover emissão de luz correspondente ao marcador fluorescente da base, tornando possível um registro de imagem (METZKER, 2010). Ao término do sequenciamento, são geradas milhões de reads que precisam ser analisadas com o auxílio de ferramentas da bioinformática e estatística (MANDE et al., 2012; SHARPTON, 2014).

Essas análises serão realizadas de acordo com os objetivos do estudo, que podem estar relacionados à caracterização da diversidade taxonômica e funcional microbiana ou à busca de genes específicos nos ciclos biogeoquímicos, ou a genes de virulência, resistência a antibióticos, e muitas outras possibilidades (MEDEIROS et al., 2016; SALLEM et al., 2019; SAMSON et., 2019; ZHOU et al., 2019). 


\section{OBJETIVOS}

\section{Objetivo geral}

O objetivo geral dessa pesquisa foi caracterizar as comunidades fitoplanctônicas e bacterianas, além de analisar os papéis desses microrganismos no metabolismo do nitrogênio, em reservatórios subtropicais, Lobo-SP e Itupararanga-SP.

\section{Objetivos específicos}

i. Caracterizar as comunidades bacterianas e fitoplanctônicas em diferentes períodos do ano, e avaliar suas relações com variáveis físico-químicas da água nos reservatórios do Lobo e Itupararanga.

ii. Determinar as taxas de assimilação de nitrogênio inorgânico (nitrato e amônio) pelo fitoplâncton e pela comunidade bacteriana nos reservatórios do Lobo e Itupararanga.

iii. Analisar a influência das características abióticas e bióticas de ambos os reservatórios, sobre as taxas de assimilação de nitrato e amônio.

iv. Caracterizar o perfil taxonômico e metabólico dos reservatórios e buscar genes envolvidos nas rotas metabólicas do metabolismo do nitrogênio através de análise metagenômica. 


\section{Referências}

ALLEN, A. E. et al. Diversity and Detection of Nitrate Assimilation Genes in Marine Bacteria. Applied and Environmental Microbiology, v. 67, n. 11, p. 5343-5348, 2001.

ALLEN, A. E.; WARD, B. B.; SONG, B. Characterization of diatom (Bacillariophyceae) nitrate reductase genes and their detection in marine phytoplankton communities. Journal of Phycology, v. 41, n. 1, p. 95-104, 2005.

ÁVILA, M. P. et al. Seasonality of freshwater bacterioplankton diversity in two tropical shallow lakes from the Brazilian Atlantic Forest. FEMS microbiology ecology, v. 93, n. 1, 2017.

BARROS, M. U. G et al. Environmental factors associated with toxic cyanobacterial blooms across 20 drinking water reservoirs in a semi-arid region of Brazil. Harmful algae, v. 86, p. 128$137,2019$.

BATISTA, A. M. M.; GIANI, A. Spatiotemporal variability of cyanobacterial community in a Brazilian oligomesotrophic reservoir: The picocyanobacterial dominance. Ecohydrology \& Hydrobiology, v. 19, n. 4, p. 566-576, 2019.

BERGES, J. A.; MULHOLLAND, M. R. Enzymes and Nitrogen Cycling. In: Capone, D.G.; BRONK, D.A.; MULHOLLAND, M.R.; CARPENTER, E.J. Nitrogen in the Marine Environment. 2 ed. Elsevier Inc., p. 1385-1444, 2008.

BHAVYA, P. S. et al. Nitrogen Uptake Dynamics in a Tropical Eutrophic Estuary (Cochin, India) and Adjacent Coastal Waters. Estuaries and Coasts, v. 39, n. 1, p. 54-67, 2016.

BRADLEY, P. B. et al. Inorganic and organic nitrogen uptake by phytoplankton and heterotrophic bacteria in the stratified Mid-Atlantic Bight. Estuarine, Coastal and Shelf Science, v. 88, n. 4, p. 429-441, 2010.

CALLIERI, C. et al. Photosynthetic characteristics and diversity of freshwater Synechococcus at two depths during different mixing conditions in a deep oligotrophic lake. Journal of Limnology, v. 66, n. 2, p. 81-89, 2007.

CALLIERI, C. et al. Picocyanobacterial community structure and space-time dynamics in the subalpine Lake Maggiore (N. Italy). Journal of Limnology, v. 71, n. 1, p. 95-103, 2012.

CANFIELD, D. E.; GLAZER, A. N.; FALKOWSKI, P. G. REVIEW. The Evolution and Future of Earth 's Nitrogen Cycle. Science, v. 330, p. 192-196, 2010.

CAO, J. et al. Succession of phytoplankton functional groups and their driving factors in a subtropical plateau lake. Science of the Total Environment, v. 631, p. 1127-1137, 2018.

CAPONE, D.G. The Marine Microbial Nitrogen Cycle. In: KIRCHMAN, D.L. Microbial Ecology of Oceans, 2th ed. Wiley-Liss Inc., 2000.

CARAVATI, E. et al. Picocyanobacterial assemblages in ultraoligotrophic Andean lakes reveal high regional microdiversity. Journal of Plankton Research, v. 32, n. 3, p. 357-366, 2010.

CHRISTENSEN, V. G.; KHAN, E. Freshwater neurotoxins and concerns for human, animal, and ecosystem health: A review of anatoxin-a and saxitoxin. Science of The Total Environment, v.736, p. 1-17, 2020. 
COTNER, B.; BIDDANDA, A. Small players, large role: microbial influence on biogeochemical processes in pelagic aquatic ecosystems. Ecosystems, v. 5, n. 2, p. 105-121, 2002.

CUNHA, D. G. F. et al. Uptake rates of ammonium and nitrate by phytoplankton communities in two eutrophic tropical reservoirs. International Review of Hydrobiology, v. 102, n. 5-6, p. 125 134, 2017.

CUPERTINO, A. et al. Phytoplankton assemblage composition as an environmental indicator in routine lentic monitoring: Taxonomic versus functional groups. Ecological indicators, v. 101, p. 522-532, 2019.

DALEY, R.J; HOBBIE, J.E. Direct counts of aquatic bacteria by a modified epifluorescence technique. Limnology and Oceanography, v. 20, p 875-882, 1975.

DODDS, W. K.; WHILES, M. R. Nitrogen, Sulfur, Phosphorus, and Other Nutrients. In: Freshwater Ecology: concepts and environmental applications of limnology. 2 ed. Elsevier Inc, 2010, p. 345-373.

EILER, A et al. Productivity and salinity structuring of the microplankton revealed by comparative freshwater metagenomics. Environmental microbiology, v. 16, n. 9, p. 2682-2698, 2014.

FASCHING, C. et al. Linking stream microbial community functional genes to dissolved organic matter and inorganic nutrients. Limnology and Oceanography, v. 65, p. S71-S87, 2020.

FILIPPINO, K. C.; MULHOLLAND, M. R.; BERNHARDT, P. W. Estuarine, Coastal and Shelf Science Nitrogen uptake and primary productivity rates in the Mid-Atlantic Bight ( MAB ). Estuarine, Coastal and Shelf Science, v. 91, n. 1, p. 13-23, 2011.

FOUILLAND, E. et al. Nitrogen uptake by heterotrophic bacteria and phytoplankton in Arctic surface waters. Journal of Plankton Research, v. 29, n. 4, p. 369-376, 2007.

GELDA, R. K. et al. Interannual variations in nitrification in a hypereutrophic urban lake: occurrences and implications. Water research, v. 34, n. 4, p. 1107-1118, 2000.

GLIBERT, P. M. et al. Pluses and minuses of ammonium and nitrate uptake and assimilation by phytoplankton and implications for productivity and community composition, with emphasis on nitrogen-enriched conditions. Limnology and Oceanography, v. 61, n. 1, p. 165-197, 2016.

GROSSART, Hans-Peter et al. Linking metagenomics to aquatic microbial ecology and biogeochemical cycles. Limnology and Oceanography, v. 65, p. S2-S20, 2020.

GUEDES, I. A. et al. Close link between harmful cyanobacterial dominance and associated bacterioplankton in a tropical eutrophic reservoir. Frontiers in microbiology, v. 9, p. 424, 2018.

HANDELSMAN, J. Metagenomics: application of genomics to uncultured microorganisms. Microbiology and Molecular Biology Reviews, v. 68, n. 4, p. 669-685, 2004.

HODKINSON, B. P.; GRICE, E. A. Next-generation sequencing: a review of technologies and tools for wound microbiome research. Advances in wound care, v. 4, n. 1, p. 50-58, 2015.

JENKINS, B. D.; ZEHR, J. P. Molecular Approaches to the Nitrogen Cycle. In: CAPONE, D.G.; BRONK, D.A.; MULHOLlAND, M.R.; CARPENTER, E.J. Nitrogen in the Marine Environment. 2 ed. Elsevier Inc., 2008. p. 1303-1344. 
JOHNSON, P.W; SIEBURTH, J.M.N. In situ morphology and occurrence of eukariotic phototrophs of bacterial size in the picoplankton of estuarine and oceanic waters. Journal of Phycology, v.8, p. 318-327, 1982.

KRAFT, B; STROUS, M; TEGETMEYER, H. E. Microbial nitrate respiration-genes, enzymes and environmental distribution. Journal of biotechnology, v. 155, n. 1, p. 104-117, 2011.

KESHRI, J.; MANKAZANA, B. B. J.; MOMBA, M. N. B. Profile of bacterial communities in South African mine-water samples using Illumina next-generation sequencing platform. Applied Microbiology and Biotechnology, v. 99, n. 7, p. 3233-3242, 2015.

KIRCHMAN, D. L.; WHEELER, P. A. Uptake of ammonium and nitrate by heterotrophic bacteria and phytoplankton in the sub-Arctic Pacific. Deep Sea Research, v. 45, p. 347-365, 1998.

LAVERMAN, A. M. et al. Potential nitrate removal in a coastal freshwater sediment (Haringvliet Lake, The Netherlands) and response to salinization. Water research, v. 41, n. 14, p. 3061-3068, 2007.

LI, H. et al. High-throughput DNA sequencing reveals the dominance of pico-and other filamentous cyanobacteria in an urban freshwater Lake. Science of The Total Environment, v. 661, p. 465-480, 2019.

LIU, Jinfu et al. Water-level fluctuations are key for phytoplankton taxonomic communities and functional groups in Poyang Lake. Ecological Indicators, v. 104, p. 470-478, 2019.

LLORENS-MARÈS et al. Connecting biodiversity and potential functional role in modern euxinic environments by microbial metagenomics. The ISME journal, v. 9, p. 1648-1661, 2015.

LOPES, F. Alvares Cardoso et al. Microbial community profile and water quality in a protected area of the Caatinga biome. PloS one, v. 11, n. 2, 2016.

MANDE, S. S.; MOHAMMED, M. H; GHOSH, T S. Classification of metagenomic sequences: methods and challenges. Briefings in bioinformatics, v. 13, n. 6, p. 669-681, 2012.

MARDIS, E. R. The impact of next-generation sequencing technology on genetics. Trends in genetics, v. 24, n. 3, p. 133-141, 2008.

MARDIS, E. R. Next-generation sequencing platforms. Annual review of analytical chemistry, v. 6, p. 287-303, 2013.

MEDEIROS, J. D. et al. Comparative metagenome of a stream impacted by the urbanization phenomenon. brazilian journal of microbiology, v. 47, n. 4, p. 835-845, 2016.

MENEGHINE, A. K. et al. Metagenomic analysis of soil and freshwater from zoo agricultural area with organic fertilization. PloS one, v. 12, n. 12, 2017.

METZKER, M. L. Sequencing technologies - the next generation. Nature reviews. Genetics, v. 11, n. 1, p. 31-46, 2010.

MULHOLLAND, M. R.; CAPONE, D. G. Nitrogen fixation, uptake and metabolism in natural and cultured populations of Trichodesmium spp. Marine Ecology Progress Series, v. 188, p. 33-49, 1999.

MULHOLlAND, M. R.; LOMAS, M. W. Nitrogen Uptake and Assimilation. In: Capone, D.G.; BRONK, D.A.; MULHOLLAND, M.R.; CARPENTER, E.J. Nitrogen in the Marine 
Environment. 2 ed. Elsevier Inc., 2008. p. 303-384.

MUNOZ, M et al. Degradation of widespread cyanotoxins with high impact in drinking water (microcystins, cylindrospermopsin, anatoxin-a and saxitoxin) by CWPO. Water research, v. 163, p. 114853, 2019.

NIZZOLI, D et al. Effect of organic enrichment and thermal regime on denitrification and dissimilatory nitrate reduction to ammonium (DNRA) in hypolimnetic sediments of two lowland lakes. Water research, v. 44, n. 9, p. 2715-2724, 2010.

PAERL, H. W.; PAUL, Valerie J. Climate change: links to global expansion of harmful cyanobacteria. Water research, v. 46, n. 5, p. 1349-1363, 2012.

POMEROY, Lawrence R. The ocean's food web, a changing paradigm. Bioscience, v. 24, n. 9, p. 499-504, 1974.

RASIGRAF, O. et al. Metagenomic potential for and diversity of N-cycle driving microorganisms in the Bothnian Sea sediment. Microbiology Open, v.6, v.4, p 1-13, 2017.

REIS, P. et al. Metagenomic signatures of a tropical mining-impacted stream reveal complex microbial and metabolic networks. Chemosphere, v. 161, p. 266-273, 2016.

RIEMANN, L.; FARNELID, H.; STEWARD, G. F. Nitrogenase genes in non-cyanobacterial plankton: Prevalence, diversity and regulation in marine waters. Aquatic Microbial Ecology, v. 61, n. 3, p. 235-247, 2010.

ROUMPEKA, D. D. et al. A review of bioinformatics tools for bio-prospecting from metagenomic sequence data. Frontiers in Genetics, v. 8, n. MAR, p. 1-10, 2017.

SALEEM, F. et al. Metagenomic profiling of fresh water lakes at different altitudes in Pakistan. Ecological Informatics, v. 51, p. 73-81, 2019.

SAMSON, R. et al. Metagenomic insights to understand transient influence of Yamuna River on taxonomic and functional aspects of bacterial and archaeal communities of River Ganges. Science of the Total Environment, v. 674, p. 288-299, 2019.

SHARPTON, T. J. An introduction to the analysis of shotgun metagenomic data. Frontiers in plant science, v. 5, p. 209, 2014.

SOARES, M. C. S. et al. Cyanobacterial dominance in Brazil: distribution and environmental preferences. Hydrobiologia, v. 717, n. 1, p. 1-12, 2013.

SILVA, L. H. S. et al. Drivers of phytoplankton, bacterioplankton, and zooplankton carbon biomass in tropical hydroelectric reservoirs. Limnologica, v. 48, p. 1-10, 2014.

STEIN, L. Y.; KLOTZ, M. G. The nitrogen cycle. Current Biology, v. 26, n. 3, p. R94-R98, 2016.

THOMAS, T.; GILBERT, J.; MEYER, F. Metagenomics - a guide from sampling to data analysis. Microbial Informatics and Experimentation, v. 2, n. 1, p. 3, 2012.

TROTTET, A. et al. Heterotrophic Bacteria Show Weak Competition for Nitrogen in Mediterranean Coastal Waters (Thau Lagoon) in Autumn. Microbial Ecology, v. 71, n. 2, p. 304314, 2016. 
ZHAO, D et al. Network analysis reveals seasonal variation of co-occurrence correlations between Cyanobacteria and other bacterioplankton. Science of the Total Environment, v. 573, p. 817-825, 2016.

ZEHR, J. P. et al. Nitrogenase gene diversity and microbial community structure: a cross-system comparison. Environ Microbiol, v. 5, n. 7, p. 539-554, 2003.

ZEHR, J. P. Nitrogen fixation by marine cyanobacteria. Trends in Microbiology, v. 19, n. 4, p. 162-173, 2011.

ZEHR, J. P.; KUDELA, R. M. Nitrogen cycle of the open ocean: from genes to ecosystems. Annual review of marine science, v. 3, p. 197-225, 2011.

ZEHR, J. P.; WARD, B. B. Nitrogen Cycling in the Ocean : New Perspectives on Processes and Paradigms. Applied and environmental microbiology, v. 68, n. 3, p. 1015-1024, 2002.

ZHOU, R. et al. Occurrence of human pathogenic bacteria carrying antibiotic resistance genes revealed by metagenomic approach: a case study from an aquatic environment. Journal of Environmental Sciences, v. 80, p. 248-256, 2019.

ZUMFT, W. G. Cell biology and molecular basis of denitrification. Microbiol. Mol. Biol. Rev., v. 61, n. 4, p. 533-616, 1997.

WAWRIK, B. et al. Assimilatory nitrate utilization by bacteria on the West Florida Shelf as determined by stable isotope probing and functional microarray analysis. FEMS Microbiology Ecology, v. 79, n. 2, p. 400-411, 2012.

WETZEL, R. G. Limnology: Lake and River Ecosystms.3th ed. Academic Press, 2001.

YANG, J. R. et al. Disturbance-induced phytoplankton regime shifts and recovery of cyanobacteria dominance in two subtropical reservoirs. Water research, v. 120, p. 52-63, 2017.

YANG, $\mathrm{Y}$ et al. Adaptive shifts of bacterioplankton communities in response to nitrogen enrichment in a highly polluted river. Environmental pollution, v. 245, p. 290-299, 2019. 
CAPÍTULO 1 - Spatiotemporal structure of phytoplankton, picophytoplankton and heterotrophic bacteria in subtropical reservoirs

\begin{abstract}
Phytoplankton (PHY), picophytoplankton (PPP) and heterotrophic bacteria (HB) are numerically dominant in the pelagic zone of aquatic ecosystems, being the base of aquatic food webs and playing key roles in biogeochemical processes. The development of new molecular technologies has increased the knowledge about the diversity of microorganisms but are still limited by not allowing the quantification of their biomass. Considering that the microbial communities of subtropical reservoirs are understudied, the main aim of this study was analysing the spatiotemporal structure and biomass of PHY, PPP, and HB communities from two meso-eutrophic subtropical reservoirs. PHY was analyzed by microscopic identification while PPP and HB were analyzed by cytometric fingerprints. Our results indicate that microbial communities vary spatiotemporally being mainly influenced by transparency, $\mathrm{pH}$, conductivity. Dissolved organic carbon (DOC) and dissolved inorganic nitrogen (DIN) were also responsible for shaping HB and PHY structures. PHY was the main component of biomass and was correlated with heterotrophic bacteria. The biomass of the PPP was very low, and phycocyanin rich picocyanobacteria (PC-rich Pcy) predominated or co-dominated with picoeukaryotes (Peuk). We conclude that microbial communities can be indicators of changes in the aquatic environment. In addition, the cytometric fingerprint revealed to be a cost-efficiency tool to targeting spatial and seasonal patterns in biomass and overall composition of microbial communities in these understudied ecosystems, contributing to increase the knowledge about microorganisms.
\end{abstract}

Key words: cytometric fingerprint, mesotrophic, picocyanobacteria 


\section{Introduction}

Phytoplankton (PHY) and heterotrophic bacteria (HB) play important biochemical and ecological roles in aquatic environments. Phytoplankton are the main primary producer in aquatic microbial food webs (Pomeroy, 1974), while heterotrophic bacteria are responsible for maintaining biogeochemical nutrient cycles (Biddanda, Ogdahl and Cotner, 2001).

PHY communities are widely studied in tropical reservoirs impacted by anthropic eutrophication (Silva et al., 2014; Santana, Weithoff and Ferragut, 2017; Cupertino et al., 2019) where the proliferation of potentially toxic cyanobacteria has been a common environmental issue (Sotero-Santos et al., 2006; Te and Gin, 2011; Casali et al 2017; Magalhães et al., 2019). The increase of cyanobacteria biomass causes degradation of water quality, being an issue of concern for drinking water treatment (Merel et al., 2013; Kumar et al., 2018) since the toxins produced by them represent a risk to human health (Loftin et al., 2016).

Although there are many studies on phytoplankton ecology, only a few studies have investigated small phytoplankton fractions (0.2-2 $\mu \mathrm{m}$; Sieburth et al. 1978), denominated picophytoplankton (PPP), in subtropical freshwater environments (Sarmento et al., 2008; Stenuite et al., 2009; Schiaffino et al., 2013). Optical microscopy is the most commonly used technique for phytoplankton analysis, but it limits the visualization of small cells from picophytoplankton and heterotrophic bacteria. With the emergence of new technologies, there was an advance in the knowledge of these microorganisms. High throughput sequencing of $16 \mathrm{~S}$ rRNA and 18S rRNA genes is widely used to analyze the structure of prokaryotic (Melo et al., 2018; Zhang et al., 2019) and eukaryotic (Alves-de-Souza et al., 2017; Kleinteich et al., 2020) microbial communities, respectively.

However, these analyses do not allow the quantification of microorganism's biomass. In the last years, flow cytometry has been widely applied to enumerate PPP, HB, and even viruses, (Lu et al., 2018; Yang et al., 2019), and biomass can be accessed with correction factors that estimate the amount of carbon in the cell (Feitosa et al., 2019). Spatiotemporal diversity of the bacterial and picophytoplankton community can be analyzed by cytometric characteristics that reflect cell morphology, size and pigments ( $\mathrm{Li}, 1997)$. By recognizing these patterns, the microorganisms can be classified, allowing 
to compare the cytometric fingerprint of many samples from different environments with low time-consuming (García et al., 2015).

The biomass and diversity of different phytoplankton fractions and bacterial communities are influenced by abiotic and biotic factors. Phytoplankton and picophytoplankton structures may change temporally and spatially, affected by temperature, water level, nutrient availability or by zooplankton grazing (Su et al., 2017; Bortolini et al., 2019; Liu et al., 2019). Recently, it has been found that the cytometric fingerprint of bacteria is related to $\mathrm{pH}$, hardness, dissolved organic carbon, and also with predation (Quiroga et al., 2017, Segovia et al., 2018). It is also known that heterotrophic bacteria can interact with phytoplankton and picophytoplankton (Guedes et a., 2018). These three communities are abundant in tropical environments and are fundamental to the production and transfer of carbon in aquatic food webs (Sarmento, 2012). However, compared to temperate systems, there are still few studies about the structure and dynamics of these microorganisms in tropical environments. The main differences between these environments are related to primary productivity, which is higher in tropical environments due to the higher temperatures and solar radiation, and a low annual variation (Lewis, 1987; Sarmento, 2012).

Many of tropical environments are being subjected to intense changes caused by the excessive input of nutrients. So, studies on water quality and biological communities in tropical mesotrophic reservoirs are important for future developing mitigation and preservation strategies for these environments. The aim of this study was to investigate the spatial and temporal dynamics of phytoplankton, picophytoplankton and heterotrophic bacteria biomass in two subtropical mesotrophic reservoirs. We also analyzed the influence of environmental factors on these microbial communities.

\section{Material and Methods}

\section{Study area and sampling}

The Lobo and Itupararanga reservoirs are located in the state of São Paulo, Southeast of Brazil (Figure 1-1). According to Köopen classification, this region presents climate Cwa with a distinct dry season (April - September) and wet season (October March) (Beghelli et al., 2016). The Itupararanga reservoir was originally built in 1912 for electricity generation but is currently used for public water supplying (approximately 850.000 people). This reservoir has an area of $20.9 \mathrm{Km}^{2}$, a volume of 286 million $\mathrm{m}^{3}$ and 
a hydraulic retention time ranging from 120 to 390 days, depending on the rainfall pattern (Cunha and Calijuri, 2011; Beghelli et al., 2016). The Lobo reservoir, also known as Broa, with an area of $5.8 \mathrm{~km}^{2}, 22$ million $\mathrm{m}^{3}$ volume and low hydraulic retention time (20-40 days), has been studied for at least 48 years (Frascareli et al 2018). This reservoir is used for electricity generation, (approximately $2000 \mathrm{~kW}$ ), and also contributes to the social and economic development of the surrounding population (Periotto and Tundisi, 2013).

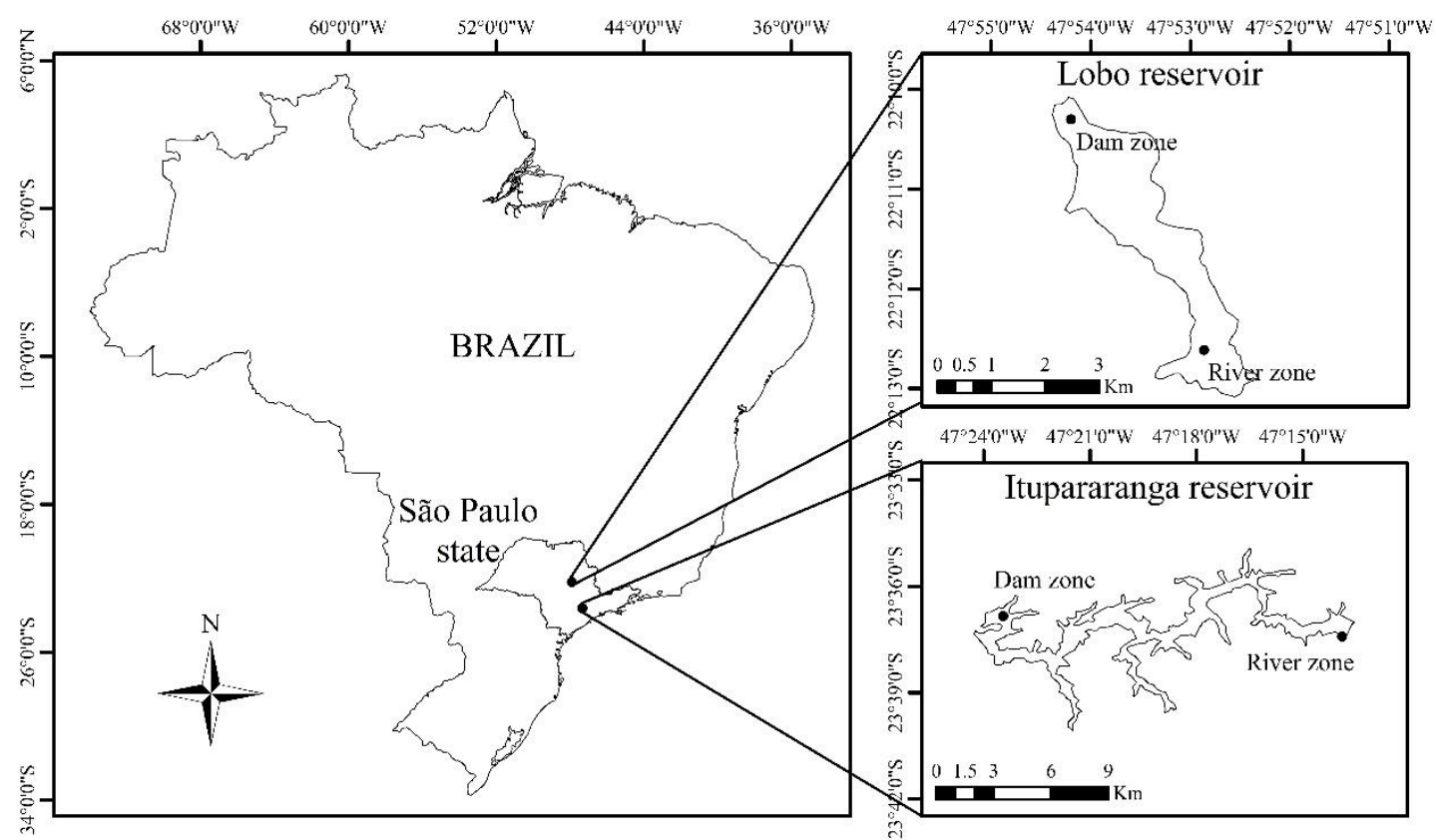

Figure 1-1. Map of the studied reservoirs (Lobo and Itupararanga) with the locations of sampling sites, river zone and zone close to the dam.

In both reservoirs, two sample sites were established, one near to the river entrance, called the River zone, (Itupararanga: 2337'24.8"S 47²3'53.4"W; Lobo: $22^{\circ} 12^{\prime} 36.9^{\prime \prime} \mathrm{S} 47^{\circ} 52^{\prime} 52.8^{\prime \prime} \mathrm{W}$ ) and the other close to the dam (Itupararanga: $23^{\circ} 36^{\prime} 50.7^{\prime \prime} \mathrm{S}$ $47^{\circ} 23^{\prime} 27.3^{\prime \prime} \mathrm{W}$; Lobo: $\left.22^{\circ} 10^{\prime} 18.5^{\prime \prime S} \quad 47^{\circ} 54^{\prime} 11.2^{\prime \prime} \mathrm{W}\right)$. For determining the Photosynthetically Active Radiation (PAR), a radiometer (Quanta-Meter LI-COR, 400$700 \mathrm{~nm}$ ) was used. Water samples were collected with Van Dorn bottles at four depths (100, 50, 1\% PAR and aphotic zone) in February (summer), May (autumn), August (winter), October (spring) of 2017 and January (summer) of 2018. In this study, a total of 72 samples were obtained since there was no aphotic depth in the river zones of Lobo (all sample periods) and in Itupararanga (October, 2017). 
For the phytoplankton analysis, the water samples collected in the field were immediately preserved with acetic Lugol solution. Samples for quantifying heterotrophic bacteria and picophytoplankton were fixed with formaldehyde buffered with borax (final concentration equals to $1 \%$ ), frozen in nitrogen liquid and stored at $-80{ }^{\circ} \mathrm{C}$ until the analysis.

\section{Environmental parameters}

Water temperature, $\mathrm{pH}$, conductivity and dissolved oxygen (DO) were measured in situ with a multiparameter probe (HANNA®, model HI 9829) at intervals of $0.5 \mathrm{~m}$ to the water column, and the average results are presented (Table 1-1). Water transparency was measured using a Secchi disk and the depth of the euphotic zone (Zeu) was determined as $1 \%$ of PAR.

For each sample, from 0.2 to $0.5 \mathrm{~L}$ of water were filtered through fiberglass filters Macherey-Nagel GF-3. The filters were used for chlorophyll analysis after extraction with ethanol 80\% v/v (Nusch, 1980) and the filtered water was taken for dissolved nutrient analysis. Nitrate $\left(\mathrm{N}^{-\mathrm{NO}_{3}}{ }^{-}\right)$, nitrite $\left(\mathrm{N}-\mathrm{NO}_{2}{ }^{-}\right)$and soluble reactive phosphorus (SRP) were determined by colorimetric methods proposed in APHA (2005). Ammonium $\left(\mathrm{N}_{-} \mathrm{NH}_{4}{ }^{+}\right)$ analyses were performed according to Koroleff (1976) and ammonium, nitrate and nitrite concentrations were summed to estimate dissolved inorganic nitrogen (DIN). Dissolved organic carbon (DOC) was analyzed by combustion method with a total organic carbon analyzer (Shimadzu SSM 5000). For analyzing total suspended solids (TSS), Whatman® $\mathrm{GF} / \mathrm{C}$ filters were used and the concentrations were determined by gravimetric method (APHA, 2005).

Total phosphorus (TP) and total Kjeldahl nitrogen (TKN) were analyzed with unfiltered water according to APHA (2005). The sum of TKN, nitrate and nitrite concentrations were used to estimate total nitrogen $(\mathrm{TN})$ and the TN:TP molar ratios were calculated.

The trophic state index of the sampled sites was calculated considering the annual geometric means of total phosphorus and chlorophyll (Cunha, Calijuri and Lamparelli 2013).

Community biomass analyses

Phytoplankton (PHY) quantification was performed in sedimentation chambers (Uthermol, 1958) using an inverted microscope at $400 \times$ magnification. The mean cell 
volume $\left(\mu \mathrm{m}^{3}\right)$ of species was estimated by geometric approximations (Hillebrand et al., 1999; Sun and Liu, 2003) measuring 20 individuals from each taxon or was obtained from specialized literature for species with relative abundance $<10 \%$.

The carbon content of PHY species was determined by the equation $\mathrm{C}=\mathrm{a} \cdot \mathrm{V}^{\mathrm{b}}$, where, $\mathrm{C}=$ carbon in, $\mu \mathrm{g} \mathrm{C}$ cell $^{-1} ; \mathrm{a}=0.1204 ; \mathrm{b}=1.051$; and $\mathrm{V}=$ species volume in $\mu \mathrm{m}^{3}$ (Rocha and Duncan, 1985). To estimate total PHY biomass $\left(\mu \mathrm{g} \mathrm{C} \mathrm{L}^{-1}\right)$ in the samples, the carbon content calculated for each species was multiplied by the population abundance (org $\mathrm{mL}^{-1}$ ).

From two subsamples, picophytoplankton (PPP) and heterotrophic bacteria (HB) abundances were determined separately with a FACSCalibur cytometer. For HB quantification, the SYTO-13 stain (Molecular Probes; $2.5 \mu \mathrm{mol} \mathrm{L}{ }^{-1}$ final concentration) and fluorescent beads $(1 \mu \mathrm{m}$, Fluoresbrite carboxylate microspheres, Polysciences Inc., Warrington, PA, U.S.A.) were added to the samples as recommended in Sarmento et al (2008). HB were detected by their signature in plots of side scatter (SSC) versus FL1 (green fluorescence) (Sarmento et al 2008). For PPP analysis, only fluorescent beads were added to the samples, and the cells were detected on cytograms, plotting SSC versus FL3 (blue laser dependent red fluorescence). Through the PPP cytograms, we were able to distinguish eukaryote picophytoplankton (Peuk) and two types of picocyanobacteria (Pcy): phycoerythrin rich cells (PE-rich Pcy) and phycocyanin rich cells (PC-rich Pcy).

To estimate $\mathrm{HB}$ and PPP biomass $\left(\mu \mathrm{g} \mathrm{C} \mathrm{L}^{-1}\right)$ in each sample, correction factors described in previous studies were used (Stenuite et al., 2009; Feitosa et al., 2019). HB, Pcy and Peuk abundance were multiplied by the correction factors of $20 \mathrm{fg} \mathrm{C}$ per cell (Lee and Fuhrman, 1987), 103 fg C per cell (Zubkov et al., 1998) and $530 \mathrm{fg} \mathrm{C}$ per cell (Worden, Nolan and Palenik, 2004), respectively. Total PPP biomass was obtained by adding Pcy and Peuk.

\section{Cytometric fingerprint}

To analyze the cytometric fingerprint of PPP and HB we used the flowDiv pipeline (Wanderley et al., 2015, 2019) developed in language R (R Development Core Team, 2016). With flowDiv, the cytograms of each sample were pairwise compared and two Bray-Curtis dissimilarity matrices were generated, one for PPP and another for HB. These matrices were used in the statistical analyses. 


\section{Statistical analyses}

The normality of environmental and biological data was assessed by the ShapiroWilk test. Differences over time, between the sites in relation to environmental variables and biomass of the communities, were evaluated with the non-parametric Kruskal-Wallis test. Spearman's rank correlations were used to determine the relationships between biomass communities and between environmental factors. A Bray-Curtis PHY dissimilarity matrix was calculated based on the data from species biomass, while the HB and PPP matrices were obtained by the cytometric differences analyzed with the FlowDiv package. The relationships between the dissimilarity matrices were analyzed in pairs with Mantel test with 10,000 permutations. Non-metric multidimensional scaling (NMDS) was used to visualize the community structure. The homogeneity of multivariate variances within groups (beta dispersion) was analyzed and statistical differences in the community structure between reservoirs, seasons, sites and depths were tested with permutational multivariate analysis of variance (PERMANOVA).

The influence of environmental variables on biological communities was evaluated with distance-based redundancy analysis (dbRDA) (Legendre and Legendre, 1998). To perform this analysis, abiotic data were $\log (\mathrm{x}+1)$ transformed, except $\mathrm{pH}$. Variance inflation factors (VIF) was used to identify the collinearity between environmental variables, and those that presented VIF $>2.5$ were removed from dbRDA (Legendre and Legendre, 1998). We tested the significance of dbRDA models with ANOVA and significant variables were analyzed with the "ordistep" function from the vegan package (Oksanen et al., 2015) in R language (Legendre and Legendre, 1998). All analyses presented here were conducted in $\mathrm{R}$ version 3.6.2. Figures were drawn using the R package ggplot2 (Wickham, 2009) and software Origin, version 2019 (OriginLab Corporation, Northampton, MA, USA).

\section{Results}

\section{Environmental characterization}

During the sampling period, the physicochemical characteristics of the water varied mainly in time scale and among sampling sites (Table 1-1). However, no differences were observed between different depths. In both reservoirs, Zeu and transparency were greater within the dam. The TSS concentrations have shown a spatial 
and temporal difference in Itupararanga ( $\mathrm{p}<0.001$ ), however in the Lobo reservoir, no spatial differences were found.

The lowest water temperatures occurred in August $\left(15.4{ }^{\circ} \mathrm{C}\right.$ in Itupararanga and $18.0{ }^{\circ} \mathrm{C}$ in Lobo) and the highest in February $\left(27.8^{\circ} \mathrm{C}\right.$ in Itupararanga and $28.8{ }^{\circ} \mathrm{C}$ in Lobo) (Table 1-1; Figure S1-1, S1-2). In some periods it was possible to observe an anoxic zone in the dam of Itupararanga (Feb/2017, Oct/2017 and Jan/2018) (Figure S11) and of Lobo (Feb/2017 and Oct/ 017) (Figure S1-2). The lowest mean concentration of dissolved oxygen $\left(3.23 \pm 0.23 \mathrm{mg} \mathrm{L}^{-1}\right)$ (Table 1-1) was observed in May in the Itupararanga river region. Conductivity values ranged from 63.0 to $101.0 \mu \mathrm{S} \mathrm{cm}^{-1}$ and from 13 to $36 \mu \mathrm{S} \mathrm{cm} \mathrm{cm}^{-1}$ in Itupararanga and Lobo, respectively. The $\mathrm{pH}$ exhibited significant differences over time $(\mathrm{p}=0.003)$, with lower average $\mathrm{pH}$ obtained in Lobo $($ Dam $=6.5$; River zone $=6.6)$ compared to Itupararanga $($ Dam $=7.0$; River zone $=7.5)$.

In Itupararanga the DIN, nitrate and TP concentrations were significantly higher in the river zone $(\mathrm{p}<0.001)$. The DIN and nitrate concentrations were approximately 2 times higher (DIN ranging from 768.1 to $1162.8 \mu \mathrm{g} \mathrm{L}^{-1}$ and nitrate from 703.3 to 1063.3 $\mu \mathrm{g} \mathrm{L}^{-1}$ ). In addition, DIN was mainly composed of nitrate. The average TP concentration in the Itupararanga river zone $\left(49.5 \mu \mathrm{g} \mathrm{L}^{-1}\right)$ was about 3.5 times higher than the concentration in the dam $\left(14.3 \mathrm{ug} \mathrm{L}^{-1}\right)$ (Table 1-1). The nitrite and SRP concentrations were almost always below $5 \mu \mathrm{g} \mathrm{L}^{-1}$ and $6.5 \mu \mathrm{g} \mathrm{L} \mathrm{L}^{-1}$, respectively. Also, the values were frequently below the detection limit of the equipment $\left(0.5 \mu \mathrm{g} \mathrm{L}^{-1}\right.$ for nitrite and $0.7 \mu \mathrm{g} \mathrm{\textrm {L } ^ { - }}$ ${ }^{1}$ for RSP). Ammonium availability varied significantly throughout the months of the study. The highest concentrations were observed in the Itupararanga $(144.8 \mu \mathrm{g} \mathrm{L})$ and Lobo $\left(93.4 \mu \mathrm{g} \mathrm{L}^{-1}\right)$ dams.

Regarding the NP ratios, the lowest average ratio observed occurred in the Itupararanga river zone $($ mean $=48.8)$ in October/2017, where the lowest observed ratio was also observed $(\min =30.9)$. DOC concentrations were similar in the two reservoirs, ranging from 2.9 to $7.7 \mathrm{mg} \mathrm{L}^{-1}$ in Itupararanga and from 3.1 to $6.3 \mathrm{mg} \mathrm{L}^{-1}$ in Lobo. TSS values varied significantly $(\mathrm{p}=0.001)$ between the Itupararanga sites with the highest concentrations in the river zone (mean $=8.1 \mathrm{mg} \mathrm{L}^{-1}$ ). Differences in chlorophyll concentrations were observed between reservoirs. In the Lobo reservoir, the average chlorophyll concentrations were $11.0 \mu \mathrm{g} \mathrm{L}^{-1}$ (river zone) and $12.4 \mu \mathrm{g} \mathrm{L}^{-1}$ (Dam), while Ituparararanga presented values of $30.5 \mu \mathrm{g} \mathrm{L}^{-1}$ (river zone) and $21.9 \mu \mathrm{g} \mathrm{L}^{-1}$ (Dam). According to the trophic state index calculated by the annual geometric mean, the 
reservoirs were classified as mesotrophic, except river zone of Itupararanga that was classified as eutrophic.

Table 1-1. Mean values and range of the environmental parameters measured in the Itupararanga and Lobo reservoirs

\begin{tabular}{|c|c|c|c|c|}
\hline \multirow[b]{2}{*}{ Variables } & \multicolumn{2}{|c|}{ Itupararanga } & \multicolumn{2}{|c|}{ Lobo } \\
\hline & $\begin{array}{l}\text { River zone } \\
(\mathrm{n}=19)\end{array}$ & $\begin{array}{l}\text { Dam } \\
(\mathrm{n}=20)\end{array}$ & $\begin{array}{l}\text { River zone } \\
\quad(n=15)\end{array}$ & $\begin{array}{l}\text { Dam } \\
(\mathrm{n}=20)\end{array}$ \\
\hline $\mathbf{Z}_{\mathrm{eu}}(\mathbf{m})$ & $\begin{array}{c}2.5 \\
(2.0-3.0)\end{array}$ & $\begin{array}{c}5.5 \\
(4.5-7.0)\end{array}$ & $\begin{array}{c}2.1 \\
(2.0-2.5)\end{array}$ & $\begin{array}{c}3.6 \\
(2.5-5.0)\end{array}$ \\
\hline Transparency（m) & $\begin{array}{c}1.3 \\
(0.9-1.6)\end{array}$ & $\begin{array}{c}1.5 \\
(1.2-1.9)\end{array}$ & $\begin{array}{c}1.1 \\
(1.0-1.2)\end{array}$ & $\begin{array}{c}1.8 \\
(1.2-2.3)\end{array}$ \\
\hline Temperature $\left({ }^{\circ} \mathrm{C}\right)$ & $\begin{array}{c}21.1 \\
(15.4-27.8)\end{array}$ & $\begin{array}{c}22.2 \\
(17.0-27.5)\end{array}$ & $\begin{array}{c}22.6 \\
(18.2-28.8)\end{array}$ & $\begin{array}{c}23.1 \\
(18.0-28.8)\end{array}$ \\
\hline pH & $\begin{array}{c}7.00 \\
(6.4-9.0)\end{array}$ & $\begin{array}{c}7.5 \\
(6.5-9.1)\end{array}$ & $\begin{array}{c}6.6 \\
(5.9-8.7)\end{array}$ & $\begin{array}{c}6.5 \\
(5.8-7.8)\end{array}$ \\
\hline Cond. $\left(\mu \mathrm{S} \mathrm{cm}\right.$ cm $\left.^{-1}\right)$ & $\begin{array}{c}82.5 \\
(65.0-101.0)\end{array}$ & $\begin{array}{c}68.4 \\
(63.0-76.0)\end{array}$ & $19.5(15.0-36.0)$ & $18.1(13.0-34.0$ \\
\hline DO $\left(\mathrm{mg} \mathrm{L}^{-1}\right)$ & $\begin{array}{c}5.9 \\
(3.1-9.4)\end{array}$ & $\begin{array}{c}6.5 \\
(0.0-8.6)\end{array}$ & $\begin{array}{c}6.3 \\
(4.5-8.2)\end{array}$ & $\begin{array}{c}6.2 \\
(0.0-9.1)\end{array}$ \\
\hline $\mathbf{T N}\left(\mu \mathrm{g} \mathbf{L}^{-1}\right)$ & $\begin{array}{c}1007.6 \\
(806.7-1336.2)\end{array}$ & $\begin{array}{c}476.4 \\
(320.5-668.4)\end{array}$ & $\begin{array}{c}801.8 \\
(608.4-1051.3)\end{array}$ & $\begin{array}{c}788.1 \\
(500.8-1445.9)\end{array}$ \\
\hline TKN $\left(\mu g^{-1}\right)$ & $\begin{array}{c}163.5 \\
(4.7-433.5)\end{array}$ & $\begin{array}{c}114.9 \\
(0.0-329.9)\end{array}$ & $\begin{array}{c}133.8 \\
(17.3-341.4)\end{array}$ & $\begin{array}{c}191.2 \\
(0.0-782.6)\end{array}$ \\
\hline $\operatorname{DIN}\left(\mu \mathrm{g} \mathrm{L}^{-1}\right)$ & $\begin{array}{c}880.5 \\
(768.1-1162.8)\end{array}$ & $\begin{array}{c}399.9 \\
(320.0-561.4)\end{array}$ & $\begin{array}{c}678.5( \\
591.1-774.2)\end{array}$ & $\begin{array}{c}616.5 \\
(423.0-1473.2)\end{array}$ \\
\hline $\mathrm{NO}_{2}^{-}\left(\mu \mathrm{g} \mathrm{L}^{-1}\right)$ & $\begin{array}{c}5.3 \\
\text { (nd-13.3) }\end{array}$ & $\begin{array}{c}0.6 \\
\text { (nd-2.2) }\end{array}$ & $\begin{array}{c}3.1 \\
\text { (nd-5.0) }\end{array}$ & $\begin{array}{c}2.2 \\
(0.4-3.9)\end{array}$ \\
\hline $\mathrm{NO}_{3}^{-}\left(\mu \mathrm{g} \mathrm{L}^{-1}\right)$ & $\begin{array}{c}838.8 \\
(703.3-1063.3)\end{array}$ & $\begin{array}{c}360.8 \\
(320.0-416.7)\end{array}$ & $\begin{array}{c}664.9 \\
(586.7-753.3\end{array}$ & $\begin{array}{c}594.7 \\
(400.0-1443.3)\end{array}$ \\
\hline $\mathrm{NH}_{4}^{+}\left(\mu \mathrm{g} \mathrm{L}^{-1}\right)$ & $\begin{array}{c}36.4 \\
\text { (nd-98.6) }\end{array}$ & $\begin{array}{c}38.4 \\
\text { (nd-144.8) }\end{array}$ & $\begin{array}{c}11.0 \\
\text { (nd-35.1) }\end{array}$ & $\begin{array}{c}19.6 \\
\text { (nd-93.4) }\end{array}$ \\
\hline $\mathbf{T P}\left(\mu g \mathrm{~L}^{-1}\right)$ & $\begin{array}{c}49.5 \\
(25.2-86.6)\end{array}$ & $\begin{array}{c}14.3 \\
(8.9-28.0)\end{array}$ & $\begin{array}{c}26.8 \\
(14.2-38.6)\end{array}$ & $\begin{array}{c}17.7 \\
(10.9-23.1)\end{array}$ \\
\hline $\operatorname{RSP}\left(\mu \mathrm{g} \mathrm{L}^{-1}\right)$ & $\begin{array}{c}6.5 \\
(3.3-27.5)\end{array}$ & $\begin{array}{c}1.0 \\
\text { (nd-4.5) }\end{array}$ & $\begin{array}{c}2.8 \\
\text { (nd-4.0) }\end{array}$ & $\begin{array}{c}1.6 \\
\text { (nd-3.9) }\end{array}$ \\
\hline DOC $\left(m g ~ L^{-1}\right)$ & $\begin{array}{c}5.0 \\
(2.9-7.7)\end{array}$ & $\begin{array}{c}4.1 \\
(3.5-4.8)\end{array}$ & $\begin{array}{c}4.9 \\
(3.5-6.3)\end{array}$ & $\begin{array}{c}4.3 \\
(3.1-5.9)\end{array}$ \\
\hline TSS (mg L $\left.\mathbf{L}^{-1}\right)$ & $\begin{array}{c}8.1 \\
(5.6-17.4)\end{array}$ & $\begin{array}{c}5.5 \\
(1.9-9.7)\end{array}$ & $\begin{array}{c}5.3 \\
(2.3-11.3)\end{array}$ & $\begin{array}{c}4.1 \\
(1.9-10.2)\end{array}$ \\
\hline TN:TP & $\begin{array}{c}48.8 \\
(30.9-97.3)\end{array}$ & $\begin{array}{c}81.6 \\
(31.5-167.2)\end{array}$ & $\begin{array}{c}71.7 \\
(44.3-137.9)\end{array}$ & $\begin{array}{c}104.3 \\
(51.9-242.1)\end{array}$ \\
\hline $\begin{array}{l}\text { Chlorophyll } a\left(\mu g \mathrm{~L}^{-}\right. \\
\left.{ }^{1}\right)\end{array}$ & $\begin{array}{c}30.5 \\
(2.0-95.0)\end{array}$ & $\begin{array}{c}21.9 \\
(15.1-35.8)\end{array}$ & $\begin{array}{c}11.0 \\
(3.9-30.1)\end{array}$ & $\begin{array}{c}12.4 \\
(1.6-27.3)\end{array}$ \\
\hline Trophic state & Eutrophic & Mesotrophic & Mesotrophic & Mesotrophic \\
\hline
\end{tabular}




\section{Communities biomass}

The PHY biomass was much higher in comparison to PPP ( $\mathrm{p}<0.001)$ and HB $(\mathrm{p}<0.001)$ (Figure 1-2) and greater in Itupararanga than in Lobo. The highest values of PHY biomass in Itupararanga occurred in the river zone during the month of October $\left(\right.$ mean $\left.=4316.9 \pm 2659.7 \mu \mathrm{g} \mathrm{C} \mathrm{L}^{-1}\right)$ and the lowest values were observed in May (mean = $\left.103.6 \pm 32.73 \mu \mathrm{g} \mathrm{C} \mathrm{L}^{-1}\right)$. PHY biomass showed a significant temporal difference ( $\mathrm{p}=$ 0.001) in Itupararanga, while in Lobo, there was a difference between the sampling sites $(\mathrm{p}=0.037)$.

(a)

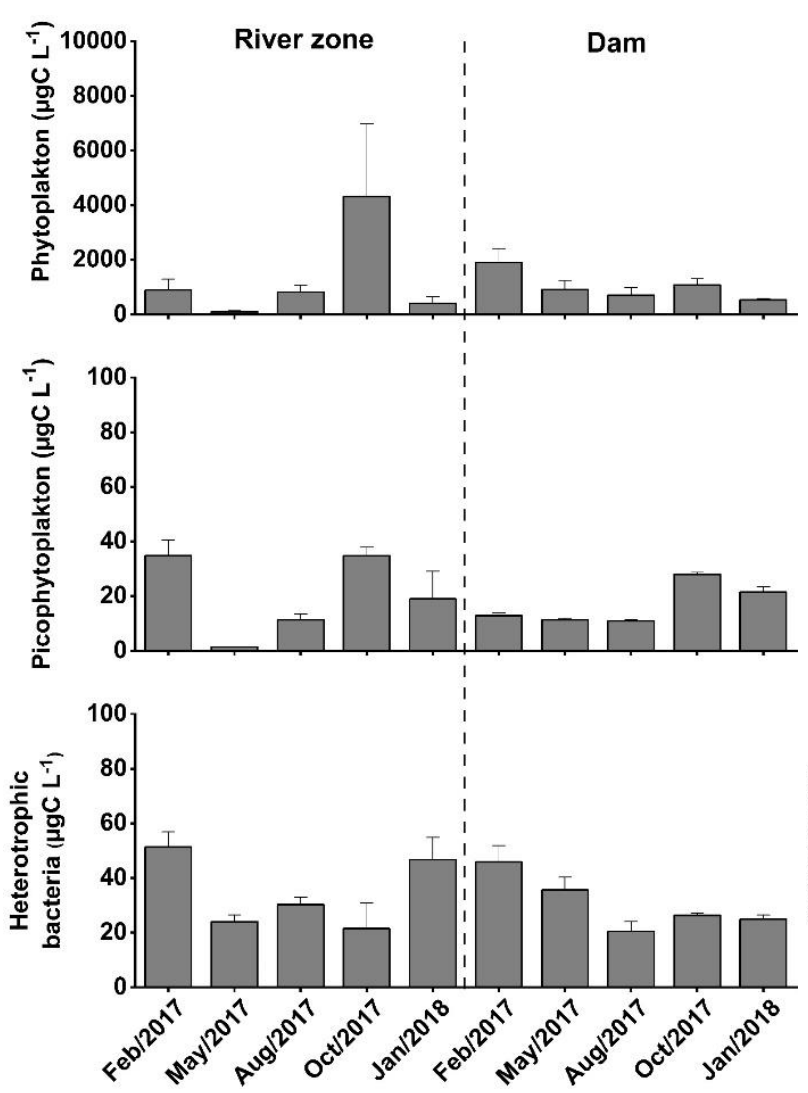

(b)

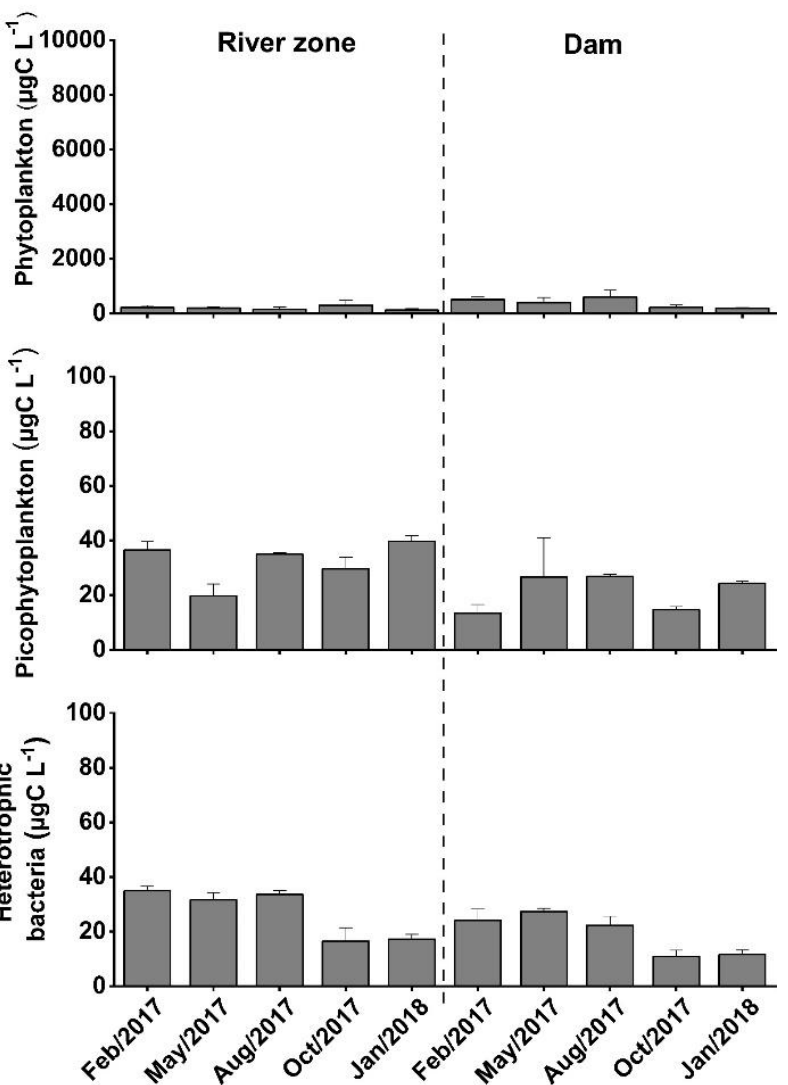

Figure 1-2. Carbon biomass of phytoplankton, picophytoplankton and heterotrophic bacteria: (a) Itupararanga reservoir (b) Lobo reservoir.

The same patterns were observed for the PPP. A temporal difference was observed in Itupararanga ( $\mathrm{p}<0.001$ ), while the PPP biomass in the Lobo reservoir showed a horizontal spatial difference. During the sampling periods, there was an alternation of 
predominance and co-dominance between Peuk and Pcy (Figure S1-3). However, our results suggest that the latter had predominance in most samples, contributing up to $82 \%$ in the total PPP biomass. It was also observed that the Lobo and Itupararanga reservoirs present low PE-rich Pcy biomass and greater contribution of PC-rich Pcy (Figure S1-3).

The values of $\mathrm{HB}$ biomass varied from 20.4 to $51.3 \mu \mathrm{g} \mathrm{C} \mathrm{L}^{-1}$ in Itupararanga and from 10.9 to $34.9 \mu \mathrm{g} \mathrm{C} \mathrm{L}^{-1}$ in Lobo (Table 1-2). Spatial and temporal differences were observed in the two reservoirs. In addition, we also observed that the HB biomass correlates with the PHY biomass $(r=0.32, \mathrm{p}=0.005)$.

Table 1-2. Mean values and range of microbial communities biomass in the river zone and dam of Itupararanga and Lobo reservoirs.

\begin{tabular}{lcccc}
\hline & \multicolumn{2}{c}{ Itupararanga } & \multicolumn{2}{c}{ Lobo } \\
\hline & $\begin{array}{c}\text { River zone } \\
(\mathrm{n}=19)\end{array}$ & $\begin{array}{c}\text { Dam } \\
(\mathrm{n}=20)\end{array}$ & $\begin{array}{c}\text { River zone } \\
(\mathrm{n}=15)\end{array}$ & $\begin{array}{c}\text { Dam } \\
(\mathrm{n}=20)\end{array}$ \\
\hline PHY & 1146.8 & 1025.9 & 195.1 & 382.1 \\
& $(50.7-6024.9)$ & $(462.1-2494.9)$ & $(59.1-496.8)$ & $(138.9-949.5)$ \\
PPP & 19.5 & 17.1 & 32.1 & 21.1 \\
& $(1.3-39.8)$ & $(10.4-28.8)$ & $(16.3-41.8)$ & $(9.4-44.5)$ \\
Total Pcy & 12.1 & 10.5 & 17.9 & 10.8 \\
& $(0.7-26.8)$ & $(2.2-24.4)$ & $(4.8-28.8)$ & $(3.0-19.5)$ \\
Pcy PC-rich & 12.0 & 8.5 & 17.8 & 10.7 \\
& $(0.6-26.8)$ & $(1.7-19.6)$ & $(4.7-28.7)$ & $(2.9-19.3)$ \\
Pcy PE-rich & 0.1 & 2.0 & 0.1 & 0.1 \\
& $(0.0-0.3)$ & $(0.5-4.9)$ & $(0.1-0.2)$ & $(0.0-0.3)$ \\
Peuk & 7.4 & 6.6 & 14.2 & 10.3 \\
& $(0.6-16.5)$ & $(3.9-9.3)$ & $(5.4-19.0)$ & $(4.3-25.0)$ \\
HB & 35.4 & 30.6 & 26.8 & 19.2 \\
& $(11.2-56.2)$ & $(15.2-54.3)$ & $(11.6-36.6)$ & $(7.8-30.3)$ \\
\hline
\end{tabular}

PHY phytoplankton; PPP picophytoplankton, Pcy picocyanobacterial; PC phycocyanin; PE phycoerythrin; HB heterotrophic bacteria.

\section{Spatiotemporal patterns on communities structure}

We used PERMANOVA test to assess the influence of spatial and temporal patterns on the PHY, PPP and HB communities. The beta dispersion of PPP was significant in season $(\mathrm{F}=12.26, \mathrm{p}<0.001)$, thus PERMANOVA was not applied for PPP, however, the NMDS indicates grouping of seasonal samples, especially for January and August (Figure 1-3.b).

It has been found that PHY differs significantly between reservoirs, over seasons and between sites (Table 1-3). These differences can be seen by NMDS (Figure 1-3.a), and we can see a clear PHY separation between reservoirs, and between sampling sites, 
especially in Itupararanga. HB also differed mainly between reservoirs and between sampling sites (Table 1-3 and Figure 1-3.c). In addition, for both HB and PHY there was no significant difference between sampling depths.

We applied a Mantel test in pairs to analyze the relationship between the structures of the communities. We observed a significant correlation only between the HB and PHY dissimilarity matrices $(r=0.35, p<0.001)$, indicating these communities co-vary in space and time. 


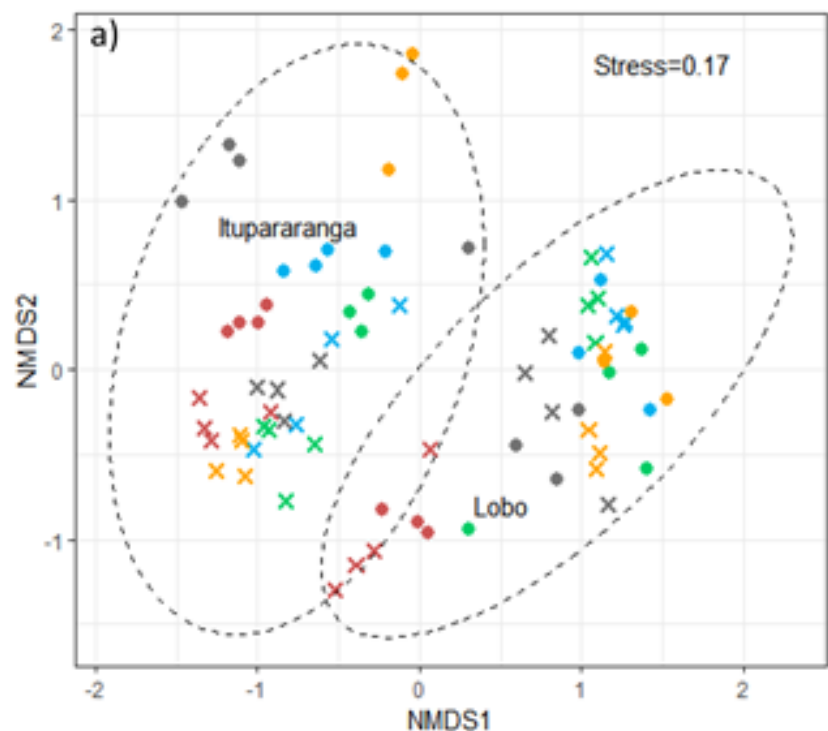

Season

- January

- February

- May

- August

- October

Site

$\times$ Dam

- River_zone

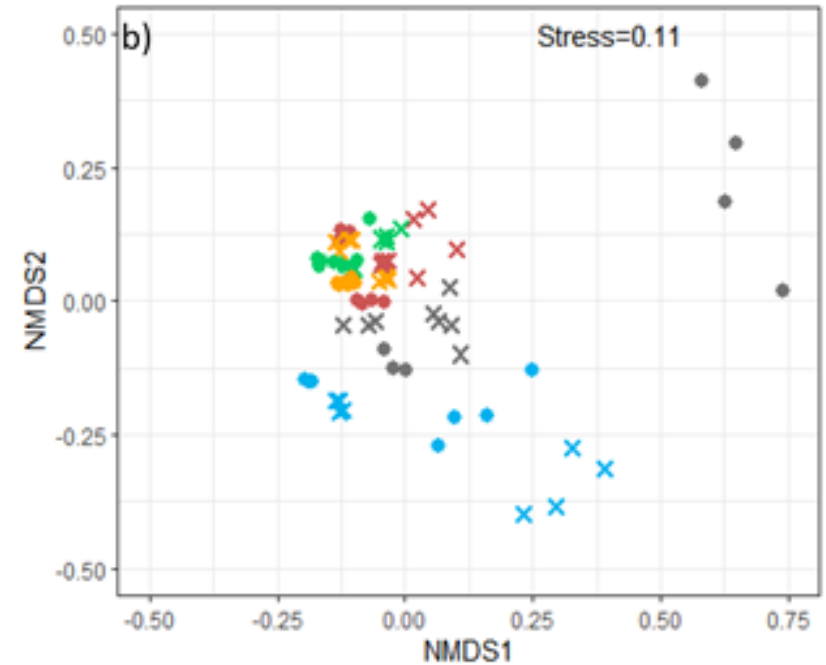

Season

- January

- February

- May

- August

- October

Site

$\times$ Dam

- River_zone

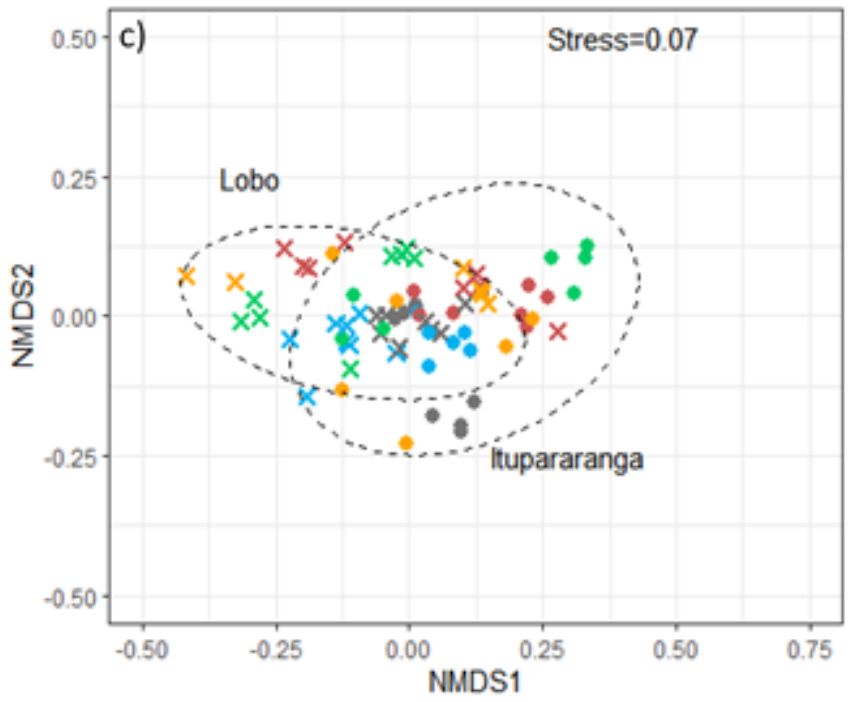

Season

- January

- February

- May

- August

- October

Site

$\times$ Dam

- River_zone

Figure 1-3. Non-metric multidimensional scaling (NMDS) ordination based on Bray Curtis dissimilarity matrix of a) phytoplankton genera/species biomass; b) picophytoplankton cytometric fingerprint; c) heterotrophic bacteria cytometric fingerprint. 
Table 1-3. Permutational multivariate analysis of variance (PERMANOVA) results for the structure of phytoplankton(PHY) and heterotrophic bacteria (HB).

\begin{tabular}{lllll}
\hline & & $\mathrm{F}$ & $\mathrm{R}^{2}$ & $\mathrm{p}$ \\
\hline PHY & Reservoir & 25.3 & 0.22 & $<0.001$ \\
& Site & 7.12 & 0.06 & $<0.001$ \\
& Season & 4.26 & 0.15 & $<0.001$ \\
& Depht & 0.58 & $\mathrm{~ns}$ & $\mathrm{~ns}$ \\
$\mathrm{HB}$ & Reservoir & 26.94 & 0.22 & $<0.001$ \\
& Site & 13.03 & 0.11 & $<0.001$ \\
& Season & 3.34 & 0.11 & $<0.001$ \\
& Depht & 0.58 & $\mathrm{~ns}$ & $\mathrm{~ns}$ \\
\hline
\end{tabular}

ns: non-significant

\section{Influence of environmental factors on communities}

The dbRDA was used to assess the relationships between communities and environmental variables $(\mathrm{pH}$, conductivity, temperature, TSS, transparency, DOC, and DIN). The dbRDA results showed that the environmental variables explained 75.5, 85.1 and $43.5 \%$ in the first two axes of the variation of the PHY, PPP and HB communities, respectively (the three models were significant, ANOVA $\mathrm{p}<0.001$ ). For PHY, the significant variables in the model were $\mathrm{pH}$, conductivity, DOC, DIN, transparency and TSS ( $p<0.0001$ ). The samples from the Itupararanga river zone were grouped and associated with high values of conductivity and TSS, while the samples from its dam were positively related to $\mathrm{pH}$. In the Lobo reservoir, most samples were associated with temperature (Figure 1-4.a). According to the dbRDA, for PPP the significant variables were $\mathrm{pH}, \mathrm{DO}$, conductivity and transparency $(\mathrm{p}<0.001)$. The samples from Itupararanga were related negatively with DO and positively with temperature and transparency.

In the dbRDA applied to $\mathrm{HB}$, the environmental variables $\mathrm{pH}$, temperature, conductivity, DOC, transparency and DIN were significant (p <0.001) (Figure 1-4.c). Most samples from the Itupararanga dam were grouped and associated with water transparency, while samples from the river zone were associated with high temperature and DIN values. In the Lobo reservoir, high concentrations of DOC and conductivity might be important structuring parameters of the bacterial community in the samples from the river zone and the dam, respectively. 

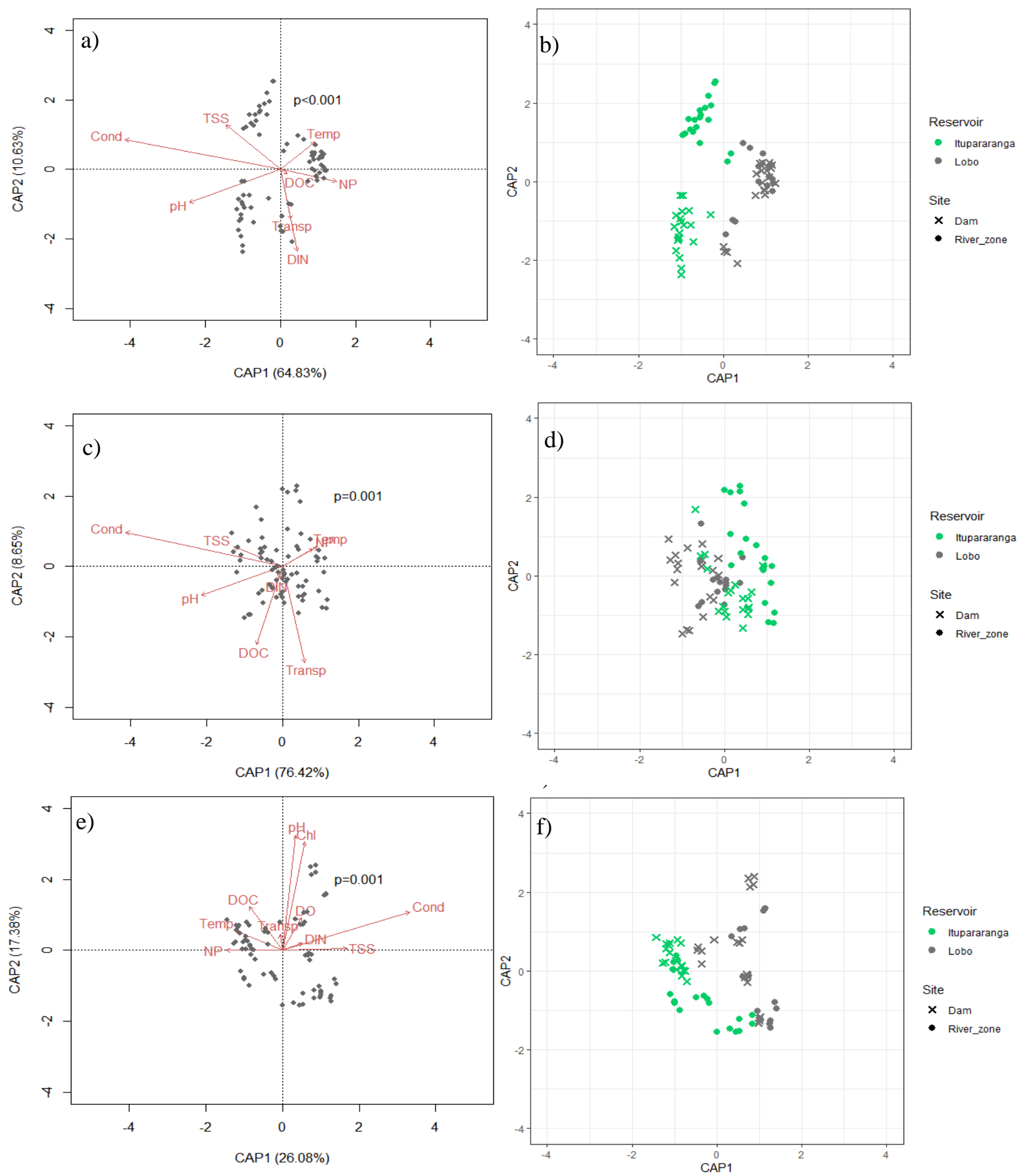

Figure 1-4. Distance-based redundancy analysis (dbRDA) a) phytoplankton biomass composition with environmental factors; b) coordinates of phytoplankton samples; c) picophytoplankton cytometric fingerprint with environmental factors; d) coordinates of picophytoplankton samples; e) heterotrophic bacteria cytometric fingerprint with environmental factors; f) coordinates of heterotrophic bacteria samples. Chl chlorophyll, Cond conductivity, $D I N$ dissolved inorganic nitrogen, $D O$ dissolved oxygen, $D O C$ dissolved organic carbon, $N P$ nitrogen and phosphorus ratio, Temp temperature, Transp transparency, TSS total suspended solids. 


\section{Discussion}

Our study showed differences in the structure of PHY and HB between reservoirs and sites, but the PPP composition seems to be similar. The communities' structures did not vary with depths but were influenced by environmental factors throughout the seasons and the sites.

\section{Communities biomass}

Among the microbial communities analyzed, PHY was the biological component that presented the highest biomass throughout the analyzed period. The amount of carbon associated with the cell volume of many PHY species is much greater than in HB and PPP (Rocha and Duncan 1985; Lee and Fuhrman, 1987; Zubkov et al., 1998). The average PHY biomass in Itupararanga and Lobo were similar to values observed in other subtropical meso-eutrophic reservoirs (Rangel et al., 2012; Domingues et al., 2016). However, HB biomass in our study was higher than in others Brazilian reservoirs (Silva et al 2014). On the other hand, the average HB biomass recorded in an Amazonian tropical floodplain was higher than the results of our research (Feitosa et al., 2019). Floodplain environments are characterized by a complex relationship between rivers and lakes, which associated with the hydrological cycle not only influences biomass but also shapes the composition of the bacterial community (Melo et al., 2018).

In this study, we observed a significative correlation between PHY and HB biomass (Spearman correlation: $r=0.32, p=0.005$ ). Furthermore, the structures of these two communities were also related (Mantel test: $\mathrm{r}=0.35, \mathrm{p}<0.001$ ). In natural environments, HB assimilates dissolved organic carbon from phytoplankton cell lysis, as an exchange, HB remineralizes nutrients to the phytoplankton during the decomposition process (Azam et al. 1983; Gasol et al., 2008). However, the relationship between these communities can be much more complex since many studies suggest that the HB taxonomic composition is strongly influenced by PHY structure, especially during cyanobacterial blooms (Woodhouse et al., 2016; Lu et al., 2018; Xu et al., 2018). Some HB genera are capable of degrading cyanotoxins (Eleuterio and Batista 2010; Zhang et al., 2020), favoring the coexistence of these microorganisms with cyanobacteria (Guedes et al., 2018). Nonetheless, further research is still needed to better understand the metabolic functions that one community has over the other.

The PPP biomass in the Lobo and Itupararanga reservoirs, classified as mesotrophic, was higher than the biomass observed in temperate oligotrophic 
environments (Burns and Calbraith, 2007; Carrick et al., 2017). Previous meta-analysis indicated that the biomass of PHY, composed of Pcy, is higher in tropical lakes (Sarmento, 2012). This is particularly important in oligotrophic lakes because the PPP provides source and carbon to higher trophic levels through food webs (Tarbe et al., 2011). However, this scenario changes in tropical eutrophic ecosystems. In our study, it has been noted that PPP biomass was much lower than PHY biomass. Although PPP biomass increases with increasing trophic level in freshwater environments, the percent contribution of PPP to the total phytoplankton biomass decreased with increasing lake trophic state (Bell and Kalff, 2001).

In addition, there is evidence that in more enriched environments Peuk prevails over Pcy but in oligo-mesotrophic freshwater systems, the opposite usually occurs (Schiaffino et al., 2013). Here, Pcy predominated or co-dominated with Peuk in most of the analyzed periods, possibly due to the intermediate enrichment level of Itupararanga and Lobo reservoirs. It was also observed that Pcy biomass was composed mainly of PCrich Pcy, while the PE-rich cells biomass was very low. Previous studies have reported that PC-rich Pcy prevails in more eutrophic environments (Wang et al., 2009; Schiaffino et al 2013). In these lakes the transparency water is low and there is prevalence of red wavelength light in the euphotic zone, which favors the growth of PC-rich Pcy (Vörös et al., 1998; Camacho et al., 2003). On the other hand, PE-rich Pcy develop better in oligotrophic lakes $\left(\mathrm{Chl}<10 \mu \mathrm{g} . \mathrm{L}^{-1}\right)$ due to the dominance of green wavelength in the water column (Callieri et al 1996; Vörös et al., 1998).

\section{Spatiotemporal patterns in community structure}

Our results suggest that the structures of the PHY and HB communities were shaped by horizontal temporal and spatial heterogeneity, but not by depth. The phytoplankton homogeneity in the water column has also been reported in previous studies (Calasi et al., 2017; Cunha et al., 2017).However, Denaturing Gradient Gel Electrophoresis (DGGE) analyses suggested that the bacterial composition varies from surface to bottom, probably due to the thermal stratification of the water column and also due to the proximity of the collection point to the sediment (Soares et al., 2015). In our study, the water column tended to be well mixed throughout the sampling period (with few exceptions, Figure S1-2), which probably contributed to the homogenization of the communities, as observed here. 
The PERMANOVA analysis has demonstrated that the structure of PHY and HB was different between reservoirs. The NMDS shows this clear division between the samples from Itupararanga and Lobo, suggesting that the taxonomic composition of PHY (Figure 1-3.a) and HB (Figure 1-3.c) are different between the reservoirs. There is evidence that the cytometric fingerprint is related to the taxonomy of communities (Vila Costa et al., 2012; Garcia et al., 2015), however there are no records about HB taxonomic composition in the Lobo and Itupararanga reservoirs. Previous studies have reported a consistent pattern of PHY composition in Itupararanga, with a predominance of cyanobacteria, specifically Raphidiopsis raciborskii (previously Cylindrospermopsis raciborskii) and chlorophytes (Beghelli et al 2016; Calasi et al., 2017; Cunha et al., 2017), while in Lobo there is a predominance of diatoms, such as Aulocoseira sp., chlorophytes and cyanobacteria (Tundisi et al., 2015; Vicentin et al., 2018).

Regarding the PPP structure, we were unable to detect temporal and spatial patterns through PERMANOVA, since the beta dispersion was significant. However, the NMDS shows a great overlap of points between Itupararanga and Lobo, suggesting a similarity between communities in the reservoirs. This result is aligned with the biomass values found in this study, in which PC-rich Pcy was the main contributor to PPP in both reservoirs.

For HB and PHY, an evident separation between sampling sites was also observed. At the upstream of the reservoirs, the rivers that enter in this region are responsible for influencing the physicochemical characteristics of the water and consequently impact the microbial communities (Thornton, 1990). This region, also called the river zone, generally has low depth, high concentration of total suspended solids, low light incidence and high concentrations of nutrients (Thornton, 1990) due to the highest influence of terrestrial surroundings, and enhanced contribution of allochthonous materials. In this study, it has been found that PHY, PPP and HB were influenced by these environmental variables. The low transparency of the water is a consequence of the high TSS concentrations and limits phytoplankton growth (Cunha and Calijuri, 2011).

Nonetheless, the high transparency observed in the dam of both reservoirs, positively influenced PHY in Lobo, and PPP and HB in Itupararanga. The association between HB and water transparency has also found in the Funil reservoir (Guedes et al., 2018). The period presenting low retention time and less water turbidity coincided with the blooming of Raphidiopsis raciborskii and the elevation on the relative abundance of 
the phylum Planctomycetes but, when there were low water transparency and high retention time, there were blooms of Microcystis and high abundance of Bacteroidetes (Guedes et al., 2018).

Previous studies have reported that DOC is another important factor for the structure of HB and PHY (Reis et al., 2019). It was observed in this study that DOC concentrations in Itupararanga and Lobo varied over time (Table 1-1) and was characteristic of mesotrophic environments. Song et al (2018) showed that the average concentrations of DOC in oligotrophic, mesotrophic and eutrophic reservoirs were 2.6, 5.2 , and $14.7 \mathrm{mg} \mathrm{L}^{-1}$, respectively. These results suggest that the amount of DOC in the environment is influenced by eutrophication, which can affect HB and PHY structures.

The input of nutrients from anthropic origin into the reservoirs is well known for its effects on microbial communities, especially increasing phytoplankton biomass (Yang et al., 2017; Glibert, 2017; Lurling et al., 2018; Gámez, Benton and Manning, 2019). It has also been reported that $\mathrm{NO}_{3}{ }^{-}$has a strong influence on the $\mathrm{HB}$ structures in rivers impacted by urbanization (Wang et al., 2018;). Here, DIN was composed mainly of $\mathrm{NO}_{3}{ }^{-}$ and also significantly influenced the HB structure, thus may be was the main responsible for separation of the samples between the dam and river zone.

Conductivity and $\mathrm{pH}$ also affect the structure of the PHY community (Silva et al., 2014), PPP (Callieri et al 2012; Li et al., 2016), bacterial cytometric diversity (Quiroga et al., 2017) and the taxonomic composition of bacteria (Ávila et al., 2017). The high conductivity observed in Itupararanga is typical of eutrophic environments, where a positive correlation between conductivity and cyanobacteria has already been detected (Silva et al., 2014). In addition, $\mathrm{pH}$ is essential for microbial metabolism and small variations in its values may be responsible for changing the bacterial community composition (Krause et al., 2012; Llirós et al., 2014).

Zooplanktonic predation (not evaluated in this study) can also affect the biomass and the diversity of microbial communities. Copepods, cladocerans and rotifers are able to feed on phytoplankton, including toxic cyanobacteria (Soares, Lürling, Huszar, 2010; Hong et al., 2013; Agasild et al., 2019), picocyanobacteria (Rocha et al., 2019) and heterotrophic bacteria (Segovia et al 2018). We suggest further studies about the influence of zooplankton on the microbial community in the Lobo and Itupararanga reservoirs. 


\section{Conclusion}

In conclusion, PHY was the component that had the highest biomass values among the communities analyzed. The structure and biomass between HB and PHY were related, however we recommend future studies to analyze the taxonomic associations between these groups. Our results suggest that water transparency, $\mathrm{pH}$ and conductivity were key environmental variables that significantly shaped the structure of PHY, PPP and HB communities. However, DOC and DIN concentrations were also important for PHY and HB. Microorganisms are sensitive to changes in water composition, especially to the eutrophication process, so they can be good indicators of anthropic changes. The use of flow cytometry and the cytometric fingerprint techniques have allowed us to identify spatial and temporal patterns in the structure of HB and PPP communities, and stand out as cost-efficiency approaches for future studies. These tools can help researchers to handle large amounts of samples from different environments, thus targeting important questions in Microbial Ecology, and expanding knowledge about the functioning of aquatic ecosystems.

\section{Acknowledgements}

This study was funded by Fundação de Amparo à Pesquisa do Estado de São Paulo (FAPESP - process number 2016/09405-1). R.A.M.R is grateful for the doctoral scholarships provide by Coordenação de Aperfeiçoamento de Pessoal de Nível Superior - Brasil (CAPES) - Finance Code 001 and Conselho Nacional de Desenvolvimento e Pesquisa Tecnológica (CNPq - process number 142176/2016-8). M.A.B.M is thankful to FAPESP (process numbers 2015/21191-4 and 2018/00394-2) for providing doctoral scholarships. 


\section{References}

American Public Health Association - APHA. (2005). Standard methods: for the examination of water and wastewater, $21^{\text {st }}$ ed. APHA, Washington.

Agasild, H., Panksep, K., Tõnno, I., Blank, K., Kõiv, T., Freiberg, R., Laugast, R., Jones, R.I, Nogões, P., Nõges, T. (2019). Role of potentially toxic cyanobacteria in crustacean zooplankton diet in a eutrophic lake. Harmful algae, 89, 1-14.

Alves-de-Souza, C., Benevides, T. S., Santos, J. B., Von Dassow, P., Guillou, L., Menezes, M. (2017). Does environmental heterogeneity explain temporal $\beta$ diversity of small eukaryotic phytoplankton? Example from a tropical eutrophic coastal lagoon. Journal of Plankton Research, 39(4), 698-714.

Ávila, M. P., Staehr, P. A., Barbosa, F. A., Chartone-Souza, E., Nascimento, A. (2017). Seasonality of freshwater bacterioplankton diversity in two tropical shallow lakes from the Brazilian Atlantic Forest. FEMS microbiology ecology, 93(1), 1-11.

Azam, F., T. Fenchel, J. G. Field, J. S. Gray, L. A. Meyer-Reil, and F. Thingstad. (1983). The ecological role of water-column microbes in the sea. Mar. Ecol: Prog. Ser. 10, 257-263.

Beghelli, F. G., Frascareli, D., Pompêo, M. L. M., Moschini-Carlos, V. (2016). Trophic State Evolution over 15 Years in a Tropical Reservoir with Low Nitrogen Concentrations and Cyanobacteria Predominance. Water, Air, and Soil Pollution, 227(3), 1-15.

Bell, T., Kalff, J. (2001). The contribution of picophytoplankton in marine and freshwater systems of different trophic status and depth. Limnology and Oceanography, 46(5), 1243-1248.

Biddanda, B., Ogdahl, M., Cotner, J. (2001). Dominance of bacterial metabolism in oligotrophic relative to eutrophic waters. Limnology and oceanography, 46(3), 730-739.

Bortolini, J. C., da Silva, P. R. L., Baumgartner, G., Bueno, N. C. (2019). Response to environmental, spatial, and temporal mechanisms of the phytoplankton metacommunity: comparing ecological approaches in subtropical reservoirs. Hydrobiologia, 830(1), 45-61.

Burns, C. W., Galbraith, L. M. (2007). Relating planktonic microbial food web structure in lentic freshwater ecosystems to water quality and land use. Journal of plankton research, 29(2), 127139.

Callieri, C., Amicucci, E., Bertoni, R., Vörös, L. (1996) Fluorometric characterization of two picocyanobacteria strains from lakes of different underwater light quality. Internationale Revue der gesamten Hydrobiologie und Hydrographie, 81(1), 13-23.

Callieri, C., Caravati, E., Corno, G., Bertoni, R. (2012). Picocyanobacterial community structure and space-time dynamics in the subalpine Lake Maggiore (N. Italy). Journal of Limnology, 71(1), e9.

Camacho, A., Miracle, M. R., Vicente, E. (2003). Which factors determine the abundance and distribution of picocyanobacteria in inland waters? A comparison among different types of lakes and ponds. Archiv für Hydrobiologie, 157(3), 321-338.

Carrick, H., Cafferty, E., Ilacqua, A., Pothoven, S., Fahnenstiel, G. (2017). Seasonal abundance, biomass and morphological diversity of picoplankton in lake superior: importance of water column mixing. International Journal of Hydrology, 1, 1-14. 
Casali, S. P., Dos Santos, A. C. A., de Falco, P. B., Calijuri, M. C. (2017). Influence of environmental variables on saxitoxin yields by Cylindrospermopsis raciborskii in a mesotrophic subtropical reservoir. Journal of water and health, 15(4), 509-518.

Cunha, D. G. F., Calijuri, M. C. (2011). Limiting factors for phytoplankton growth in subtropical reservoirs: the effect of light and nutrient availability in different longitudinal compartments. Lake and Reservoir Management, 27(2), 162-172.

Cunha, D. G. F., Calijuri, M. C., Lamparelli, M.C. (2013). A trophic state index for tropical/subtropical reservoirs (TSI tsr). Ecological Engineering, 60, 126-134.

Cunha, D.G.F., Lima, V.F.M., Néri, A.M., Marafão, G.A., Miwa, A.C.P., Calijuri., M.C., Bendassoli, J.A., Tromboni, F. et al. (2017). Uptake rates of ammonium and nitrate by phytoplankton communities in two eutrophic tropical reservoirs. International Review of Hydrobiology, 102(5-6), 125-134.

Cupertino, A., Gücker, B., Von Rückert, G., Figueredo, C. C. (2019). Phytoplankton assemblage composition as an environmental indicator in routine lentic monitoring: Taxonomic versus functional groups. Ecological indicators, 101, 522-532.

Domingues, C. D., da Silva, L. H. S., Rangel, L. M., de Magalhães, L., de Melo Rocha, A., Lobão, L. M.,Paiva, R., Roland, F., Sarmento, H. (2016). Microbial food-web drivers in tropical reservoirs. Microbial ecology, 73(3), 505-520.

Eleuterio, L., Batista, J. R. (2010). Biodegradation studies and sequencing of microcystin-LR degrading bacteria isolated from a drinking water biofilter and a freshwater lake. Toxicon, 55(8), 1434-1442.

Feitosa, I. B., Huszar, V. L. M., Domingues, C. D., Appel, E., Paranhos, R., Almeida, R. M., Branco, C.W.C., Bastos, W. R., Sarmento, H. (2019). Plankton community interactions in an Amazonian floodplain lake, from bacteria to zooplankton. Hydrobiologia, 831(1), 55-70.

Frascareli, D., Cardoso-Silva, S., Mizael, J. D. O. S. S., Rosa, A. H., Pompêo, M. L. M., LópezDoval, J. C., Moschini-Carlos, V. (2018). Spatial distribution, bioavailability, and toxicity of metals in surface sediments of tropical reservoirs, Brazil. Environmental Monitoring and Assessment, 190(4), 1-15.

Gámez, T. E., Benton, L., Manning, S. R. (2019). Observations of two reservoirs during a drought in central Texas, USA: Strategies for detecting harmful algal blooms. Ecological Indicators, 104, 588-593.

García, F. C., Alonso-Sáez, L., Morán, X. A. G., López-Urrutia, Á. (2015). Seasonality in molecular and cytometric diversity of marine bacterioplankton: the re-shuffling of bacterial taxa by vertical mixing. Environmental microbiology, 17(10), 4133-4142.

Gasol, J.M., Pinhassi, J., Alonso-Sáez, L., Ducklow, H., Herndl, G.J., Koblizek, M., Labrenz, M., Luo, Y. et al. (2008). Towards a better understanding of microbial carbon flux in the sea. Aquat Microb Ecol, 53(1), 21-38.

Glibert, P. M. (2017). Eutrophication, harmful algae and biodiversity-Challenging paradigms in a world of complex nutrient changes. Marine pollution bulletin, 124(2), 591-606. 
Guedes, I. A., Rachid, C. T., Rangel, L. M., Silva, L. H., Bisch, P. M., Azevedo, S. M., Pacheco, A. B. (2018). Close link between harmful cyanobacterial dominance and associated bacterioplankton in a tropical eutrophic reservoir. Frontiers in microbiology, 9, 1-13.

Hillebrand, H., Dürselen, C. D., Kirschtel, D., Pollingher, U., Zohary, T. (1999). Biovolume calculation for pelagic and benthic microalgae. Journal of phycology, 35(2), 403-424.

Hong, Y., Burford, M. A., Ralph, P. J., Udy, J. W., Doblin, M. A. (2013). The cyanobacterium Cylindrospermopsis raciborskii is facilitated by copepod selective grazing. Harmful algae, 29, 14-21.

Kleinteich, J., Hilt, S., Hoppe, A., Zarfl, C. (2020). Structural changes of the microplankton community following a pulse of inorganic nitrogen in a eutrophic river. Limnology and Oceanography, 65, S264-S276.

Koroleff, F. (1976). Determination of nutrients: Ammonia. In Methods of seawater analysis. Verlag Chemie, Weinheim: 126-133.

Krause, E., Wichels, A., Giménez, L., Lunau, M., Schilhabel, M. B., Gerdts, G. (2012). Small changes in $\mathrm{pH}$ have direct effects on marine bacterial community composition: a microcosm approach. PloS one, 7, e47035.

Kumar, P., Hegde, K., Brar, S. K., Cledon, M., Kermanshahi pour, A. (2018). Physico-chemical treatment for the degradation of cyanotoxins with emphasis on drinking water treatment-How far have we come?. Journal of environmental chemical engineering, 6(4), 5369-5388.

Legendre, P.; L. Legendre, 1998. Numerical Ecology. Elsevier Science, Amsterdam.

Lewis Jr, W. M. (1987). Tropical limnology. Annual review of ecology and systematics, 18(1), $159-184$

Llirós, M., Inceoğlu, Ö., García-Armisen, T., Anzil, A., Leporcq, B., Pigneur, L. M., Viroux, L., Darchambeau, F. et al. (2014). Bacterial community composition in three freshwater reservoirs of different alkalinity and trophic status. PLoS One, 9(12), e116145.

Li, W. K. W. (1997). Cytometric diversity in marine ultraphytoplankton. Limnology and Oceanography, 42(5), 874-880.

Li, S., Shi, X., Lepère, C., Liu, M., Wang, X., Kong, F. (2016). Unexpected predominance of photosynthetic picoeukaryotes in shallow eutrophic lakes. Journal of Plankton Research, 38(4), 830-842.

Loftin, K. A., Graham, J. L., Hilborn, E. D., Lehmann, S. C., Meyer, M. T., Dietze, J. E., Griffith, C. B. (2016). Cyanotoxins in inland lakes of the United States: Occurrence and potential recreational health risks in the EPA National Lakes Assessment 2007. Harmful Algae, 56, 77-90.

Lu, L., Xu, L., Yang, J., Li, Z., Guo, J., Xiao, Y., Yao, J. (2018). Contribution of heterotrophic bacterioplankton to cyanobacterial bloom formation in a tributary backwater area of the Three Gorges Reservoir, China. Environmental Science and Pollution Research, 25(27), 27402-27412.

Lurling, M., Mello, M. M., van Oosterhout, F., De Senerpont Domis, L. N., Marinho, M. M. (2018). Response of natural cyanobacteria and algae assemblages to a nutrient pulse and elevated temperature. Frontiers in microbiology, 9, 1-14. 
Lee S., Fuhrman J. A. (1987). Relationships between biovolume and biomass of naturally derived marine bacterioplankton. Applied and Environmental Microbiology, 53(6), 1298-1303.

Liu, J., Chen, Y., Li, M., Liu, B., Liu, X., Wu, Z., Cai, W., Xu, J., Wang, J. (2019). Water-level fluctuations are key for phytoplankton taxonomic communities and functional groups in Poyang Lake. Ecological Indicators, 104, 470-478.

Magalhães, A. A. D. J., Luz, L. D., Aguiar Junior, T. R. (2019). Environmental factors driving the dominance of the harmful bloom-forming cyanobacteria Microcystis and Aphanocapsa in a tropical water supply reservoir. Water Environment Research, 91(11), 1466-1478.

Merel, S., Walker, D., Chicana, R., Snyder, S., Baurès, E., Thomas, O. (2013). State of knowledge and concerns on cyanobacterial blooms and cyanotoxins. Environment international, 59, 303327.

Melo, M. L., Bertilsson, S., Amaral, J. H. F., Barbosa, P. M., Forsberg, B. R., Sarmento, H. (2018). Flood pulse regulation of bacterioplankton community composition in an Amazonian floodplain lake. Freshwater biology, 64(1), 108-120.

Nusch, E. A. (1980). Comparison of different methods for chlorophyll and pheopigment determination. Archiv für Hydrobiologie, 14, 14-36.

Oksanen, J., Blanchet, F. G., Kindt, R., Legendre, P., Minchin, P., O’Hara, R. B., ... Wagner, H. (2015). Vegan: Community ecology package. R package vegan, version. 2.2-1.

Periotto, N. A.; Tundisi, J. G. (2013). Ecosystem Services of UHE Carlos Botelho (Lobo/Broa): a new approach for management and planning of dams multiple-uses. Brazilian Journal of Biology, 73(3), 471-482.

Pomeroy, L. (1974). The Ocean's Food Web, A Changing Paradigm. BioScience,, 24(9), 499-504.

Quiroga, M. V., Mataloni, G., Wanderley, B. M., Amado, A. M., Unrein, F. (2017). Bacterioplankton morphotypes structure and cytometric fingerprint rely on environmental conditions in a sub-Antarctic peatland. Hydrobiologia, 787(1), 255-268.

R Development Core Team. (2008). R: A language and environment for statistical computing. R Foundation for Statistical Computing, Vienna, Austria. ISBN 3-900051-07-0, URL http://www.R-project.org

Rangel, L. M., Silva, L. H., Rosa, P., Roland, F., Huszar, V. L. (2012). Phytoplankton biomass is mainly controlled by hydrology and phosphorus concentrations in tropical hydroelectric reservoirs. Hydrobiologia, 693(1), 13-28.

Reis, M. C., Bagatini, I. L., de Oliveira Vidal, L., Bonnet, M. P., da Motta Marques, D., Sarmento, H. (2019). Spatial heterogeneity and hydrological fluctuations drive bacterioplankton community composition in an Amazon floodplain system. PloS one, 14(8), e0220695.

Rocha, O., Duncan, A. (1985). The relationship between cell carbon and cell volume in freshwater algal species used in zooplanktonic studies. Journal of Plankton Research, 7(2), 279-294.

Rocha, M. I. A., Recknagel, F., Minoti, R. T., Huszar, V. L. M., Kozlowsky-Suzuki, B., Cao, H., Starling, F. L. R. M., Branco, C. W. C. (2019). Assessing the effect of abiotic variables and zooplankton on picocyanobacterial dominance in two tropical mesotrophic reservoirs by means of evolutionary computation. Water research, 149, 120-129. 
Santana, L. M., Weithoff, G., Ferragut, C. (2017). Seasonal and spatial functional shifts in phytoplankton communities of five tropical reservoirs. Aquatic ecology, 51(4), 531-543.

Sarmento, H., Unrein, F., Isumbisho, M., Stenuite, S., Gasol, J. M., Descy, J. P. (2008). Abundance and distribution of picoplankton in tropical, oligotrophic Lake Kivu, eastern Africa. Freshwater Biology, 53(4), 756-771

Sarmento, H. (2012). New paradigms in tropical limnology: the importance of the microbial food web. Hydrobiologia, 686(1), 1-14.

Schiaffino, M. R., Gasol, J. M., Izaguirre, I., Unrein, F. (2013). Picoplankton abundance and cytometric group diversity along a trophic and latitudinal lake gradient. Aquatic Microbial Ecology, 68(3), 231-250.

Segovia, B. T., Meira, B. R., Lansac-Toha, F. M., Amadeo, F. E., Unrein, F., Velho, L. F. M., Sarmento, H. (2018). Growth and cytometric diversity of bacterial assemblages under different top-down control regimes by using a size-fractionation approach. Journal of Plankton Research, 40(2), 129-141.

Sieburth, J. M., Smetacek, V., Lenz, J. (1978). Pelagic ecosystem structure: Heterotrophic compartments of the plankton and their relationship to plankton size fractions. Limnology and oceanography, 23(6), 1256-1263.

Silva, L. H., Huszar, V. L., Marinho, M. M., Rangel, L. M., Brasil, J., Domingues, C. D., Branco, C.C., Roland, F. (2014). Drivers of phytoplankton, bacterioplankton, and zooplankton carbon biomass in tropical hydroelectric reservoirs. Limnologica-Ecology and Management of Inland Waters, 48, 1-10.

Soares, M. C. S., Lürling, M., Huszar, V. L. (2010). Responses of the rotifer Brachionus calyciflorus to two tropical toxic cyanobacteria (Cylindrospermopsis raciborskii and Microcystis aeruginosa) in pure and mixed diets with green algae. Journal of Plankton Research, 32(7), 9991008 .

Soares, L. A., Santos, A. C. A. D., Duarte, I. C. S., Romagnoli, E. M., Calijuri, M. D. C. (2015). Distribution of Archaeal and Bacterial communities in a subtropical reservoir. Acta Limnologica Brasiliensia, 27(4), 411-420.

Song, K., Wen, Z., Shang, Y., Yang, H., Lyu, L., Liu, G., Fang, C., Du, J., Zhao, Y. (2018). Quantification of dissolved organic carbon (DOC) storage in lakes and reservoirs of mainland China. Journal of environmental management, 217, 391-402.

Sotero-Santos, R. B., Silva, C. R. D. S. E., Verani, N. F., Nonaka, K. O., Rocha, O. (2006). Toxicity of a cyanobacteria bloom in barra bonita reservoir (middle tiete river, Sao Paulo, Brazil). Ecotoxicology and Environmental Safety, 64(2), 163-170.

Stenuite, S., Tarbe, A. L., Sarmento, H., Unrein, F., Pirlot, S., Sinyinza, D., Thill, S., Lecomte, M. et al. (2009). Photosynthetic picoplankton in Lake Tanganyika: biomass distribution patterns with depth, season and basin. Journal of Plankton Research, 31(12), 1531-1544.

Su, X., Steinman, A. D., Xue, Q., Zhao, Y., Tang, X., Xie, L. (2017). Temporal patterns of phytoand bacterioplankton and their relationships with environmental factors in Lake Taihu, China. Chemosphere, 184, 299-308.

Sun, J., Liu, D. (2003). Geometric models for calculating cell biovolume and surface area for phytoplankton. Journal of plankton research, 25(11), 1331-1346. 
Tarbe, A. L., Unrein, F., Stenuite, S., Pirlot, S., Sarmento, H., Sinyinza, D., \& Descy, J. P. (2011). Protist herbivory: a key pathway in the pelagic food web of Lake Tanganyika. Microbial ecology, 62(2), 314-323.

Te, S. H., Gin, K. Y. H. (2011). The dynamics of cyanobacteria and microcystin production in a tropical reservoir of Singapore. Harmful Algae, 10(3), 319-329.

Thornton, K. M., Kimmel, L. B., Fonest, E. P. (1990). Reservoir limnology: ecological perspectives. John Wile, New York.

Tundisi, J. G., Matsumura-Tundisi, T., Tundisi, J. E. M., Blanco, F. P., Abe, D. S., Campanelli, L. C., ... Lima, C. P. P. (2015). A bloom of cyanobacteria (Cylindrospermopsis raciborskii) in UHE Carlos Botelho (Lobo/Broa) reservoir: a consequence of global change? Brazilian Journal of Biology, 75(2), 507.

Utermöhl, H. (1958). Zur vervollkommnung der quantitativen phytoplankton - methodik. Verhandlungen der Internationalen Vereinigung für Theoretische und Angewandte Limnologie, 9, 1-38.

Vicentin, A. M., Rodrigues, E. H. C., Moschini-Carlos, V., Pompêo, M. L. M. (2018). Is it possible to evaluate the ecological status of a reservoir using the phytoplankton community?. Acta Limnologica Brasiliensia, 30, e306.

Vörös, L., Callieri, C., Katalin, V., Bertoni, R. (1998). Freshwater picocyanobacteria along a trophic gradient and light quality range. In Phytoplankton and Trophic Gradients. Springer, Dordrecht: 117-125.

Vila-Costa, M., Gasol, J. M., Sharma, S., Moran, M. A. (2012). Community analysis of high-and low-nucleic acid-containing bacteria in NW Mediterranean coastal waters using 16S rDNA pyrosequencing. Environmental Microbiology, 14(6), 1390-1402.

Wanderley, B. M. S., M. V. Quiroga, A. M. Amado., F. Unrein, (2015). flowDiv: Cytometric Diversity Indices from FlowJo Workspaces. R package version 1.0.

Wanderley, B.M.S., A. Araújo, D.S., Quiroga, M.V., Amado, A.M., Neto, A.D.D., Sarmento, H., Metz, S.D., Unren, F. (2019). flowDiv: a new pipeline for analyzing flow cytometric diversity. BMC Bioinformatics, 20(1), 1-10.

Wang, B., Liu, F., Wang, C.Q., Yu, Y. and Wu, Y. (2009). Flow cytometric observation of picophytoplankton community structure in the cascade reservoirs along the Wujiang River, SW China. J. Limnol., 68, 53-63

Wang, L., Zhang, J., Li, H., Yang, H., Peng, C., Peng, Z., Lu, L. (2018). Shift in the microbial community composition of surface water and sediment along an urban river. Science of the Total Environment, 627, 600-612.

Wickham, H. (2009). ggplot2: Elegant graphics for data analysis. New York, NY: Springer-Verlag.

Woodhouse, J. N., Kinsela, A. S., Collins, R. N., Bowling, L. C., Honeyman, G. L., Holliday, J. K., Neilan, B. A. (2016). Microbial communities reflect temporal changes in cyanobacterial composition in a shallow ephemeral freshwater lake. The ISME journal, 10(6), 1337-1351. 
Worden, A. Z., Nolan, J. K., Palenik, B. (2004). Assessing the dynamics and ecology of marine picophytoplankton: the importance of the eukaryotic component. Limnology and oceanography, 49(1), 168-179.

Xu, Z., Woodhouse, J. N., Te, S. H., Gin, K. Y. H., He, Y., Xu, C., Chen, L. (2018). Seasonal variation in the bacterial community composition of a large estuarine reservoir and response to cyanobacterial proliferation. Chemosphere, 202, 576-585.

Yang, J. R., Lv, H., Isabwe, A., Liu, L., Yu, X., Chen, H., Yang, J. (2017). Disturbance-induced phytoplankton regime shifts and recovery of cyanobacteria dominance in two subtropical reservoirs. Water research, 120, 52-63.

Yang, Y., Gu, X., Te, S. H., Goh, S. G., Mani, K., He, Y., Gin, K. Y. H. (2019). Occurrence and distribution of viruses and picoplankton in tropical freshwater bodies determined by flow cytometry. Water research, 149, 342-350.

Zhang, W., Zhou, Y., Jeppesen, E., Wang, L., Tan, H., Zhang, J. (2019). Linking heterotrophic bacterioplankton community composition to the optical dynamics of dissolved organic matter in a large eutrophic Chinese lake. Science of the Total Environment, 679, 136-147.

Zhang, X., Yang, F., Chen, L., Feng, H., Yin, S., Chen, M. (2020). Insights into ecological roles and potential evolution of Mlr-dependent microcystin-degrading bacteria. Science of The Total Environment, 710, 1-11.

Zubkov, M. V., Sleigh, M. A., Tarran, G. A., Burkill, P. H., Leakey, R. J. (1998). Picoplanktonic community structure on an Atlantic transect from $50 \mathrm{~N}$ to $50 \mathrm{~S}$. Deep Sea Research Part I: Oceanographic Research Papers, 45(8), 1339-1355. 


\section{Supplementary material}

a)
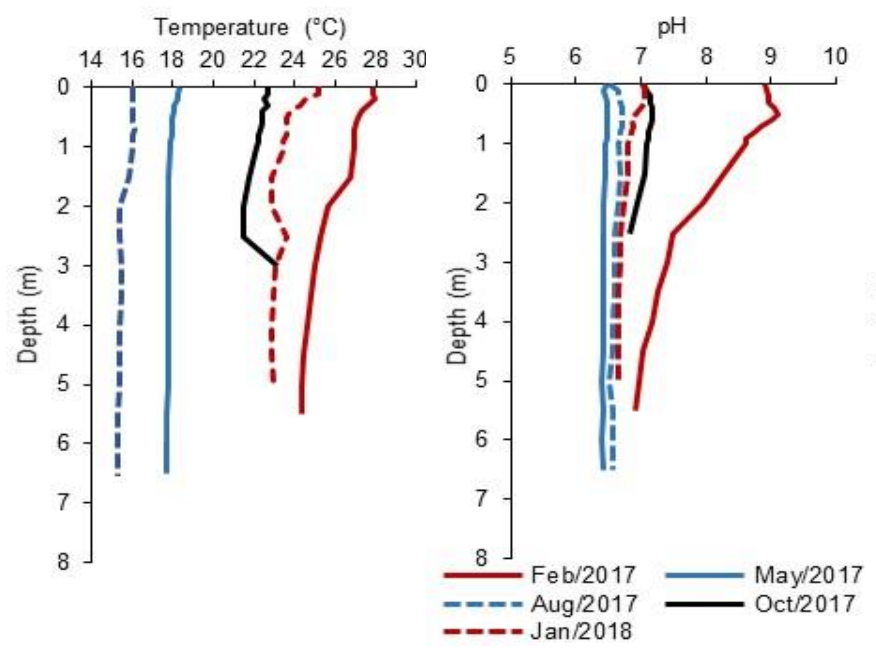

b)
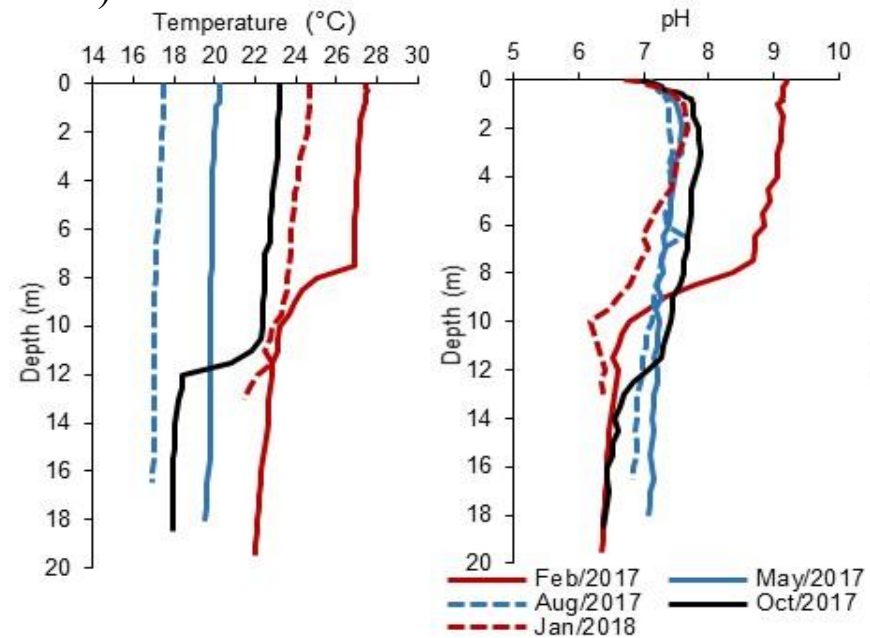

DO (mg. $\left.L^{-1}\right)$

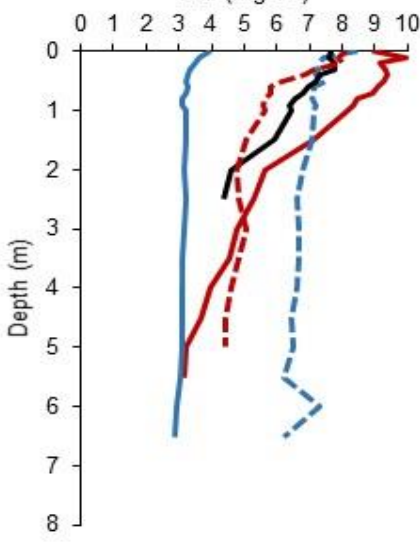

$\mathrm{DO}\left(\mathrm{mg} \cdot \mathrm{L}^{-1}\right)$

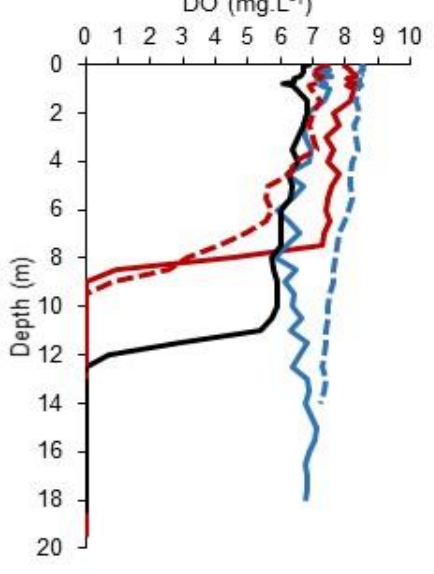

Figure S1-1. Vertical profile of temperature, $\mathrm{pH}$ and dissolved oxygen in Itupararanga reservoir: (a) river zone; (b) dam zone. 
a)
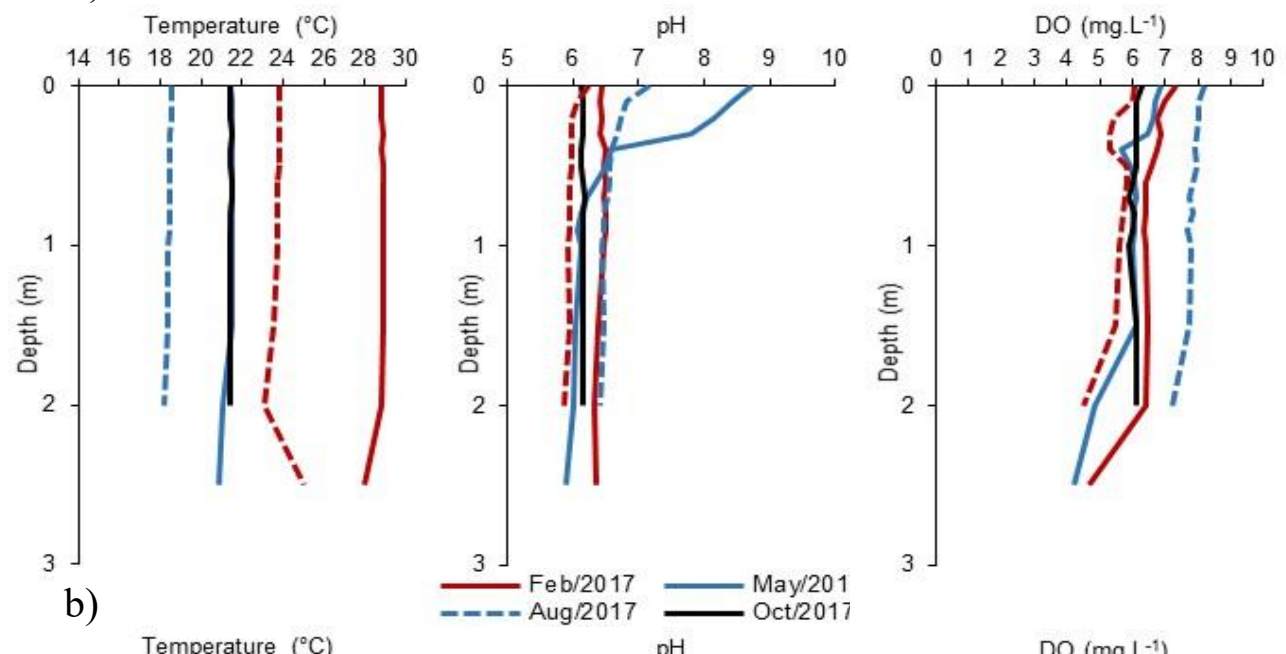

b)

Temperature $\left({ }^{\circ} \mathrm{C}\right)$
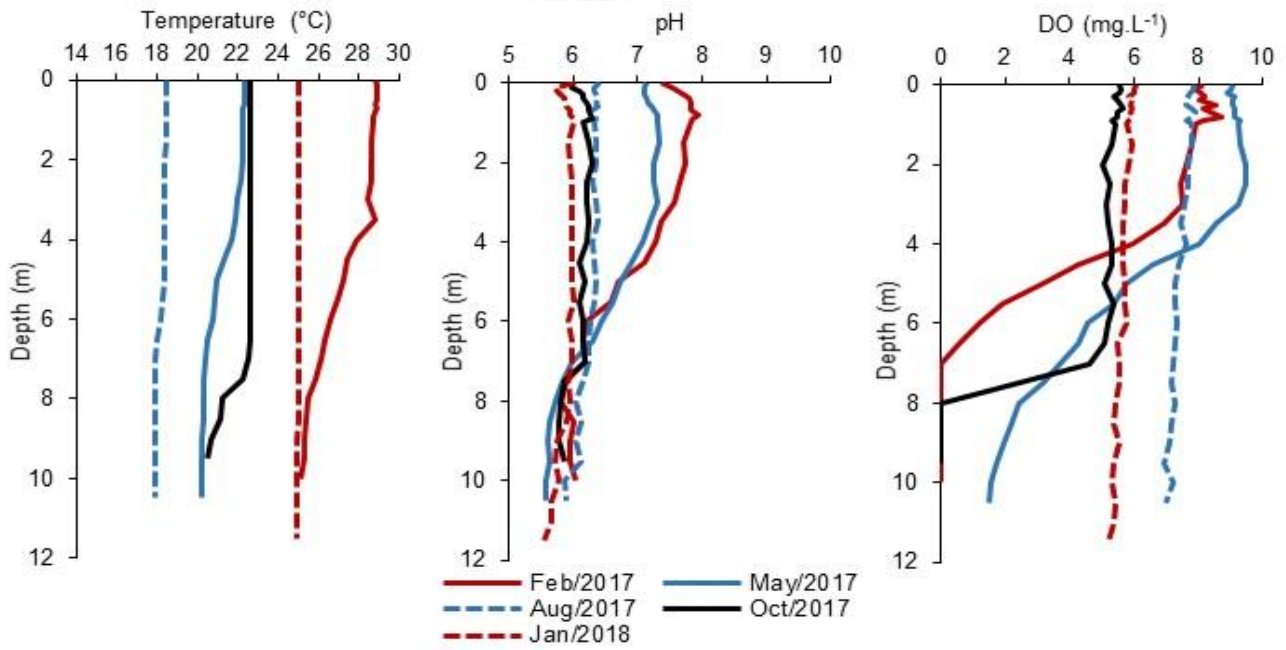

Figure S1-2. Vertical profile of temperature, $\mathrm{pH}$ and dissolved oxygen in the Lobo reservoir: (a) river zone; (b) dam. 

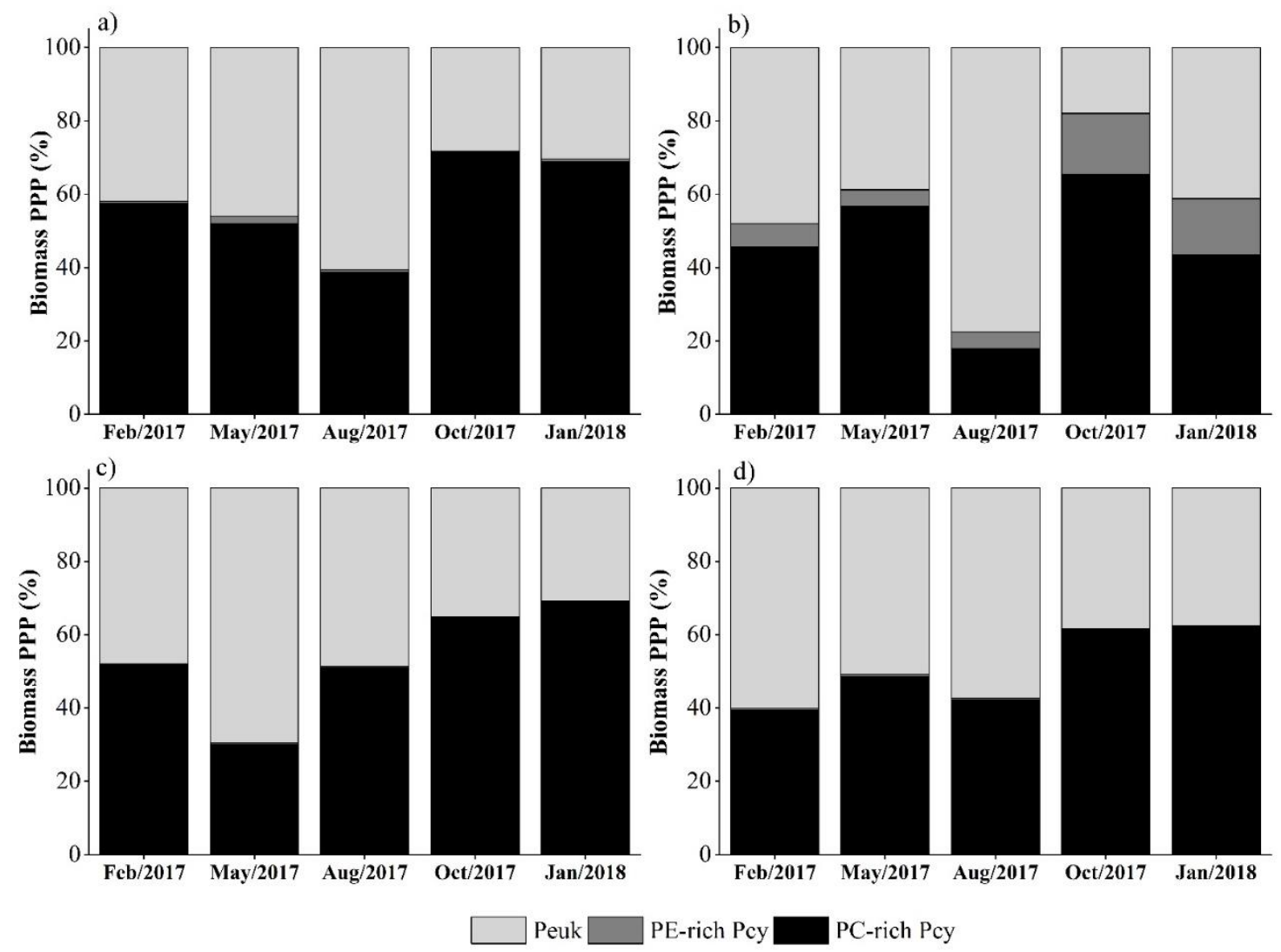

Figure S1-3. Contribution of eukaryotic picophytoplankton (Peuk) and picocyanobacteria rich in phycocyanin (PC-rich Pcy) and phycoerythrin (PE-rich Pcy) to the total biomass of picophytoplankton (PPP). a) Itupararanga river zone; b) Itupararanga dan; c) Lobo river zone; d) Lobo dam. 


\title{
CAPÍTULO 2 - Linking aquatic microbial communities to nitrogen cycling in subtropical reservoirs
}

\begin{abstract}
Nitrogen $(\mathrm{N})$ is essential for the metabolism and growth of phytoplankton and bacterioplankton. The composition in these communities is strongly related to the type of dissolved inorganic nitrogen (DIN) available in the water, generally distributed on the forms of nitrate $\left(\mathrm{NO}_{3}{ }^{-}\right)$and ammonium $\left(\mathrm{NH}_{4}{ }^{+}\right)$. This study aimed to analyze the composition of phytoplanktonic and bacterial communities and at investigating their roles on nitrogen metabolism in subtropical reservoirs. To accomplish this, we collected water samples from Brazilian reservoirs Itupararanga-SP and Lobo-SP at two distinct sites, dam zone and river zone. Experiments in situ with ${ }^{15} \mathrm{~N}$ isotopic tracers were performed to measure $\mathrm{N}$ uptake rates. In addition, shotgun metagenomic sequencing was carried out to characterize the taxonomic and functional profiles of bacterioplankton. Phytoplankton were the major contributors to $\mathrm{N}$ uptake and the results showed positive correlations between biovolumes of cyanobacteria and $\mathrm{NO}_{3}^{-}$uptake rates. Cyanobacteria predominated in the Itupararanga dam zone and were composed mainly by Raphidiopsis raciborskii. Moreover, the metagenomic analysis showed that Nostocaceae had a high genetic potential to drive $\mathrm{N}$-fixation and a high abundance of genes encoding nitrate transport proteins. The most abundant families of heterotrophic bacteria were Burkholderiaceae and Comamonadaceae, which were associated with the process of ammonium assimilation, ammonification, and denitrification. However, in both reservoirs the microbial community showed low genetic potential for denitrification and genes related to nitrification were not detected. A strong correlation was observed between Mycobacteriaceae and Nostocaceae, which encourages further studies to investigate these dynamics. The composition of the phytoplankton and bacterial communities were influenced by conductivity, nitrate, PT, DOC. We conclude that cyanobacteria play a key role in nitrogen metabolism and that the integrated analysis between bacterioplankton and phytoplankton is necessary and recommended for a better understanding of the aquatic microbial metabolic dynamics.
\end{abstract}

Key words: Cyanobacteria, metagenomic, uptake, nitrate, ammonium 


\section{Introduction}

Reservoirs are artificial freshwater ecosystems, built mainly for hydroelectricity production and for drinking water supply (Silva et al., 2014; Barros et al., 2019). They can also be used for irrigation and recreation (Decol et al., 2017; Hogeboom, Knook and Hoekstra, 2018). These multiple uses have been threatened due to nutrient enrichment of water, which may promote shifts in microbial communities (Barros et al., 2019) and interfere in the biogeochemical cycles dynamics (Cotner and Biddanda, 2002).

Inefficient wastewater treatment discharges and fertilizer runoff are the main responsible for the increase of nutrients phosphorus $(\mathrm{P})$ and nitrogen $(\mathrm{N})$ in freshwater environments (Childers et al. 2011; Paerl and Paul, 2012). Nitrogen is essential for the growth of phytoplankton and bacterioplankton (Glober et al., 2016) with studies indicating that the composition of these communities is strongly related to the type of dissolved inorganic nitrogen (DIN), mainly available on the forms of nitrate $\left(\mathrm{NO}_{3}{ }^{-}\right)$and ammonium $\left(\mathrm{NH}_{4}{ }^{+}\right)$(Donald et al., 2011; Glibert et al., 2016; Andersen et al., 2019; Kleinteich et al., 2020).

Traditionally, phytoplankton members were considered the major contributors for the $\mathrm{N}$ uptake in aquatic environments (Zehr and ward, 2002; Zehr et al., 2011). However, recent studies have reported that heterotrophic bacteria can also contribute significantly to this process in temperate marine and estuary environments environments (Kirchman and Wheeler, 1998; Bradley et al., 2010; Yuan et al., 2012; Trottet et al., 2016), however there are few measurements in freshwater environments, especially in subtropical and tropical zones. Heterotrophic bacteria may also be involved in other metabolic pathways of $\mathrm{N}$ in aquatic environments, such as nitrification, ammonification, denitrification and nitrogen fixation (for cases of diazotrophic bacteria) (Zehr and ward, 2002; Delmont., 20018; Deng et al., 2020).

The expansion of knowledge about bacterial diversity and their roles on the metabolism of biogeochemical cycles occurred due to the development of new molecular tools, such as metagenomic analysis (Sharpton, 2014; Roumpeka et al., 2017). Currently, this approach has been widely used to answer questions like "who's there?" and "what are they able to do?" (Grossart et al., 2020). However, most of the available studies regarding taxonomy and functional roles of microorganisms are concentrated in temperate areas (Mohiuddin et al., 2017; Chopyk et al., 2020; Fasching et al., 2020; Llorens-Marès et al., 2020), with a limited number of researches carried out in tropical environments (Meneghine et al., 2017; Deng et al., 2020). 
Tropical environments differ from temperate ones mainly due to higher temperatures and greater incidence of solar radiation with both characteristics presenting low amplitude of variation during the year (Lewis, 2000). Temperature and solar incidence, combined with the availability of nutrients, have direct impacts on microbial metabolic dynamics in tropical and subtropical zones (Lewis, 2010). Therefore, studies in these areas are important to provide information for future actions to control the impacts caused by eutrophication.

Given the importance of microbial communities to the $\mathrm{N}$ metabolism and vice versa, this study aimed to: (1) characterize the composition of phytoplankton and bacterial communities with microscopic analysis and shotgun metagenomic sequencing, respectively; (2) investigate the dynamics of $\mathrm{N}$ uptake by microbial communities measuring $\mathrm{NO}_{3}{ }^{-}$and $\mathrm{NH}_{4}{ }^{+}$uptake rates through experiments with ${ }^{15} \mathrm{~N}$ isotope tracers; (3) investigate functional profiles tracking genes associated with $\mathrm{N}$ metabolism in metagenomic data. We hypothesized that (1) phytoplankton are the major contributors to nitrogen assimilation and (2) heterotrophic bacteria have functional potential in many pathways in the nitrogen metabolism.

\section{Materials and methods}

\section{Study area and sample collection}

The Lobo and Itupararanga reservoirs are located in southeastern Brazil (Figure 2-1). The climate of this region is of the Cwa type (köppen classification), with annual average temperature of $20-22{ }^{\circ} \mathrm{C}$, a typical rainy season (October to March) and a dry season (April to September) (Pereira et al 2008; Pavão et al 2017; Beghelli et al., 2016). Morphometric characteristics from two reservoirs was described in Frascareli et al., (2018). 


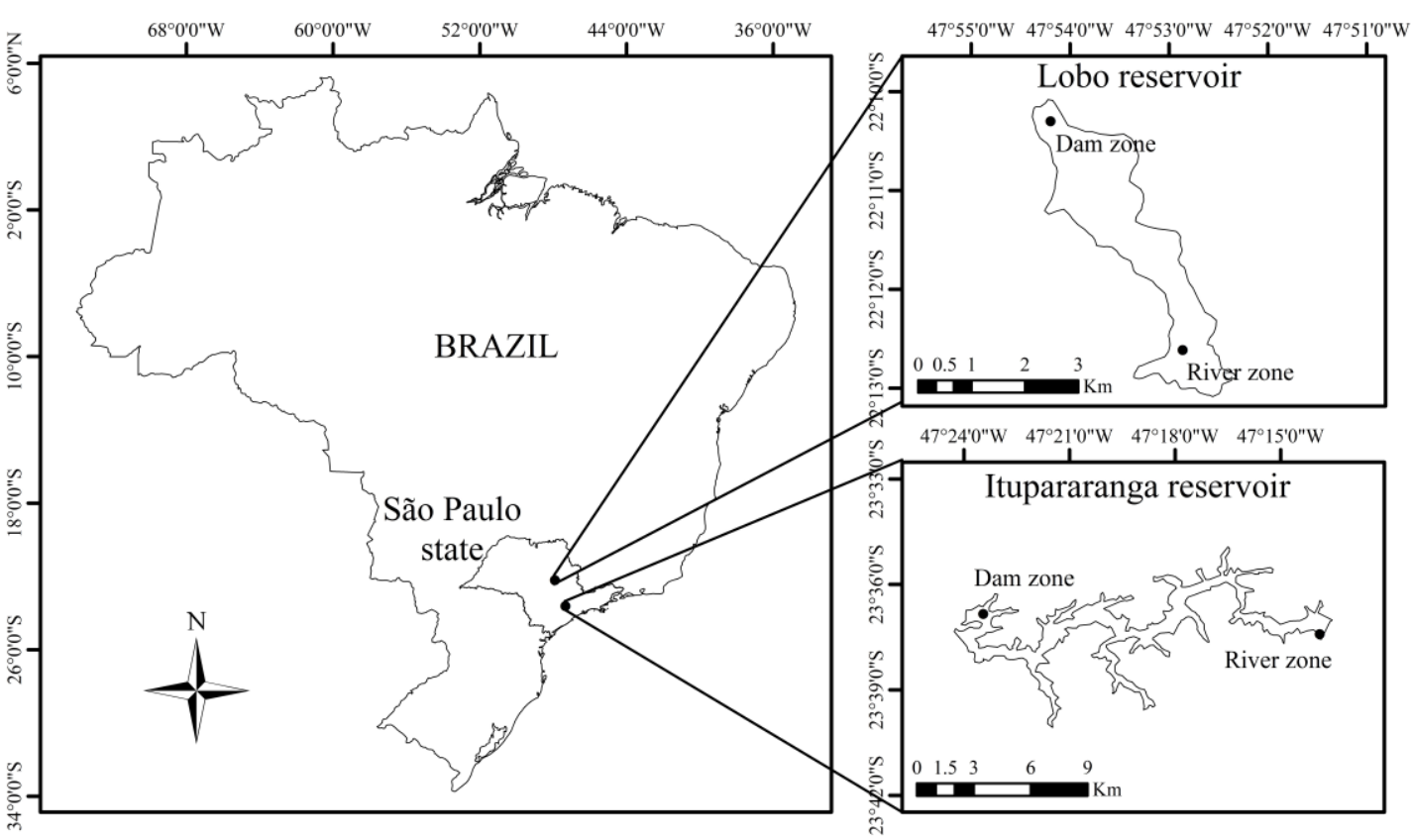

Figure 2-1. Map showing the location of the Itupararanga and Lobo reservoirs with sampling sites (dam zone and river zone).

In both reservoirs, previous studies have reported continuous degradation of water quality due to the increase of trophic state over the years. The Itupararanga reservoir was classified as oligo-mesotrophic until 2008, however there was a continuous increase in nutrients since then, and currently this reservoir is meso-eutrophic, with a tendency to become hypertrophic in the next years (Beghelli et al., 2016). Similar patterns occurred in the Lobo reservoir, which have reached meso-eutrophic or super-trophic conditions lately (Tundisi et al 2015; Frascareli et al 2018). This eutrophication process is related to the runoff of fertilizers used in agricultural lands along the drainage basin. In addition, the release of inadequate wastewater treatment also contributes to the enrichment of nutrients in these ecosystems (Rivera et al 2007; Simonetti et al 2019).

Water samples were collected from the subsurface with the Van Dorn bottle at different periods throughout the year, in May/2017 (autumn), August/2017 (winter), October/2017 (spring) and January/2018 (summer). In each reservoir, two collection sites were established, one with lotic characteristics (river zone) and another with lentic characteristics (dam zone). Phytoplankton samples were immediately fixed with acetic Lugol and stored in a dark place until counting. Bacterial samples were fixed with formalin buffered with borax (1\% final concentration) and then frozen at $-80^{\circ} \mathrm{C}$ until analysis. The water samples were immediately filtered on Macherey-Nagel GF-3 filters 
for analysis of dissolved nutrients and chlorophyll a $(\mathrm{Chl} a)$, and raw water samples were separated to access the total phosphorus (PT) and total Kjeldahl nitrogen (TKN). For metagenomic analyses water samples were filtered through a membranes with $0.22 \mu \mathrm{m}$ (Whatman® Nucleopore) and then stored at $-80{ }^{\circ} \mathrm{C}$.

\section{Environmental analyses}

Water temperature, dissolved oxygen (DO) concentration, and electric conductivity were measured in situ with multiparameter probe (HANNA®, model HI 9829). The dissolved nutrients, nitrate $\left(\mathrm{NO}_{3}^{-}\right)$, nitrite $\left(\mathrm{NO}_{2}^{-}\right)$, and soluble reactive phosphorus (SRP) were determined following methods described in APHA (2004). Ammonium was analyzed according to Koroleff (1976) and dissolved organic carbon (DOC) was estimated with a carbon analyzer (Shimadzu SSM 5000). Ammonium, nitrate, and nitrite concentrations were summed to estimate dissolved inorganic nitrogen (DIN). Total nutrients, such as total phosphorus (PT) and total Kjeldahl nitrogen (TKN), were estimated with raw water, using methods proposed in APHA (2004). With the sum of TKN, nitrate, and nitrite concentrations total nitrogen (NT) was obtained, and then molar ratios of NT: PT were calculated. The trophic state index was calculated following recommendations in Cunha, Calijuri and Lamparelli (2013).

Chl- $a$ was extracted with $80 \% \mathrm{v} / \mathrm{v}$ ethanol and the concentrations were determined according to Nuch (1980). Phytoplankton were quantified with sedimentation chambers (Uthermol, 1958) using an inverted microscope (Olympus CK2®). At least 20 individuals from the most abundant taxa $(>10 \%)$ were measured to access cell volume to calculated biovolume $\left(\mathrm{mm}^{3} \mathrm{~L}^{-1}\right)$ (Hillebrand et al., 1999; Sun and Liu, 2003). The cell volume of the taxa with less than $10 \%$ in abundance were obtained from the literature (Fonseca et al., 2014).

To estimate the abundance (cell. $\mathrm{mL}^{-1}$ ) of heterotrophic bacteria (HB) fluorescent beads ( $1 \mu \mathrm{m}$, Fluoresbrite carboxylate microspheres, Polysciences Inc., Warrington, PA, USA) and SYTO-13 dye (Molecular Probes; $2.5 \mu \mathrm{mol} \mathrm{L}^{-1}$ final concentration) were added to subsamples of water (Mansano et al 2017; Segovia et al 2018). These samples were processed in a FACSCalibur flow cytometer (Becton \& Dickinson Franklin Lakes, NJ, U.S.A.), following recommendations by Sarmento et al (2008). HB detection was performed plotting side scatter (SSC) versus FL1 (green fluorescence) and the FlowJo software was used for data processing (Segovia et al., 2018). 
Nitrogen uptake experiments by total community

Experiments were performed in both sampling sites (river and dam zone) from the Itupararanga and Lobo reservoirs. Measurements of ${ }^{15} \mathrm{~N}_{-} \mathrm{NH}_{4}{ }^{+}$and ${ }^{15} \mathrm{~N}-\mathrm{NO}_{3}{ }^{-}$uptake were performed separately. Water samples from the subsurface were collected in triplicate and stored in polycarbonate bottles $(0.5 \mathrm{~L})$ containing ${ }^{15} \mathrm{NH}_{4} \mathrm{Cl}$ or $\mathrm{Na}^{15} \mathrm{NO}_{3}$. The ${ }^{15} \mathrm{~N}$ substrates were added to the bottles at fixed concentrations $\left({ }^{15} \mathrm{NH}_{4} \mathrm{Cl}: 0.71 \mu \mathrm{mol} . \mathrm{L}^{-1}\right.$; $\mathrm{Na}^{15} \mathrm{NO}_{3:} 2.50 \mu \mathrm{mol} . \mathrm{L}^{-1}$ ).

The experimental bottles were incubated in situ (water subsurface) for $1 \mathrm{~h}$. At the end of incubation, water samples $(90-100 \mathrm{~mL})$ were filtered onto $25 \mathrm{~mm}$ Macherey-Nagel $\mathrm{GF} / 5$ filters $(0,4 \mu \mathrm{m}$ porosity). With this process, phytoplankton and bacteria were retained onto GF/5 filters and we were able to access the total $\mathrm{N}$ uptake rate of the microbial community. To access only bacterial uptake, we pre-filtered water samples on filters with $1.0 \mu \mathrm{m}$ porosity (Whatman ${ }^{\circledR}$ Nucleopore) and then onto GF/5 filters.

All GF/5 filters were dried at $40{ }^{\circ} \mathrm{C}$ for 24 hours and encapsulated with tin capsules until analysis. The ${ }^{15} \mathrm{~N}$ atom $\%$ and particulate organic nitrogen (PON) were analyzed with a mass spectrometer (Thermo Delta V) interfaced to an elemental analyzer (NC2500).

The nitrate $\left(\mathrm{NO}_{3}{ }^{-}\right)$and ammonium $\left(\mathrm{NH}_{4}^{+}\right)$uptake rates in nmol N L${ }^{-1} \mathrm{~h}^{-1}$ were determined according to the equations proposed by Dugdale and Wilkerson (1986). To obtain total $\mathrm{N}$ uptake, we added the $\mathrm{NO}_{3}{ }^{-}$and $\mathrm{NH}_{4}{ }^{+}$uptake rates.

\section{DNA extraction and Shotgun metagenomic sequencing}

Metagenomic sequencing was performed with samples of May/2017 and January/2018 taken from both sites of the Itupararanga and Lobo reservoirs. These samples were selected due to detection of microcystin and saxitoxin, in Lobo and Itupararanga (personal communication from Moraes, in progress), respectively.

DNA extraction was performed directly from the filters with a DNeasy PowerWater Kit (QIAGEN, Hilden, Germany) according to the manufacturer's instructions. The integrity of the extracted DNA was analyzed by electrophoresis on agarose gel $(1 \% \mathrm{w} / \mathrm{v})$ and the quantification was performed with fluorescence spectroscopy using a Qubit dsDNA HS assay kit (Thermo Fisher Scientific, Carlsbad, CA, United States).

Shotgun metagenomic libraries of each sample (2 reservoirs x 2 sites x 2 months x 2 replicates $=$ totaling 16 samples) were prepared with a Nextera XT DNA Sample 
Preparation Kit (Illumina, Inc., San Diego, CA, USA) following the manufacturer's instructions. The DNA libraries were quantified by realtime PCR, using the KAPA Library Quantification Kit for Illumina (KAPA Biosystems, Wilmington, DE, USA). Sequencing was carried out on a HiSeq 2500 platform (Illumina, Inc., San Diego, CA, USA) using the paired-end read length of $2 \times 100 \mathrm{bp}$.

\section{Sequence analysis}

After sequencing, the reads were paired using PEAR 0.9.5 (Zhang et al., 2014) and the quality was analyzed with FastQC (Andrews, 2010). The paired sequences of each sample were submitted to the MG-RAST server (Meyer et al 2008) using default sequence quality thresholds.

Taxonomic and functional analyses was performed using, respectively, NCBI RefSeq database and SEED subsystems (Overbeek et al., 2005), both available on the MG-RAST Server. The metagenomic sequences were compared to each database using an e-value of $1 \mathrm{e}-5$, an $80 \%$ minimal percent identity and a minimum alignment length of 25 bp. (Cai et al., 2016; Meneghine et al., 2017). The taxonomic identities of the metagenomic sequences related to nitrogen metabolism were performed with NCBI RefSeq database, using the same threshold described above.

\section{Statistical analyses}

All abiotic and biotic data, except $\mathrm{pH}$, were transformed in $\log (\mathrm{x}+1)$ to perform the analyses. The relationship between $\mathrm{N}$ uptake rates, abiotic variables, and phytoplankton composition was analyzed with the Spearman correlation, using a significance level of $p<0.05$. Correlations between relative abundance of bacterial groups and phytoplankton were also accessed.

The influence of environmental variables on phytoplankton and bacterioplankton was evaluated using distance-based redundancy analyses (db-RDA), for each community, separately (Legendre and Legendre, 1998). The collinearity between environmental variables was evaluated with variance inflation factors (VIF) and variables with VIF > 2.5 were removed from db-RDA (Legendre and Legendre, 1998). We tested the significance of db-RDA models with ANOVA and all statistical analyses described above were performed with $\mathrm{R}$, version 3.6.2 (R Core Team, 2016).

To compare the abundance of functional genes across metagenomic samples, we used the software package Statistical Analysis of Metagenomic Profiles, known as STAMP (Parks and Beiko, 2010). The significant differences between two groups 
(temporal or spatial) were identified using two-sided Welch's t-test (Bluman, 2007) and the Benjamini-Hochberg FDR correction (Benjamini and Hochberg, 1995).

\section{Results}

\section{Limnological characterization}

Table 2-1 shows the results of limnological characterization. The water temperature of the Itupararanga reservoir varied from $16.1^{\circ} \mathrm{C}(\mathrm{Aug} / 2017)$ to $25.2^{\circ} \mathrm{C}$ ( $\mathrm{Jan} / 2018)$ and in Lobo the variation was from $18.5^{\circ} \mathrm{C}(\mathrm{Aug} / 2017)$ to $25.0^{\circ} \mathrm{C}(\mathrm{Jan} / 2018)$. The $\mathrm{pH}$ ranged from 6.5 to 7.1 and from 6.0 to 8.7 , in the Itupararanga and Lobo reservoirs, respectively. The conductivity was higher in Itupararanga (63 to $94 \mu \mathrm{S} \mathrm{cm}^{-1}$ ) when compared to Lobo (13 a $\left.30 \mu \mathrm{S} \mathrm{cm} \mathrm{cm}^{-1}\right)$. The lowest DO concentration $\left(4.0 \mathrm{mg} \mathrm{L}^{-1}\right)$ occurred in the Itupararanga river zone (May/2017). DIN concentrations were mainly composed of nitrate, and both variables were higher in the samples from the river zone. In contrast, the ammonium concentrations were low in all samples, with a maximum value of $10.3 \mu \mathrm{mol} \mathrm{L}-1$. TKN ranged from 1.6 to $28.6 \mu \mathrm{mol} \mathrm{L}^{-1}$ in Itupararanga and from 4.0 to $27.4 \mu \mathrm{mol} \mathrm{L}{ }^{-1}$ in Lobo (in Jan/2018 the concentration was not detected). Low values of nitrite $(<1.0 \mu \mathrm{mol} \mathrm{L}-1)$ and $\mathrm{RSP}\left(<0.2 \mu \mathrm{mol} \mathrm{L}^{-1}\right)$ were detected in both reservoirs. TP concentrations were higher in the river zone, mainly in Itupararanga, where we observed the lowest TN:TP molar ratios. However, in almost all other samples, the TN:TP ratios were greater than 50:1, indicating P limitation. Generally, Itupararanga had higher Chl- $a$ concentrations, reaching $74.4 \mu \mathrm{g} \mathrm{L}^{-1}$ in the river zone sample from Oct/2017. The greatest abundance of heterotrophic bacteria was observed in Itupararanga, reaching $2.62 \times 10^{6}$ cell. $\mathrm{ml}^{-1}$ in the river zone. Both reservoirs were classified as mesotrophic, except the river zone from Itupararanga, which was classified as eutrophic. 
Table 2-1. Physical, chemical and biological variables of water in Itupararanga and Lobo reservoirs.

\begin{tabular}{|c|c|c|c|c|c|c|c|c|}
\hline \multicolumn{9}{|c|}{ Itupararanga reservoir } \\
\hline \multirow[b]{2}{*}{ Variables } & \multicolumn{4}{|c|}{ River zone } & \multicolumn{4}{|c|}{ Dam zone } \\
\hline & May/2017 & Aug/2017 & Oct/2017 & Jan/2018 & May/2017 & Aug/2017 & Oct/2017 & Jan/2018 \\
\hline Temp. $\left({ }^{\circ} \mathrm{C}\right)$ & 18.3 & 16.1 & 22.7 & 25.2 & 20.2 & 17.4 & 23.2 & 24.7 \\
\hline pH & 6.5 & 6.5 & 7.0 & 7.0 & 7.0 & 7.1 & 6.8 & 6.7 \\
\hline Cond. $\left(\mu \mathrm{S} \mathrm{cm}^{-1}\right)$ & 66.0 & 78.0 & 94.0 & 83.0 & 73.0 & 63.0 & 66.0 & 71.0 \\
\hline DO $\left(\mathrm{mg} \mathrm{L}^{-1}\right)$ & 4.0 & 8.5 & 7.7 & 8.1 & 7.4 & 8.6 & 6.9 & 7.5 \\
\hline TKN $\left(\mu \mathrm{mol} \mathrm{L}^{-1}\right)$ & $\begin{array}{c}4.6 \\
(2.6)\end{array}$ & $\begin{array}{l}26.7 \\
(5.0)\end{array}$ & $\begin{array}{c}5.9 \\
(7.6)\end{array}$ & $\begin{array}{c}28.6 \\
(21.8)\end{array}$ & $\begin{array}{c}8.5 \\
(5.1)\end{array}$ & $\begin{array}{l}20.6 \\
(0.9)\end{array}$ & $\begin{array}{c}1.6 \\
(1.6)\end{array}$ & $\begin{array}{c}4.2 \\
(1.1)\end{array}$ \\
\hline $\operatorname{DIN}\left(\mu \mathrm{mol} \mathrm{L} \mathbf{L}^{-1}\right)$ & $\begin{array}{l}57.4 \\
(0.4)\end{array}$ & $\begin{array}{l}55.6 \\
(0.3)\end{array}$ & $\begin{array}{l}55.5 \\
(0.3)\end{array}$ & $\begin{array}{l}68.4 \\
(0.7)\end{array}$ & $\begin{array}{l}40.1 \\
(0.8)\end{array}$ & $\begin{array}{l}26.3 \\
(0.2)\end{array}$ & $\begin{array}{c}25.9 \\
(0.05)\end{array}$ & $\begin{array}{l}23.1 \\
(0.4)\end{array}$ \\
\hline $\mathrm{NO}_{2}^{-}\left(\mu \mathrm{mol} \mathrm{L} \mathrm{L}^{-1}\right)$ & $\begin{array}{c}0.3 \\
(0.01)\end{array}$ & $\begin{array}{c}0.85 \\
(0.02)\end{array}$ & $\begin{array}{c}0.16 \\
(0.02)\end{array}$ & nd & nd & nd & $\begin{array}{c}0.15 \\
(0.01)\end{array}$ & nd \\
\hline $\mathrm{NO}_{3}^{-}\left(\mu \mathrm{mol} \mathrm{L} \mathbf{L}^{-1}\right)$ & $\begin{array}{l}56.0 \\
(0.4)\end{array}$ & $\begin{array}{l}50.2 \\
(0.3)\end{array}$ & $\begin{array}{l}53.1 \\
(0.4)\end{array}$ & $\begin{array}{l}66.9 \\
(0.4)\end{array}$ & $\begin{array}{l}29.8 \\
(0.8)\end{array}$ & $\begin{array}{l}23.8 \\
(0.4)\end{array}$ & $\begin{array}{l}25.7 \\
(0.1)\end{array}$ & $\begin{array}{l}23.1 \\
(0.4)\end{array}$ \\
\hline $\mathrm{NH}_{4}^{+}\left(\mu \mathrm{mol} \mathrm{L}{ }^{-1}\right)$ & $\begin{array}{c}1.1 \\
(0.03)\end{array}$ & $\begin{array}{c}4.5 \\
(0.05)\end{array}$ & $\begin{array}{c}2.2 \\
(0.1)\end{array}$ & $\begin{array}{c}1.5 \\
(0.3)\end{array}$ & $\begin{array}{c}10.3 \\
(0.04)\end{array}$ & $\begin{array}{c}2.5 \\
(0.1)\end{array}$ & nd & nd \\
\hline $\mathbf{T P}\left(\mu \mathrm{mol} \mathrm{L} \mathbf{L}^{-1}\right)$ & $\begin{array}{c}1.3 \\
(0.2)\end{array}$ & $\begin{array}{c}1.2 \\
(0.02)\end{array}$ & $\begin{array}{c}1.8 \\
(0.1)\end{array}$ & $\begin{array}{c}2.3 \\
(0.02)\end{array}$ & $\begin{array}{c}0.5 \\
(0.04)\end{array}$ & $\begin{array}{c}0.4 \\
(0.01)\end{array}$ & $\begin{array}{c}0.3 \\
(0.02)\end{array}$ & $\begin{array}{c}0.3 \\
(0.01)\end{array}$ \\
\hline $\operatorname{RSP}\left(\mu \mathrm{mol} \mathrm{L}^{-1}\right)$ & $<0.2$ & $<0.2$ & $<0.2$ & $<0.2$ & nd & nd & $<0.2$ & $<0.2$ \\
\hline $\operatorname{DOC}\left(\mathrm{mg} \mathrm{L}^{-1}\right)$ & $\begin{array}{c}6.3 \\
(0.6)\end{array}$ & $\begin{array}{c}2.9 \\
(0.1)\end{array}$ & $\begin{array}{c}5.0 \\
(0.1)\end{array}$ & $\begin{array}{c}7.7 \\
(0.2)\end{array}$ & $\begin{array}{l}3.6 \\
(0.3\end{array}$ & $\begin{array}{c}3.7 \\
(0.1)\end{array}$ & $\begin{array}{l}4.3 \\
(0.2)\end{array}$ & $\begin{array}{c}3.9 \\
(0.2)\end{array}$ \\
\hline TN:TP & $\begin{array}{l}46.8 \\
(7.1)\end{array}$ & $\begin{array}{l}62.3 \\
(3.2)\end{array}$ & $\begin{array}{l}33.3 \\
(5.2)\end{array}$ & $\begin{array}{l}42.2 \\
(9.2)\end{array}$ & $\begin{array}{c}78.9 \\
(17.7)\end{array}$ & $\begin{array}{l}122.2 \\
(7.6)\end{array}$ & $\begin{array}{l}82.4 \\
(5.8)\end{array}$ & $\begin{array}{l}81.6 \\
(4.1)\end{array}$ \\
\hline Chl- $a\left(\mu g^{-1}\right)$ & $2.3(0.6)$ & $18.1(1.8)$ & $74.4(6.3)$ & $9.9(8.6)$ & $21.7(0.3)$ & $22.7(2.0)$ & $17.1(0.6)$ & $20.7(1.0)$ \\
\hline PHY $\left(\mathrm{mm}^{3} \cdot \mathrm{L}^{-1}\right)$ & 0.7 & 4.2 & 27.7 & 2.6 & 3.0 & 4.8 & 5.2 & 3.5 \\
\hline HB $\left(10^{6}\right.$ cells.ml $\left.{ }^{-1}\right)$ & 1.10 & 1.50 & 0.55 & 2.62 & 2.12 & 0.75 & 1.35 & 1.33 \\
\hline \multicolumn{9}{|c|}{ Lobo reservoir } \\
\hline & \multicolumn{4}{|c|}{ River zone } & \multicolumn{4}{|c|}{ Dam zone } \\
\hline & May/2017 & Aug/2017 & Oct $/ 2017$ & Jan/2018 & May/2017 & Aug/2017 & Oct/2017 & Jan/2018 \\
\hline Temp. $\left({ }^{\circ} \mathrm{C}\right)$ & 21.4 & 18.6 & 21.4 & 23.8 & 22.3 & 18.5 & 22.6 & 25.0 \\
\hline pH & 8.7 & 7.2 & 6.1 & 6.3 & 7.1 & 6.4 & 6.0 & 6.0 \\
\hline Cond. $\left(\mu S \mathrm{~cm}^{-1}\right)$ & 15.0 & 17.0 & 16.0 & 30.0 & 14.0 & 13.0 & 14.0 & 26.0 \\
\hline DO $\left(\mathrm{mg} \mathrm{L}^{-1}\right)$ & 6.9 & 8.2 & 6.3 & 6.1 & 9.0 & 7.9 & 5.5 & 6.0 \\
\hline TKN $(\boldsymbol{\mu M})$ & $\begin{array}{c}9.6 \\
(5.1)\end{array}$ & $\begin{array}{c}9.8 \\
(12.6)\end{array}$ & $\begin{array}{c}8.6 \\
(2.6)\end{array}$ & $\begin{array}{c}4.0 \\
(3.8)\end{array}$ & $\begin{array}{l}13.3 \\
(4.8)\end{array}$ & $\begin{array}{l}27.4 \\
(3.3)\end{array}$ & $\begin{array}{c}9.5 \\
(2.1)\end{array}$ & nd \\
\hline DIN $(\boldsymbol{\mu M})$ & $\begin{array}{l}50.9 \\
(0.7)\end{array}$ & $\begin{array}{l}42.6 \\
(0.1)\end{array}$ & $\begin{array}{l}47.5 \\
(0.5)\end{array}$ & $\begin{array}{l}49.7 \\
(0.4)\end{array}$ & $\begin{array}{l}38.7 \\
(0.7)\end{array}$ & $\begin{array}{l}36.3 \\
(0.4)\end{array}$ & $\begin{array}{l}35.6 \\
(0.4)\end{array}$ & $\begin{array}{l}39.8 \\
(0.1)\end{array}$ \\
\hline $\mathrm{NO}_{2}^{-}(\mu \mathrm{M})$ & $\begin{array}{c}0.18 \\
(0.02)\end{array}$ & $\begin{array}{c}0.35 \\
(0.02)\end{array}$ & $\begin{array}{c}0.34 \\
(0.03)\end{array}$ & $\begin{array}{c}0.13 \\
(0.02)\end{array}$ & $\begin{array}{c}0.17 \\
(0.02)\end{array}$ & $\begin{array}{c}0.12 \\
(0.01)\end{array}$ & $\begin{array}{c}0.28 \\
(0.01)\end{array}$ & $\begin{array}{c}0.17 \\
(0.04)\end{array}$ \\
\hline $\mathrm{NO}_{3}^{-}(\mu \mathrm{M})$ & $\begin{array}{l}50.0 \\
(0.7)\end{array}$ & $\begin{array}{l}42.1 \\
(0.1)\end{array}$ & $\begin{array}{l}46.2 \\
(0.4)\end{array}$ & $\begin{array}{l}49.5 \\
(0.4)\end{array}$ & $\begin{array}{l}38.6 \\
(0.7)\end{array}$ & $\begin{array}{l}36.0 \\
(0.4)\end{array}$ & $\begin{array}{l}33.8 \\
(0.4)\end{array}$ & $\begin{array}{l}37.9 \\
(0.1)\end{array}$ \\
\hline $\mathrm{NH}_{4}{ }^{+}(\boldsymbol{\mu M})$ & $\begin{array}{c}0.7 \\
(0.2)\end{array}$ & $\begin{array}{c}0.1 \\
(0.1)\end{array}$ & $\begin{array}{c}1.0 \\
(0.6)\end{array}$ & nd & nd & $\begin{array}{c}0.2 \\
(0.05)\end{array}$ & $\begin{array}{c}1.5 \\
(0.05)\end{array}$ & $\begin{array}{c}1.8 \\
(0.1)\end{array}$ \\
\hline $\mathbf{T P}(\boldsymbol{\mu M})$ & $\begin{array}{c}0.6 \\
(0.02)\end{array}$ & $\begin{array}{c}0.7 \\
(0.04)\end{array}$ & $\begin{array}{c}1.1 \\
(0.02)\end{array}$ & $\begin{array}{c}0.7 \\
(0.06)\end{array}$ & $\begin{array}{c}0.5 \\
(0.03)\end{array}$ & $\begin{array}{c}0.5 \\
(0.08)\end{array}$ & $\begin{array}{c}0.6 \\
(0.03)\end{array}$ & $\begin{array}{c}0.7 \\
(0.02)\end{array}$ \\
\hline $\operatorname{RSP}(\boldsymbol{\mu M})$ & $<0.2$ & nd & $<0.2$ & $<0.2$ & $<0.2$ & nd & nd & $<0.2$ \\
\hline DOC $\left(\mathrm{mg} \mathrm{L}^{-1}\right)$ & $\begin{array}{c}5.7 \\
(0.1)\end{array}$ & $\begin{array}{c}3.8 \\
(0.1)\end{array}$ & $\begin{array}{c}4.3 \\
(0.1)\end{array}$ & $\begin{array}{c}4.8 \\
(0.1)\end{array}$ & $\begin{array}{c}4.4 \\
(0.1)\end{array}$ & $\begin{array}{c}3.6 \\
(0.1)\end{array}$ & $\begin{array}{c}3.3 \\
(0.1)\end{array}$ & $\begin{array}{l}4.0 \\
(0.1)\end{array}$ \\
\hline TN:TP & $\begin{array}{l}93.6 \\
(6.1)\end{array}$ & $\begin{array}{c}69.3 \\
(16.1)\end{array}$ & $\begin{array}{l}47.9 \\
(2.4)\end{array}$ & $\begin{array}{c}74.6 \\
(11.2)\end{array}$ & $\begin{array}{l}101.4 \\
(16.1)\end{array}$ & $\begin{array}{l}129.4 \\
(24.8)\end{array}$ & $\begin{array}{l}76.6 \\
(6.0)\end{array}$ & $\begin{array}{l}51.9 \\
(1.3)\end{array}$ \\
\hline Chl $a\left(\mu \mathrm{g} \mathrm{L}^{-1}\right)$ & $8.2(0.6)$ & $5.6(1.1)$ & $8.6(1.5)$ & $8.9(1.7)$ & $17.8(1.0)$ & $8.9(1.0)$ & $3.0(2.0)$ & $8.2(1.1)$ \\
\hline PHY $\left(\mathrm{mm}^{3} \cdot \mathrm{L}^{-1}\right)$ & 1.0 & 1.2 & 2.6 & 0.4 & 3.6 & 4.9 & 1.0 & 0.8 \\
\hline HB $\left(10^{6}\right.$ cells.ml $\left.{ }^{-1}\right)$ & 1.59 & 1.76 & 1.07 & 0.75 & 1.44 & 1.32 & 0.64 & 0.54 \\
\hline
\end{tabular}

Temp. temperature; Cond. Conductivity; DO dissolved oxygen; TKN total Kjeldahl nitrogen; DIN dissolved inorganic nitrogen; $\mathrm{NO}_{2}{ }^{-}$nitrite; $\mathrm{NO}_{3}{ }^{-}$nitrate; $\mathrm{NH}_{4}{ }^{+}$ammonium; TP total phosphorus; $\mathrm{SRP}$ soluble reactive phosphorus; DOC dissolved organic carbon; NT:TP total nitrogen:total phosphorus ratio; nd non-detected, Chl chlorophyll; PHY Phytoplankton; HB heterotrophic bacteria. 


\section{Phytoplankton Dynamics}

The phytoplankton groups Bacillariophyceae, Chlorophyceae, Cryptophyceae, Cyanophyceae, and Dinophyceae were the main contributors to the total phytoplankton biovolume in the Itupararanga and Lobo reservoirs (Figure 2-2). Cyanophyceae, mainly composed by Raphidiopsis raciborskii (Figure 2-3), showed a high contribution to the total phytoplankton biovolume in all samples from the Itupararanga dam zone, ranging between 26.2\% (Aug/2017) and 69.5\% (Jan/2018). On the other hand, cyanobacteria were not representative $(0.3-6.8 \%)$ in the Lobo reservoir. The contribution of Bacillariophyceae in Itupararanga was high in the dam zone (15.5 to 50.0\%) and in the river zone (1.8 to 63.3\%). Total phytoplankton biovolume in the dam zone from Lobo was composed by Bacillarophyceae (72\% - oct/2017) and Dinophyceae (reaching $74.6 \%$ - May/2017). In the river zone of Itupararanga, the total phytoplankton biovolume (27.4 mm. $\mathrm{L}^{-1}$ - Table 2 -1) was mainly composed by dinoflagellate Ceratium furcoides $(88.3 \%)$ in Oct/2017. Chlorophyceae had a low contribution in both reservoirs, while Cryptophycea was more representative in the Lobo reservoir. Other phytoplankton groups, such as Chlamydophyceae, Chrysophyceae, Euglenophyceae, Trebouxiophyceae, Xanthophyceae, and Zygnemaphyceae were also counted in water samples from the studied reservoirs. 
River zone

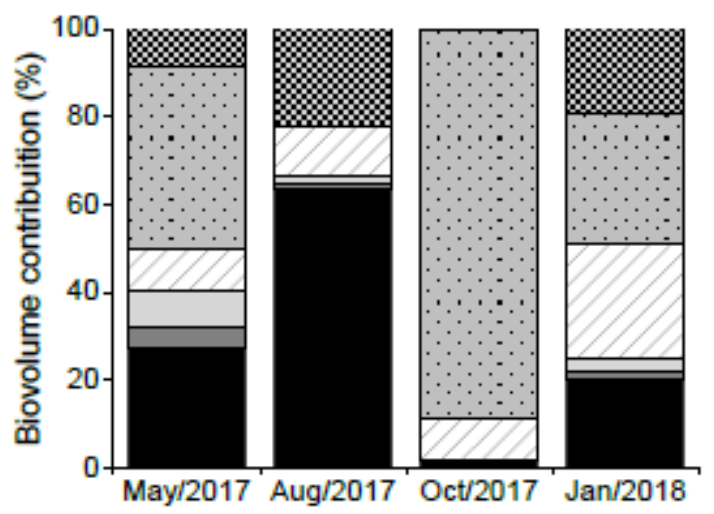

River zone

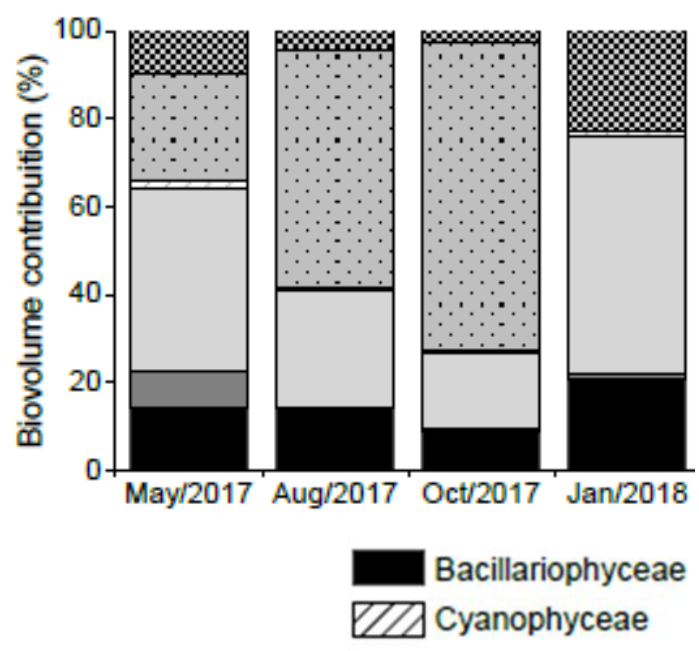

Dam zone

(A)

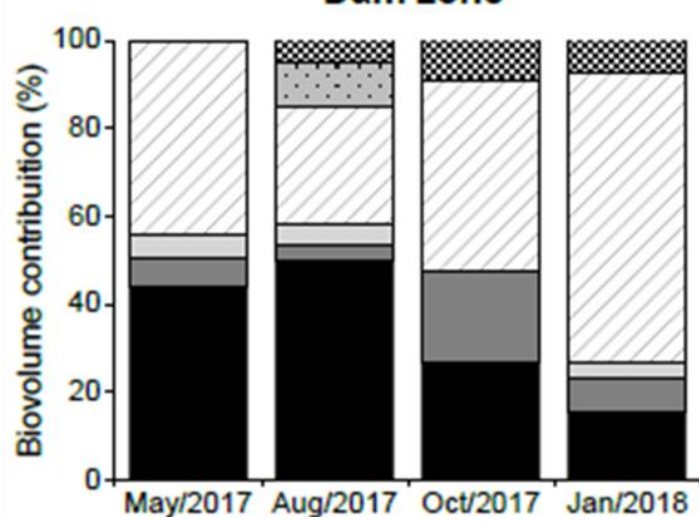

Dam zone

(B)

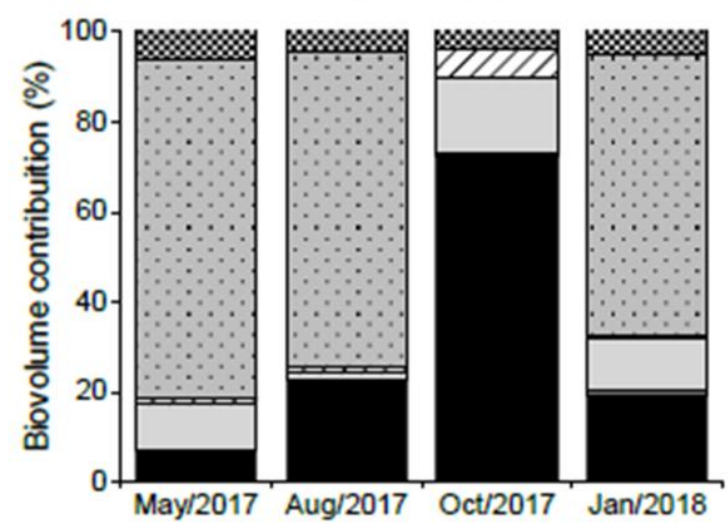

Chlorophyceae Dinophyceae
Cryptophyceae

Others

Figure 2-2. Biovolume contribution (\%) of phytoplankton classes in (A) the Itupararanga reservoir and in (B) the Lobo reservoir, in May/2017, August/2017, October/2017 and January/2018. Classes with biovolume below 5\% were presented in "Others". 
River zone

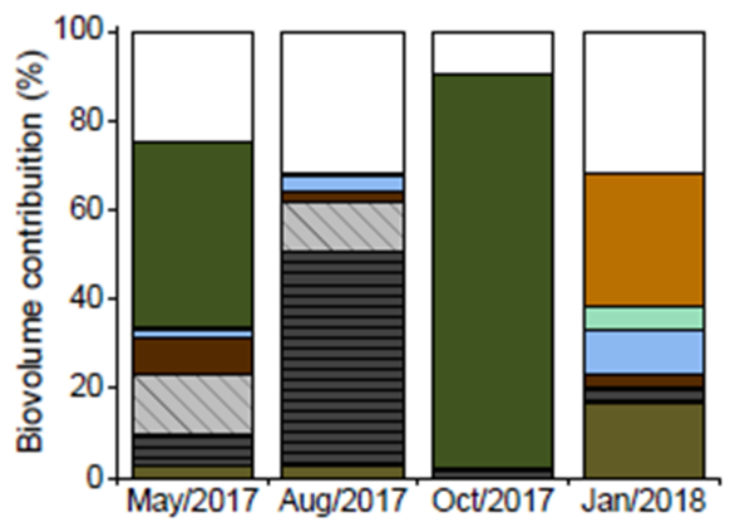

Dam zone

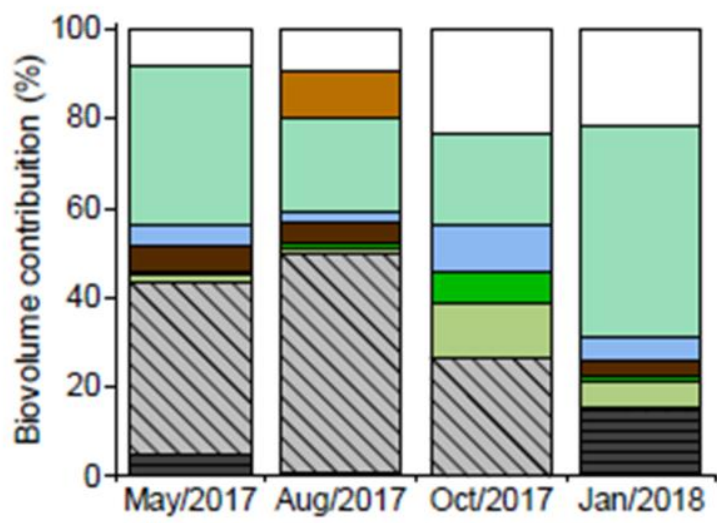

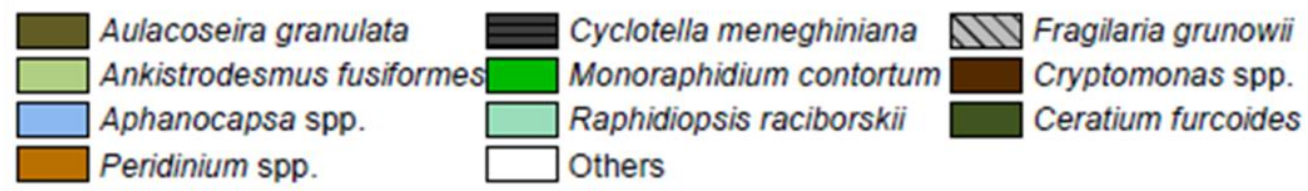

(A)

(B)

River zone

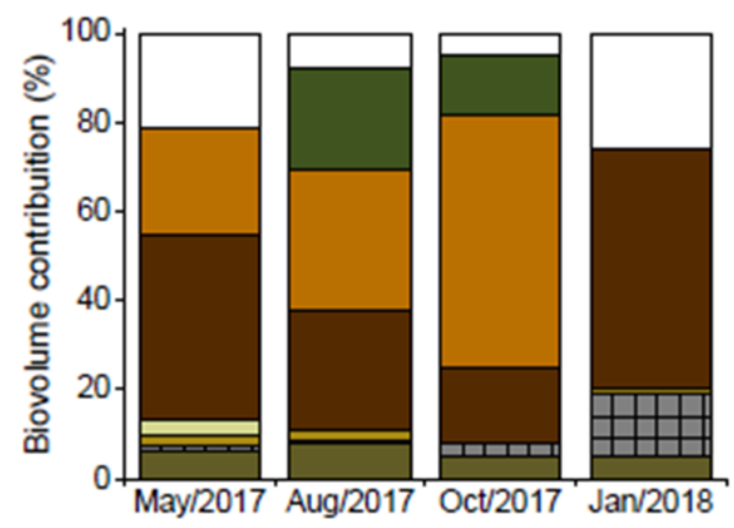

Dam zone

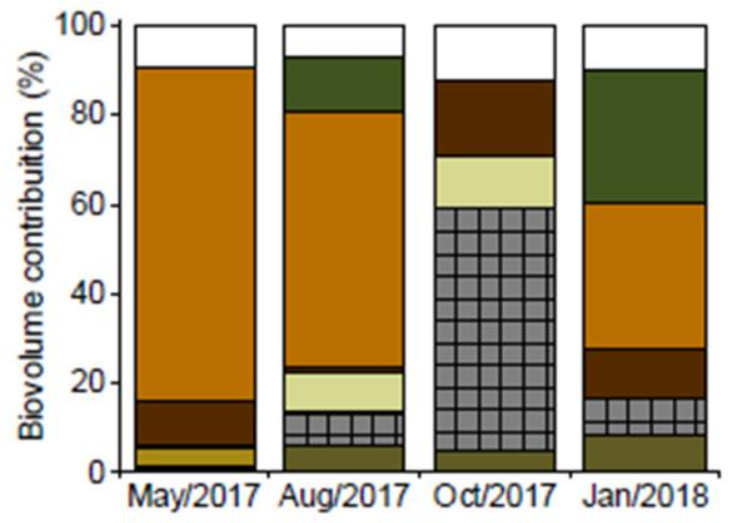

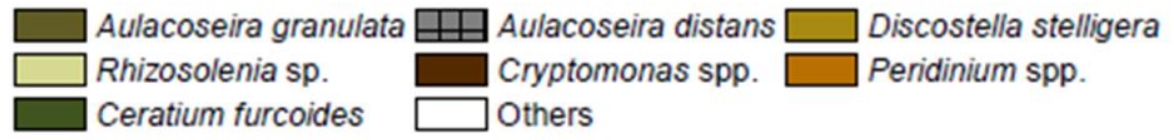

Figure 2-3. Biovolume contribution (\%) of the phytoplankton genera/species of (A) the Itupararanga reservoir and (B) teh Lobo reservoir, in May/2017, August/2017, October/2017 and January/2018. Classes with biovolume below $5 \%$ were presented in "Others".

The db-RDA model was performed with phytoplankton genera/species that had a biovolume above 5\% and with environmental variables that had VIF $<2.5$ (Figure 2-4). The model was significative $(\mathrm{p}<0.001)$ and the first two axes accounted for $71.9 \%$ of total variance between phytoplankton and environment variables relationship (CAP 1: 51.6\%; CAP 2: $20.1 \%$ ). Samples from Itupararanga (right side) and Lobo (left side) were grouped separately, on the opposite sides of the diagram. This result indicates a clear difference between phytoplankton composition in both reservoirs. Samples from the Itupararanga 
river zone were associated with high conductivity, whereas samples from the dam zone were related to Raphidiopsis raciborskii and Fragilaria grunowii, and with low nitrate, PT and DOC concentrations.

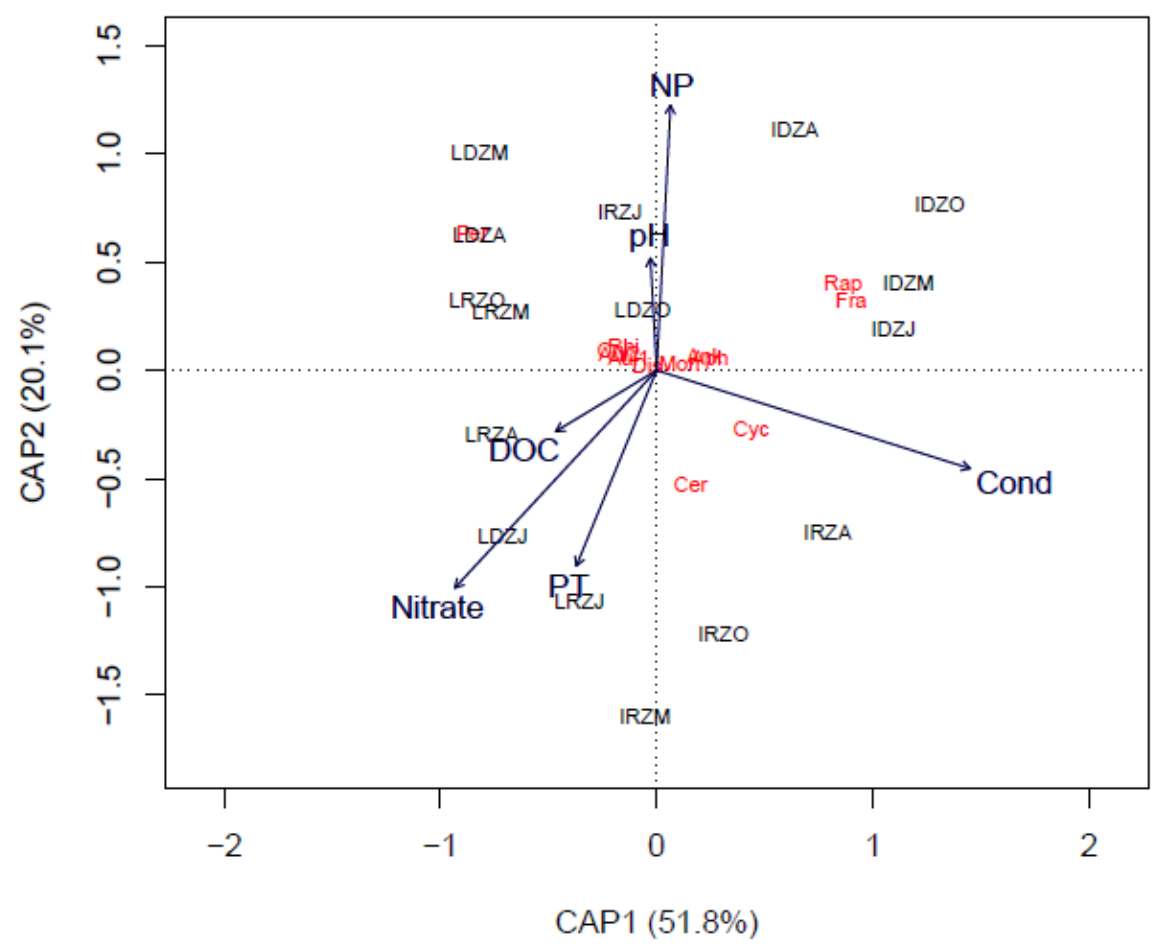

Figure 2-4. Distance-based redundancy analysis (db-RDA) between phytoplankton community composition and environmental variables. Abbreviations - I: Itupararanga reservoir; L: Lobo reservoir; DZ: dam zone; RZ: river zone; M: May/2017, J: January/2018; Temp: temperature; Cond: conductivity; DOC: dissolved organic carbon; NP nitrogen and phosphorus ratio; Ank: Ankistrodesmus fusiformes; Apha: Aphanocapsa sp.; Aul1 Aulacoseira granulata; Aul2: Aulacoseira distans; Cer: Ceratium furcoides; Cry: Cryptomonas sp.; Cyc: Cyclotella meneghiniana; Dis: Discotella stelligera; Fra: Fragilaria grunowii; Mono: Monoraphidium contortum; Per: Peridinium; Rap: Raphidiopsis raciborskii; Rhi: Rhizosolenia sp.

\section{Nitrogen uptake rates}

In both reservoirs, free-living heterotrophic bacteria $(<1.0 \mu \mathrm{m})$ exhibited low total $\mathrm{N}$ uptake rates, ranging from $0.5-9.0 \mathrm{nmol} \mathrm{N} \mathrm{L}{ }^{-1} \mathrm{~h}^{-1}$ and $0.5-7.7 \mathrm{nmol} \mathrm{N} \mathrm{L}^{-1} \mathrm{~h}^{-1}$, in Itupararanga and Lobo, respectively. The contribution of heterotrophic bacteria to $\mathrm{N}$ uptake varied between approximately $1 \%$ and 14\% (Figure 2-5). Therefore, N sources $\left(\mathrm{NO}_{3}{ }^{-}\right.$and $\left.\mathrm{NH}_{4}{ }^{+}\right)$were mainly taken up by phytoplankton in all samples (86.04-98.4\%). 


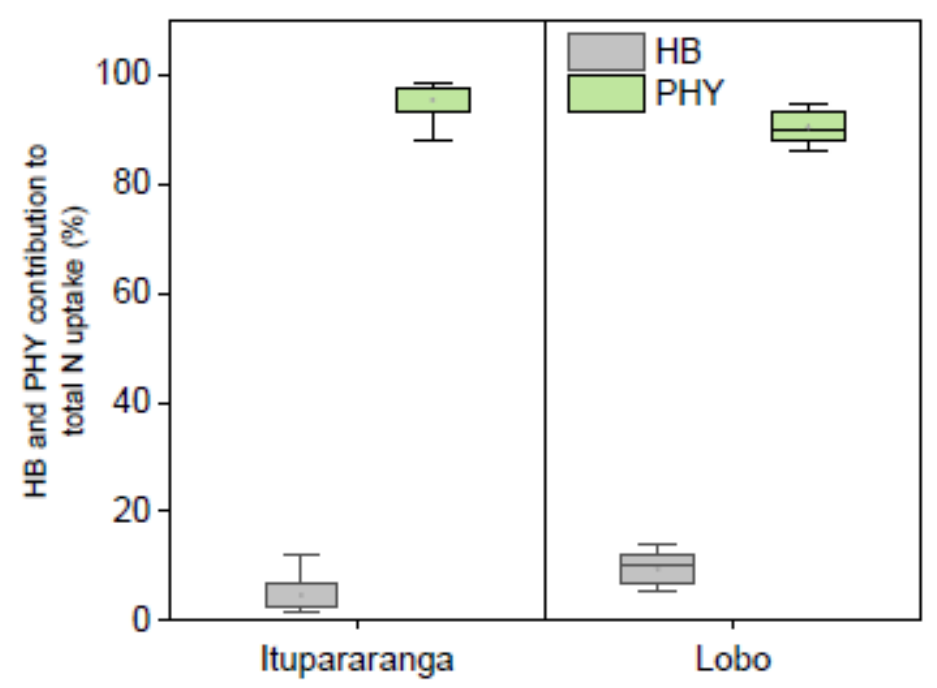

Figure 2-5. Contribution (\%) of heterotrophic bacteria (HB) and phytoplankton (PHY) to the total $\mathrm{N}$ uptake $\left(\mathrm{NO}_{3}{ }^{-}\right.$uptake $+\mathrm{NH}_{4}{ }^{+}$uptake). The figure displays a boxplot with the percentage calculated from all Itupararanga and Lobo experimental samples.

The $\mathrm{N}$ uptake rate by phytoplankton was calculated through measures without bacterial $\mathrm{N}$ uptake rate. The total $\mathrm{N}$ uptake $\left(\mathrm{NO}_{3}{ }^{-}\right.$uptake $+\mathrm{NH}_{4}{ }^{+}$uptake $)$by phytoplankton in the Itupararanga reservoir ranged from 10.1 to $568.8 \mathrm{nmol} \mathrm{N} \mathrm{L}^{-1} \mathrm{~h}^{-1}$ (Figure 2-6.A) while in the Lobo reservoir varied between 10.5 to $80.4 \mathrm{nmol} \mathrm{N} \mathrm{L}^{-1} \mathrm{~h}^{-1}$ (Figure 2-6. B).

Ammonium was the preferred $\mathrm{N}$ source used by phytoplankton in almost all samplings from the Lobo reservoir, accounting for $94.8 \%$ of the total $\mathrm{N}$ uptake in Jan/2018 (Table S2-1). The preference for ammonium was also detected in the dam zone from Itupararanga, except in Jan/2018, when the nitrate source was widely used by phytoplankton, raging $84.3 \%$ of the total $\mathrm{N}$ uptake (Table S2-1). In addition, the highest $\mathrm{NO}_{3}{ }^{-}$uptake (515.9 nmol N L${ }^{-1} \mathrm{~h}^{-1}$ ) accounted for $90 \%$ of total $\mathrm{N}$ uptake in the river zone, coinciding with the period (Oct/2018) when Ceratium bloom formation occurred.

Correlation analyses showed positive relationships between temperature and $\mathrm{NO}_{3}{ }^{-}$ uptake rate $(\mathrm{r}=0.48, \mathrm{p}<0.05), \mathrm{NH}_{4}{ }^{+}$uptake rate $(\mathrm{r}=0.77, \mathrm{p}<0.05)$, and total $\mathrm{N}$ uptake rate $\left(\mathrm{NO}_{3}{ }^{-}\right.$uptake $+\mathrm{NH}_{4}{ }^{+}$uptake: $\left.\mathrm{r}=0.75, \mathrm{p}<0.05\right)$. In addition, $\mathrm{NH}_{4}+$ uptake rates showed significant positive correlations with the biovolumes of Chlorophyceae $(0.40$, $\mathrm{p}<0.05)$, while $\mathrm{NO}_{3}{ }^{-}$uptake rates correlated with biovolumes of Cyanobacteria $(r=0.59$, $\mathrm{p}<0.05)$ and Dinophyceae $(\mathrm{r}=0.50, \mathrm{p}<0.05)$. 
(A)

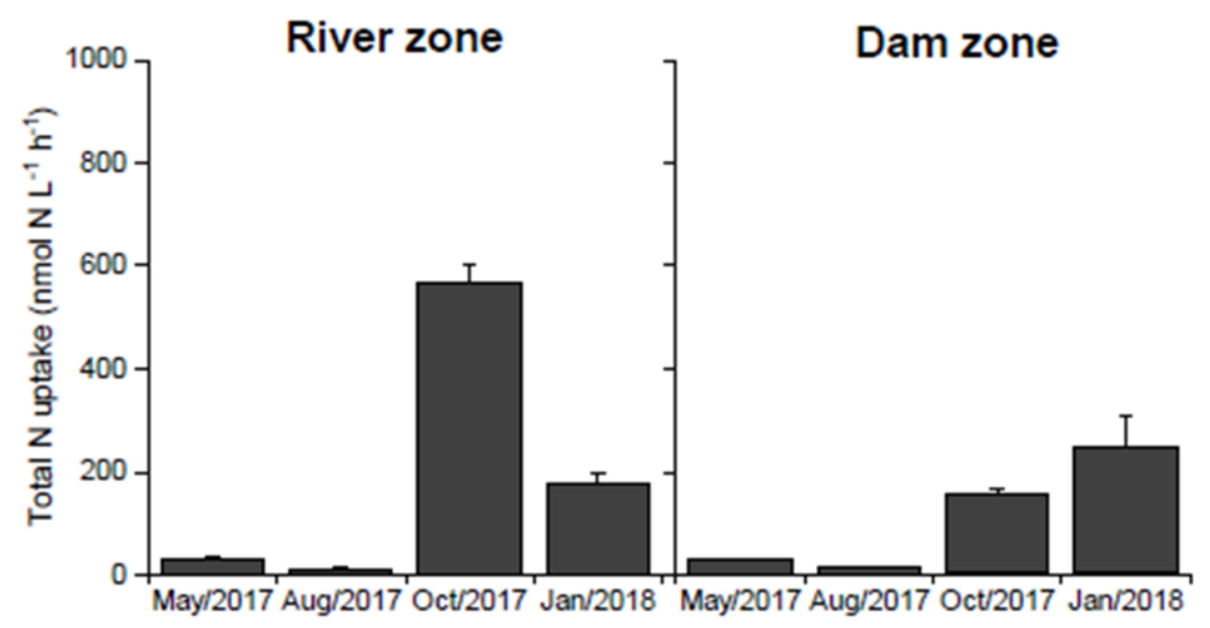

(B)

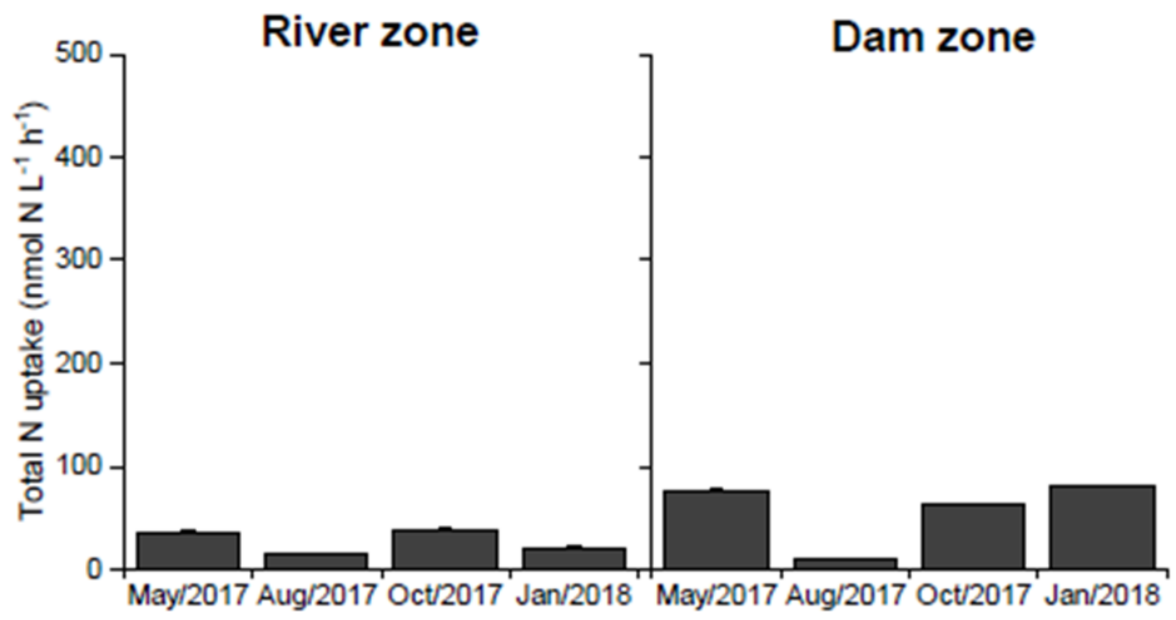

Figure 2-6. Total Nitrogen uptake rates (sum of $\mathrm{NO}_{3}{ }^{-}$uptake and $\mathrm{NH}_{4}{ }^{+}$uptake) in river zone and dam zone samples from the (A) Itupararanga reservoir and the (B) Lobo reservoir. Samples were collected in May/2017, August/2017, October/2018, and January/2018.

\section{Taxonomic characterization of bacterial communities}

The metagenomic sequencing yielded more than 23 million reads for each sample (Table S2-2). After quality control from the MG-RAST pipeline, an average of $22 \pm 5.6 \%$ short sequences and duplicates were removed. Taxonomic analysis of the metagenome showed that the domain Bacteria (90.63 - 98.11\%) predominated in all samples, followed by Eukaryota (1.67 - 6.95\%), Viruses (0.05 - 2.31\%) and Archaea (0.07 - 0.17\%) (Table S2-2).

In both reservoirs, Proteobacteria, Cyanobacteria, Actinobacteria, and Bacteroidetes were the most representative bacterial phyla, and together they accounted for $76.3 \%$ and $95.0 \%$ of the sequences annotated in the samples of Lobo and Itupararanga, 
respectively. Cyanobacteria were the most abundant phylum in the Itupararanga dam zone, whereas Proteobacteria was dominant in the river zone (Figure 2-7). Proteobacteria also dominated almost all samples from the Lobo reservoir except in May, when the relative abundance of Proteobacteria was approximately 38\%, Firmicutes $20 \%$ and Cyanobacteria 17\%. Planctomycetes and Verrucomicrobia phyla were less representative but showed relative abundance above $1 \%$ in at least one of the samples.
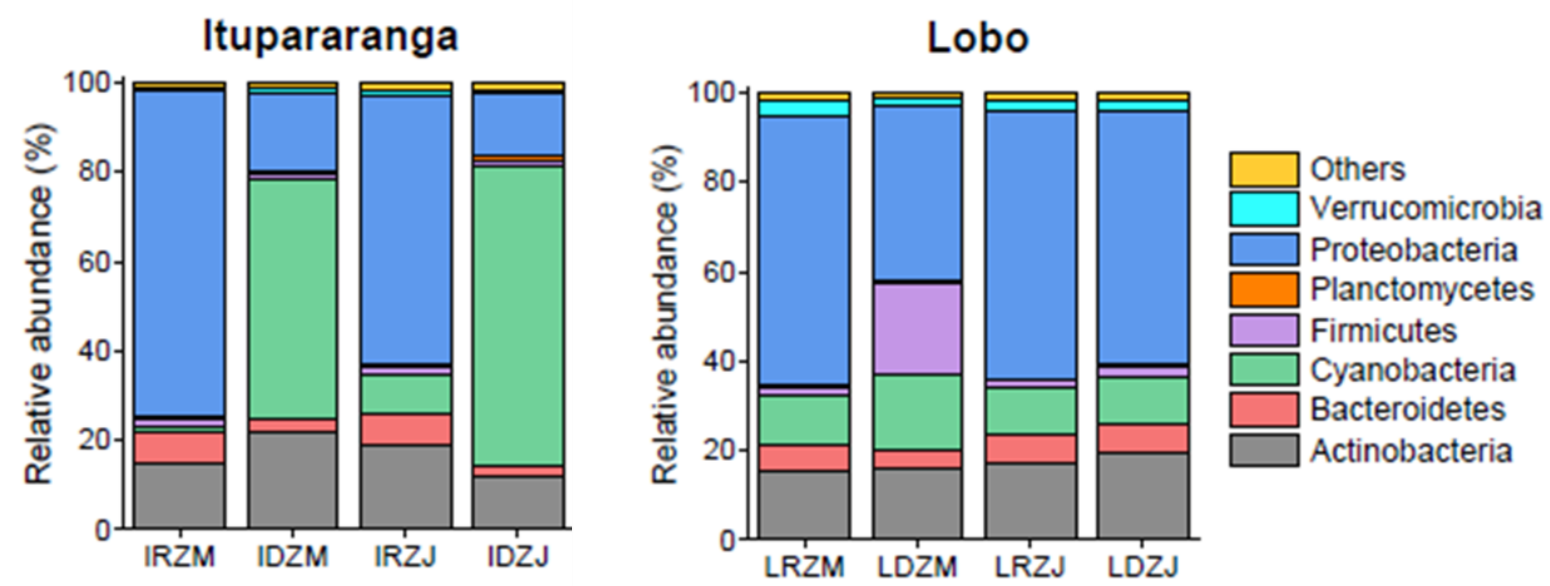

Figure 2-7. Relative abundance (\%) of bacterial phyla in water samples collected in the river zone (RZ) and in the dam zone (DZ) from the Itupararanga (I) and Lobo (L) reservoirs, in May/2017 (M) and January/2018 (J). "Others" represent phyla with less than 1\% of abundance

At family level, Cyanobacteria were composed mainly by the family Nostocaceae in the dam zone of the Itupararanga reservoir (Figure 2-8), while unclassified families derived from the order Chroococcales presented low relative abundance in both reservoirs, varying from 0.6 to $7.8 \%$ in Itupararanga and from 6.9 to $11.1 \%$ in Lobo. Burkholderiaceae and Comamonadaceae were the most abundant families of Proteobacteria, and the least representative were Methylophilaceae, Enterobacteriaceae, and Rhodocyclaceae. Actinobacteria was represented mainly of Mycobacteriaceae and Streptomycetaceae, while the most representative family of Bacteroidetes was Flavobacteriaceae. 


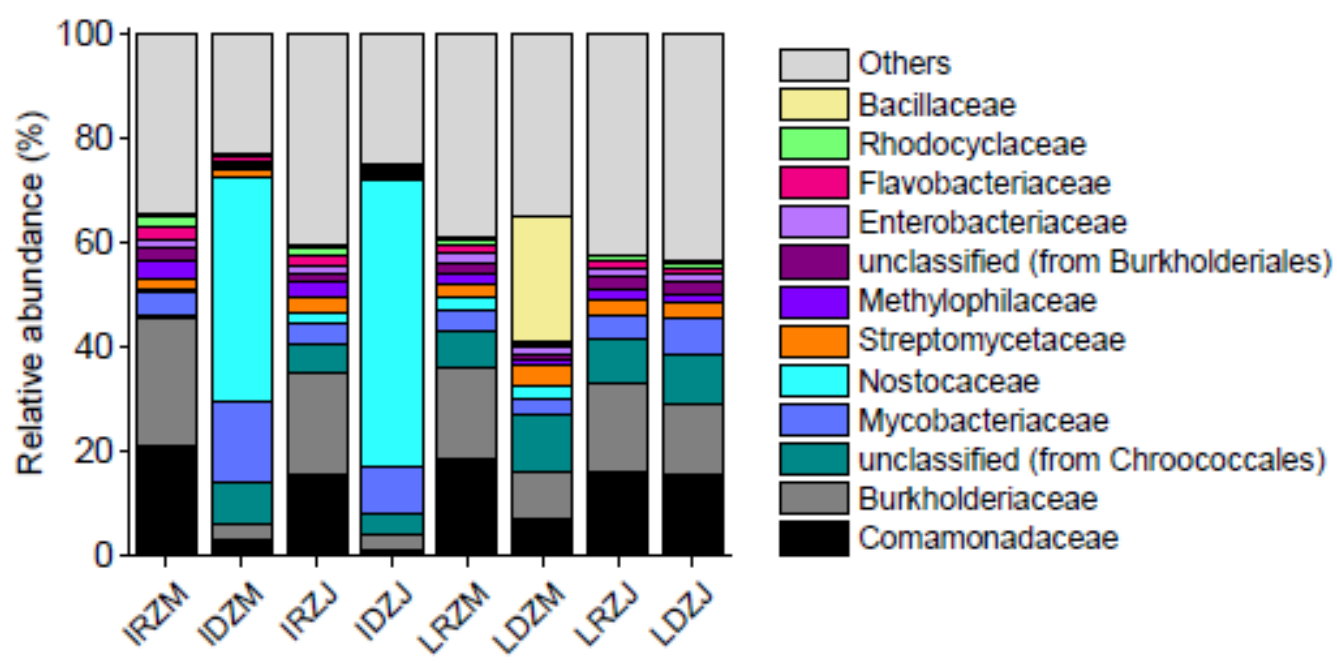

Figure 2-8. Relative abundance (above 1\%) of bacterial families in metagenomes from Itupararanga and Lobo reservoir. Abbreviations means I: Itupararanga reservoir; RZ: River zone; DZ: Dam zone; L: Lobo reservoir.

The db-RDA analysis (Figure 2-9) was performed with environmental variables that had VIF $<2.5$ and with families that had a relative abundance above $5 \%$. The model was significant $(\mathrm{p}=0.043)$ and most of the variation was explained by the first two axes (CAP1 76.8\% and CAP2 18.7\%). The analysis showed two distinct sample groups. The first group (located on the left section of the diagram) was composed by samples from the Lobo reservoir (except LDZM) and from the Itupararanga river zone. This group was associated with high nitrate, PT, and DOC concentrations, and with heterotrophic bacteria belonging to the families Comamonadaceae, Burkholderiaceae, Streptomycetaceae, Methylophilaceae, Enterobacteriaceae, Flavobacteriaceae, and Rhodocyclaceae. In the second group, samples from the Itupararanga dam zone (IDZM and IDZJ) were grouped together and related to the families Nostocaceae and Mycobacteriaceae, with high conductivity. Spearman correlation also showed strong correlation $(r=0.77, \mathrm{p}<0.05)$ between $R$. raciborskii and Mycobacteriaceae abundance. 


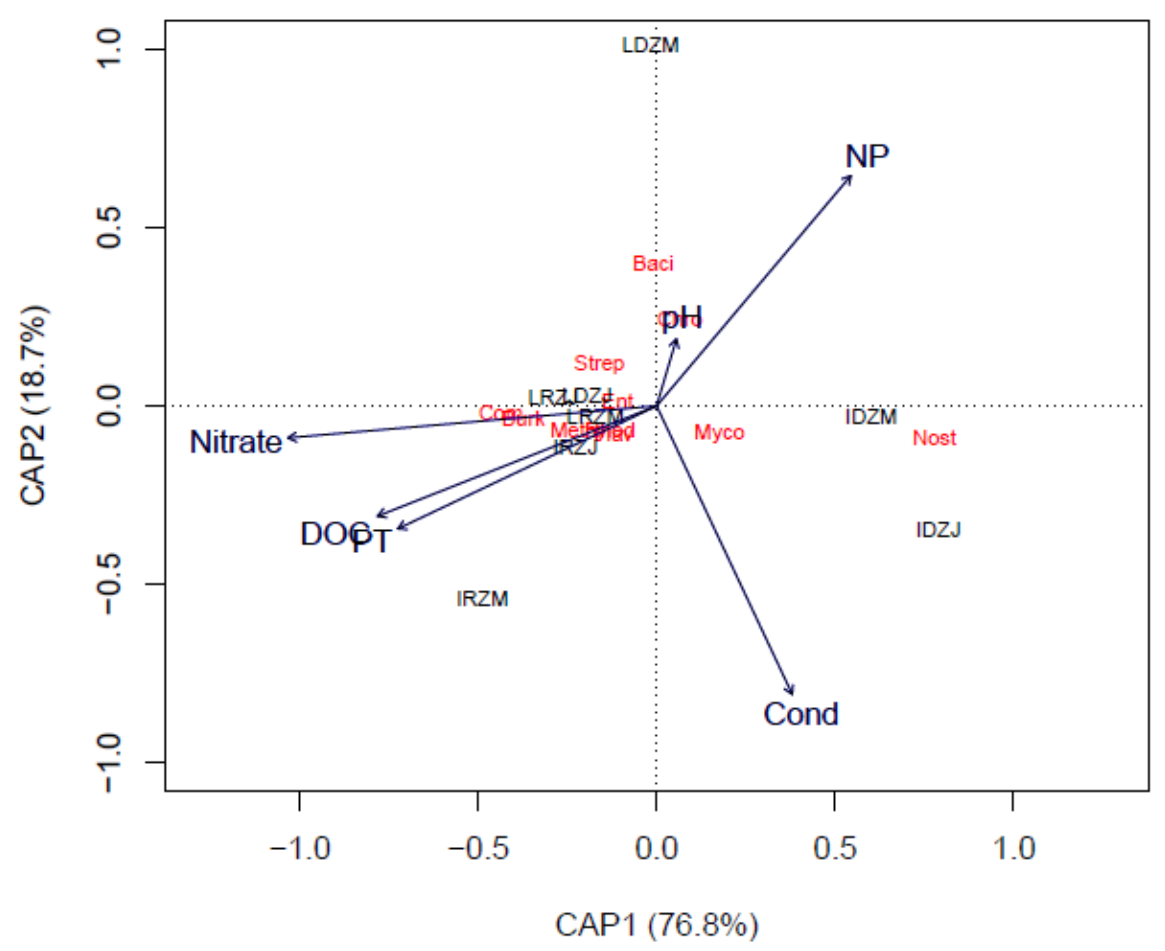

Figure 2-9. Distance-based redundancy analysis (db-RDA) between bacterial community composition at family level (with relative abundance above 1\%) and environmental variables. Abbreviations: I: Itupararanga reservoir; L: Lobo reservoir; DZ: dam zone; RZ: river zone; M: May/2017, J: January/2018; Cond: electric conductivity, DOC: Dissolved organic carbon; NP nitrogen and phosphorus ratio; Com: Comamonadaceae; Burk: Burkholderiaceae; Chro: unclassified derived from Chroococcales; Myco: Mycobacteriaceae; Nost: Nostocaceae; Strep: Streptomycetaceae; Methy: Methylophilaceae; Ent: Enterobacteriaceae; Flav: Flavobacteriaceae; Rhod: Rhodocyclaceae; Baci: Bacillaceae.

\section{Functional profile}

Functional profiles were determined according to the SEED database in 28 subsystems, at level 1 (Figure S2-1). The most abundant subsystems in both reservoirs were Carbohydrates (12,9 - 13.8\%), Protein metabolism (9.5 - 10.7\%) and Amino Acids and Derivatives $(10.1-11.1 \%)$. Genes related to Nitrogen metabolism corresponded to approximately $1 \%$ of the annotated sequences with known function. The functional profiles of the metagenomes between samples sites were compared using STAMP, and we observe significant variations in many functional categories only in Itupararanga reservoir (Figure 2-10). For example, genes related to Nitrogen metabolism and Photosynthesis were more abundant in the dam zone, whereas genes related to aromatic compounds metabolism and related to the Virulence, Disease and Defense category, were 
more abundant in samples from the river zone. Within virulence metabolism, high abundances of antibiotic resistance genes and toxic compounds have been detected in Itupararanga river zone (Figure S2-2).

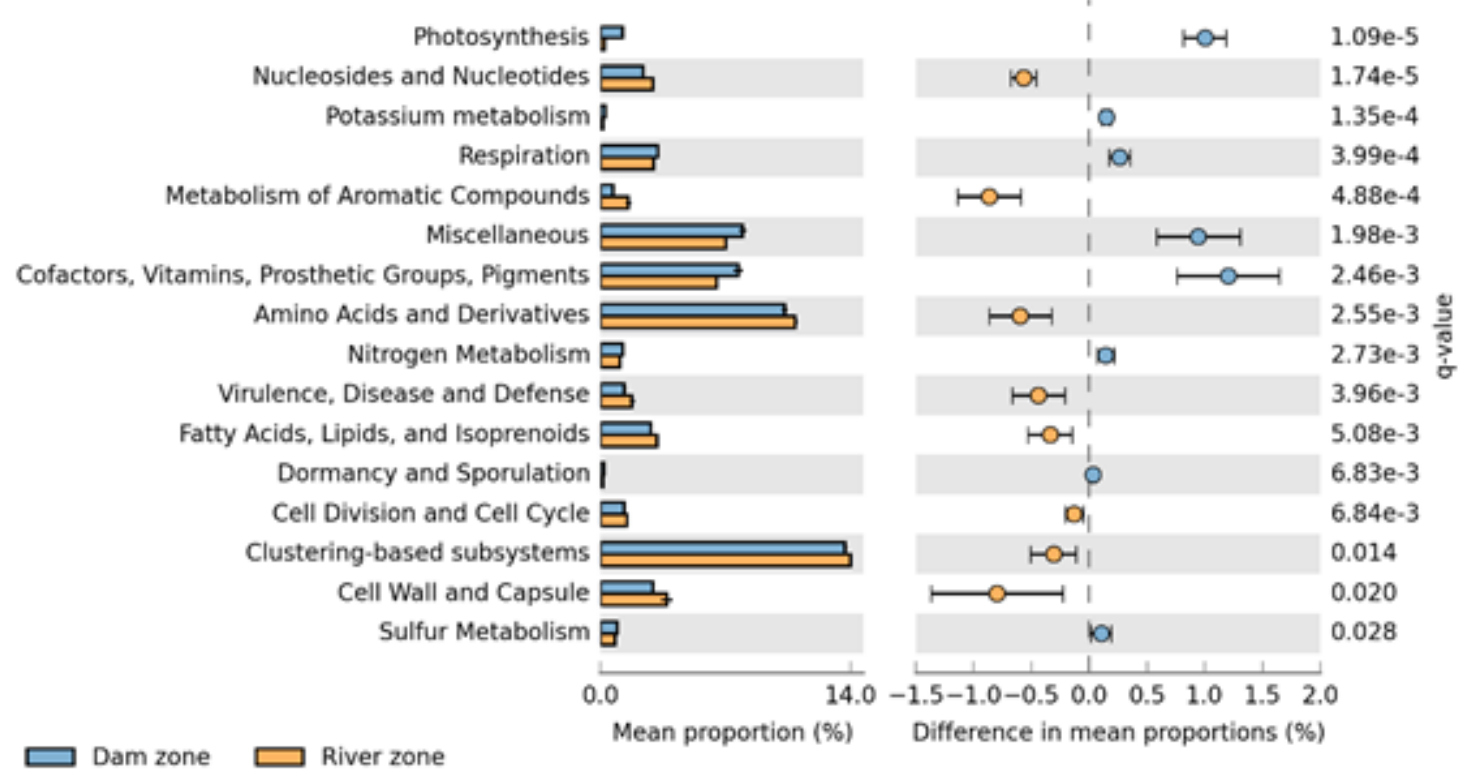

Figure 2-10. SEED subsystems (at level 1) with significant differences in metagenomes from the Itupararanga reservoir. Positive differences between proportions denote gene overrepresentation in the dam zone (blue), whereas negative differences between proportion denote overrepresentation in the river zone (blue).

In the Itupararanga reservoir, no significant difference was observed in the sampling period between May/2017 and January/2018. On the other hand, only a temporal difference was observed in the functional profile from the Lobo reservoir (Figure 2-11).

$\mathrm{Jan} / 2018 \square \mathrm{May} / 2017$

Phages, Prophages, Transposable elements, Plasmids Nucleosides and Nucleotides

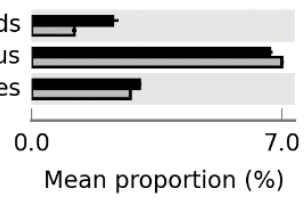

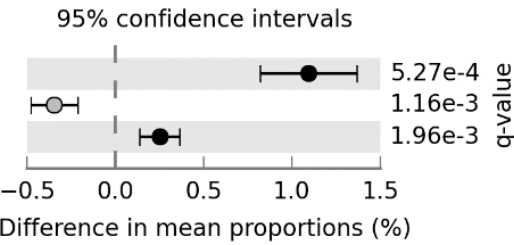

Figure 2-11. SEED subsystems (at level 1) with significant differences in metagenomes from the Lobo reservoir. Positive differences between proportions denote gene overrepresentation in January/2018 (black), whereas negative differences between proportion denote overrepresentation in May/2017 (gray). 
Within Nitrogen metabolism pathways, genes related to $\mathrm{N}$-fixation and nitrate and nitrite ammonification paths were more abundant in the Itupararanga dam zone, while genes related to denitrification and ammonium assimilation were overrepresented in the river zone (Figure 2-12. A). The same metabolic pathways were identified in the Lobo reservoir, but without significant temporal and spatial difference. Furthermore, this ecosystem had low genetic potential for $\mathrm{N}$-fixation (Figure 2-13. B)

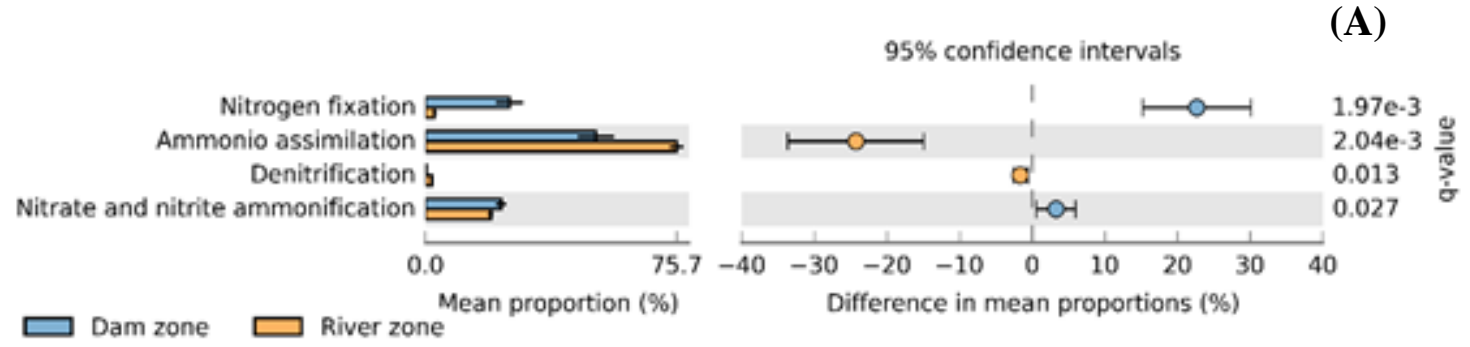

(B)

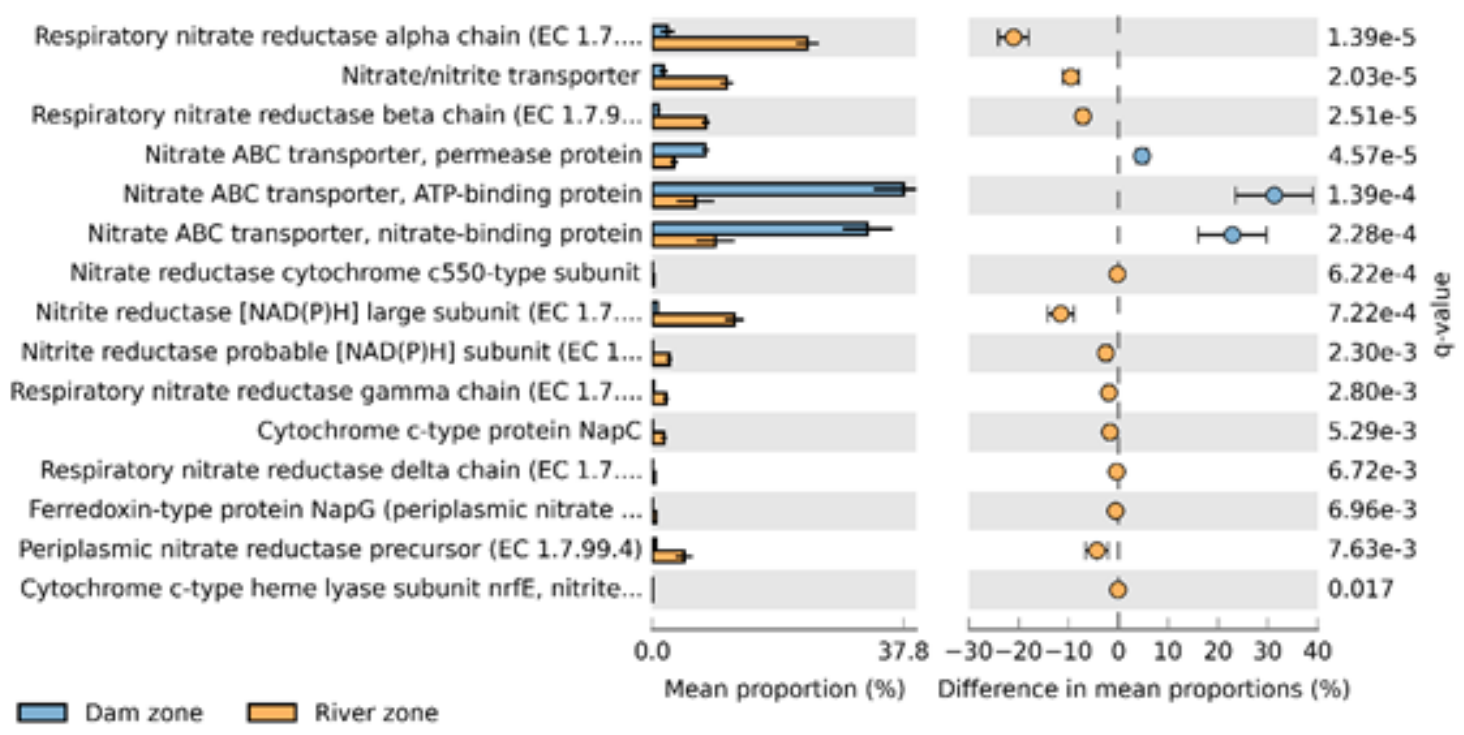

Figure 2-12. Significant differences between functional genes classified according to SEED subsystems in metagenomes from the Itupararanga reservoir. (A) "Genes related to Nitrogen metabolism" category and (B) genes related to "Nitrate and nitrite ammonification" category.

In Itupararanga, most of sequences related to $\mathrm{N}$-fixation were taxonomically affiliated to the Nostocaceae (Figure 2-13.B), but the results also indicated the presence of sequences linked to Rhodocyclaceae and Pseudomonadaceae in the river zone samples in May/2017. Regarding the nitrate and nitrite ammonification paths, the sequences assigned to this metabolism were mostly affiliated to Nostocaceae and Chroococcales (Figure 2-13.C), in samples from Itupararanga (dam zone). To better understand this 
result, we explored the categories related to ammonification were explored within SEED subsystem and we found out a high abundance of functional genes associated with nitrate $\mathrm{ABC}$ transporter system in metagenomes from the Itupararanga dam zone (Figure 212.B).

Both reservoirs showed high genetic potential for ammonium assimilation (Figure 2-13. A) and low potential for denitrification (Figure 2-13. D). In the Lobo reservoir, most of the sequences related to denitrification were affiliated to Burkholderiaceae, while in the Itupararanga river zone, denitrification was related to Burkholderiaceae, and to Comamonadaceae, Rhodocyclaceae, Pseudomonadaceae and Methylococcaceae.

(A)

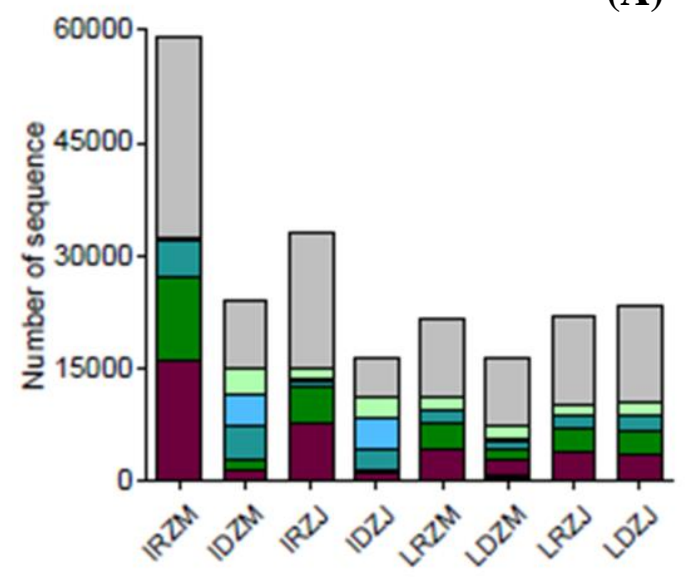

(C)

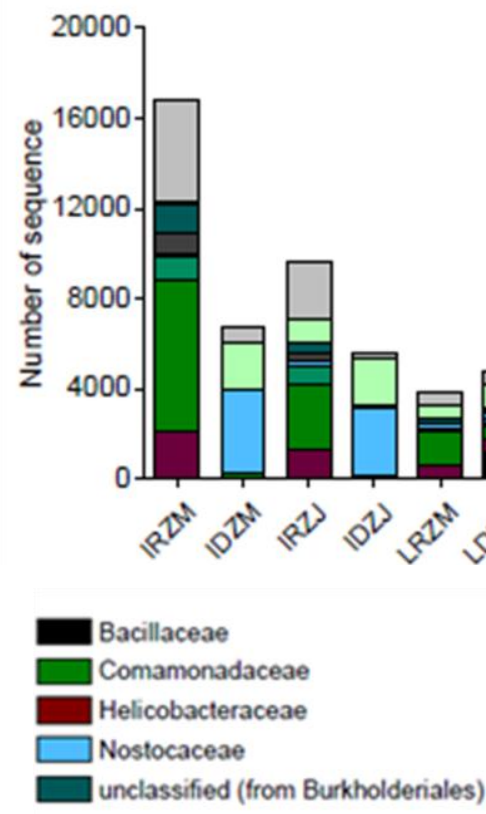

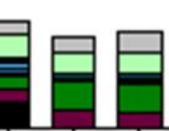
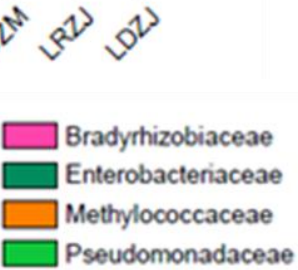

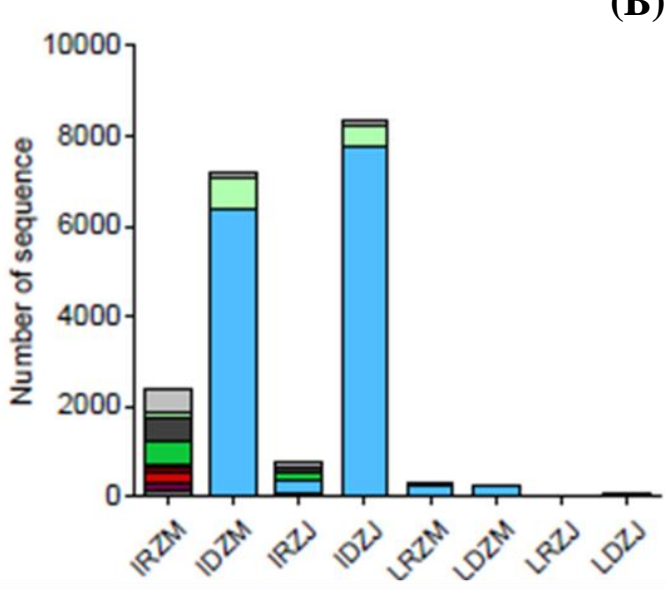

(D)

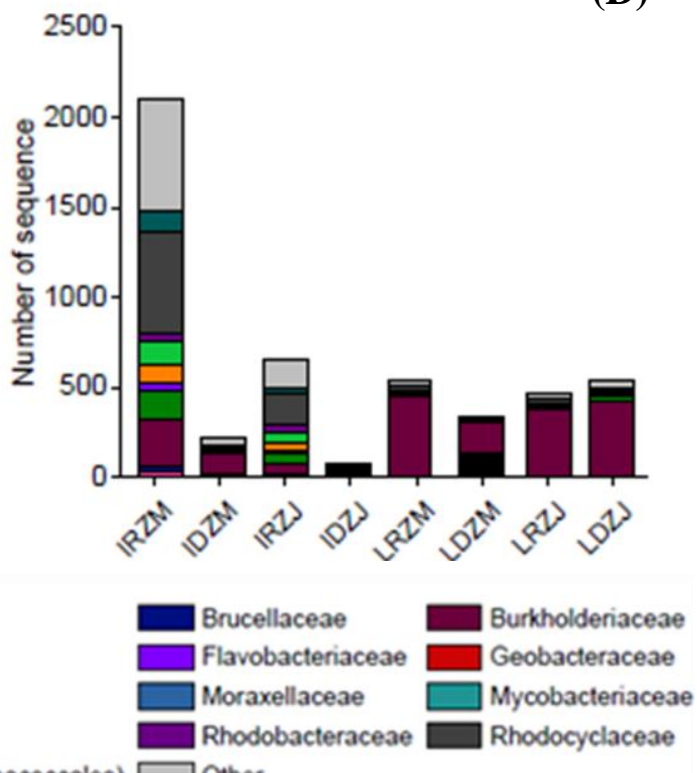

Figure 2-13. Number of sequences of the bacterial families related to Nitrogen metabolism categories according to SEED subsystem and NCBI RefSeq data base. (A) Ammonium Assimilation, (B) Nitrogen fixation, (C) Nitrate and nitrite ammonification and (D) Denitrification. 


\section{Discussion}

This study promoted insights into the composition of bacterioplankton and phytoplankton. We also explored the roles of this microorganisms in nitrogen metabolism from freshwater environments.

Our results showed that phytoplankton was responsible for the majority of $\mathrm{N}$ uptake $(88-99 \%)$, while free living heterotrophic bacteria $(<1.0 \mu \mathrm{m})$ accounted for 1 $14 \%$ of the total $\mathrm{N}$ uptake. The bacterial contribution to total $\mathrm{N}$ uptake tends to be higher in ecosystems with low phytoplankton biomass (e.g Chl $a<2 \mu \mathrm{g} \mathrm{L}^{-1}$ ), accounting for 5195\% and 43-80\% of $\mathrm{NO}_{3}{ }^{-}$and $\mathrm{NH}_{4}{ }^{+}$uptake, respectively (Fouilland et al., 2007). To our knowledge, measures of free-living heterotrophic bacteria uptake in meso-eutrophic subtropical reservoirs were missing and our results suggest that these microorganisms had a low contribution to the total $\mathrm{N}$ uptake $\left(\mathrm{NO}_{3}{ }^{-}\right.$uptake $+\mathrm{NH}_{4}{ }^{+}$uptake) in this type of environment. Despite this, our metagenomic analysis showed high genetic potential for ammonium assimilation within heterotrophic bacterial groups. Similar functional characteristics were reported in lakes (Rathour et al., 2020), aquaculture pond (Deng et al., 2020), soda lakes (Andreote et al., 2018), and streams (Reis et al., 2016).

Understanding $\mathrm{N}$ uptake patterns and their environmental controls is important because this knowledge may promote insights into controlling $\mathrm{N}$ dynamics in ecosystems. In our study, temperature was positively correlated with $\mathrm{NO}_{3}{ }^{-}, \mathrm{NH}_{4}{ }^{+}$, and total $\mathrm{N}$ uptakes rates $\left(\mathrm{NO}_{3}{ }^{-}\right.$uptake+ $\mathrm{NH}_{4}{ }^{+}$uptake), suggesting that the uptake metabolism tends to be higher in warmer seasons, as reported in other studies (Kumar, Sterner and Finlay, 2008; Yu et al., 2018). Due to this trend, we expected to see high $\mathrm{N}$ uptake rates in subtropical reservoirs, which usually has higher water temperature compared to ecosystems located in temperate zones (Lewis, 2000). However, we observed low $\mathrm{N}$ uptake rates in the Itupararanga and Lobo reservoirs, and our results were compatible with temperate environments. For example, in the Tahoe Lake and Walker Lake, $\mathrm{NO}_{3}{ }^{-}$uptake ranged from 37.2 to $114 \mathrm{nmol} \mathrm{N} \mathrm{L}{ }^{-1} \mathrm{~h}^{-1}$ (Romero et al., 2013), while $\mathrm{NH}_{4}^{+}$uptake reached approximately $300 \mathrm{nmolNL}^{-1} \mathrm{~h}^{-1}$ in Kinneret Lake (Berman et al., 1984). A previous study carried out in Itupararanga showed similar results, but it also showed a high variation over two years of sampling, and in some occasions the uptake rates were higher than our results (Cunha et al., 2017).

The patterns of $\mathrm{N}$ uptake in aquatic environments can also be influenced by the composition of phytoplankton (Gobler et al., 2016; Cunha et al., 2017). In our study, cyanobacteria were important components of phytoplankton and bacterioplankton, and 
play a key role in different nitrogen pathways. Cyanobacteria was positively correlated with $\mathrm{NO}_{3}^{-}$uptake rates, and also showed high genetic potential for $\mathrm{N}$-fixation. Microscopic analysis revealed high proportions of Raphidiopsis raciborskii (basionym Cylindrospermopsis raciborskii (Wołoszyńska) Seenayya \& Subba Raju) (Aguilera et al., 2018) in all samples from the Itupararanga dam zone, especially in January/2018. The occurrence and dominance of $R$. raciborskii has been reported not only in the Itupararanga reservoir (Beghelli et al., 2016; Casali et al., 2017), but also in several other ecosystems (Figueredo and Giani, 2009; Sinha et al., 2012; Guedes et al., 2018; Li et al., 2020). A combination of factors may favor the dominance of $R$. raciborskii, including the ability to deal with low and fluctuating $\mathrm{N}$ availability through the $\mathrm{N}$-fixation process (Burford et al., 2016). The reduction of atmospheric nitrogen in ammonium is carried out by microorganisms that have the nitrogenase enzyme, such as R.raciborskii (Sinha et al., 2012). This strategy may promote a competitive advantage over non-fixing cyanobacteria and eukaryotic algae in ecosystems with low availability of dissolved nitrogen (Burford et al., 2018). In our results, the ammonium concentrations were low, and we found high genetic potential for $\mathrm{N}$-fixation linked to Nostocaceae in metagenomes. Here, even though the $\mathrm{N}$-fixation rate was not measured, we suggest that this process may occur at the Itupararanga dam zone, probably associated with $R$.raciborskii.

$\mathrm{N}$-fixation is an energetically expensive process (Burford et al., 2018). Generally, ammonium followed by nitrate are the preferred $\mathrm{N}$ source of cyanobacteria (Spróber et al., 2003; Burford et al., 2006; Burford et al., 2016) and other phytoplankton groups (Glibert et al., 2016; Cunha et al., 2017). In our study, ammonium was the $\mathrm{N}$ form preferred by phytoplankton in many occasions, however nitrate was also an important $\mathrm{N}$ source for the community. Nitrate was the main component of DIN in all samples from Itupararanga and Lobo, and some phytoplankton groups were able to use this $\mathrm{N}$ form efficiently.

Our results showed a positive correlation between $\mathrm{NO}_{3}{ }^{+}$uptake and biovolumes of cyanobacteria and dinoflagellates. In the samples from the Itupararanga dam zone, we found a high abundance of genes related to nitrate transport proteins, which were probably linked to cyanobacteria, since many sequences derived from nitrate/nitrite ammonification category were affiliated to Nostocaceae and Chroococcales. Previous studies reported that when ammonium is not available, cyanobacteria can take up nitrate through a multicomponent $\mathrm{ABC}$ transporter (ATP-binding) system located in the cytoplasmic membrane (Nagore et al., 2006; Maeda et al., 2015). We suggest that the 
high genetic potential of cyanobacteria to drive nitrate uptake and N-fixation may ensure a flexibility on strategies to take up different $\mathrm{N}$ sources from water, potentially promoting the success of cyanobacteria in ecosystems (Chislock, Sharp and Wilson, 2014; Willis, Chuang and Burford, 2016).

Other phytoplankton groups, dinoflagellates and diatoms, seem to be favored from $\mathrm{NO}_{3}{ }^{+}$uptake even when ammonium is available (Glibert et al., 2016; Cunha et al., 2017). In our results, there was no correlation between $\mathrm{NO}_{3}{ }^{-}$uptake and diatoms, but we found a positive correlation for dinoflagellates. The highest $\mathrm{NO}_{3}{ }^{+}$uptake rate was observed in October/2017, when bloom formation of Ceratium furcoides occurred in the river zone from Itupararanga. Previous studies have registered C. furcoides bloom formation linked with warmer seasons (spring-summer), water turbulence, high conductivity, and secondarily, with nutrient availability (Matsumura-Tundisi et al., 2010; Silva et al., 2012; Cavalcante et al., 2016; Crossetti et al., 2019). In this study, db-RDA analysis showed a positive relationship between C.furcoides and conductivity. However, this is the first record of Ceratium bloom formation in Itupararanga, so further studies are needed to better understand the dynamics of this species in the reservoir.

In the river zone from both reservoirs we observed high concentrations of nitrate, PT, and DOC, which were positively related to families belonging to Proteobacteria. Within Proteobacteria, Burkholderiaceae and Comamonadaceae were the most abundant families in almost all sample sites (except in the Itupararanga dam zone). Some members of Comamonadaceae may be able to perform denitrification processes (Heylen et al., 2006; Huang et al., 2011). However, the genetic potential for denitrification was very low in our metagenomes and few sequences were affiliated with Comamonadaceae. In contrast, most of the sequences related to denitrification were affiliated to Burkholderiaceae in the samples from the Lobo reservoir. According to previous studies, members of this family may be suitable not only for denitrification (Huang et al., 2011; Atalo et al., 2019; Deng et al., 2020), but also for nitrification (Peura et al., 2015). However, we did not detect genes involved with nitrification in our metagenomic data. Similar results were observed in streams (Meneghine et al., 2017) and lakes (LlorensMarès et al., 2015).

Denitrification processes involve transforming $\mathrm{N}$ compounds $\left(\mathrm{NO}_{3}{ }^{-} \rightarrow \mathrm{NO}_{2}{ }^{-}\right.$ $\rightarrow \mathrm{NO} \rightarrow \mathrm{N}_{2} \mathrm{O}$ ) in $\mathrm{N}_{2}$ (Zumft, 1997), while ammonium is converted to nitrite and nitrate $\left(\mathrm{NH} 4+\rightarrow \mathrm{NO}_{2}^{-} \rightarrow \mathrm{NO}_{3}^{-}\right.$) in the nitrification (Dodds and Whiles, 2010). Both processes are related to nitrogen removal or control, so they are especially important for studies of 
bioremediation in polluted environments (Yan et al., 2011; Ni et al., 2018). Generally, these two pathways are linked to sediment or to low depths of ecosystems (Pauer and Auer, 2000; Tomaszec and Czerwieniec, 2003). This probably explains the deficit of genes related to nitrification and denitrification in our metagenomic data, since our samples were collected on the water surface.

Sediment is an important compartment for nitrogen metabolism in reservoirs, since it can contribute to the release of nutrients into the water column (Hu et al., 2001; Wen et al., 2020). Sediment hosts a high microbial diversity (Reis et al., 2016; Wang et al., 2018; Zhang et al., 2019) and previous studies showed that bacterial communities from sediment and water may have distinct potential functions in the biogeochemical processes of carbon, nitrogen, phosphorus, and sulfur (Ren et al., 2019; Deng et al., 2020). Alarming concentrations of PT, NT and toxic metals were detected in the sediment of Itupararanga and Lobo, mainly in the river zone (Frascareli et al., 2018). In addition, high densities of Bacteria and Archaea were found in the sediment from Itupararanga (Soares et al., 2015), despite that little is known about the composition of these communities in both reservoirs.

Regarding the bacterial community from the water column, our metagenomic results showed positive relationships between the heterotrophic families with high concentrations of nitrate, PT, and DOC. The relationship between these abiotic factors and the bacterial community has been widely explored, especially in polluted environments (Reza et al., 2018; Breton-Deval et al., 2019; Cui et al., 2019; Yang et al., 2019). A wide variety of species linked to these bacterial families can be pathogenic or resistant to antibiotics, representing health risks (Cai and Zhang, 2013; Mohiuddin et al., 2017; Gao et al., 2019). It has been reported that microbial dynamics have been altered due to the release of sewage into the water. In addition, the presence of antibiotic resistance and pathogenicity genes may indicate the contamination of environments (Tang et al., 2016; Cui et al., 2019; Mansfeldt et al., 2019). Through functional metagenomic analyses it is possible to access the metabolism of these indicator genes within the "Virulence, Disease and Defense" category, using the SEED database (Meneghine et al., 2017). In our results, both reservoirs showed genetic potential for this harmful metabolism, especially in the river zone from Itupararanga, where this metabolism was overrepresented with $88 \%$ of the genes related to the antibiotic resistance and toxic compounds (Figure S2-2). For this reason, our results agree with previous studies which indicated that Itupararanga and Lobo have been receiving domestic 
effluents, probably from the rivers that inflow into the upstream (Rivera et al., 2007; Frascareli et al., 2018; Simonetti et al., 2019).

We also found a high proportion of Bacilliaceae ( $24 \%$ of the relative abundance - May/2017) in the dam zone from Lobo. Members of this family can be pathogenic and have potential for microcystin degradation ( $\mathrm{Li}$ et al 2017). This cyanotoxin can be produced by genera belonging to the cyanobacterial order Chroococcales, including Microcystis and Aphanocapsa (Jakubowska and Szeląg-Wasielewska, 2015; Mariani et al., 2015, Magalhães et al., 2019). A previous study reported positive correlations between Chroococcales members and microcystin degrading bacteria, mainly belonging to the families Sphingomonadaceae and Xanthomonadaceae (Lezcano et al., 2017). Despite that, the order Chroococcales was not associated with heterotrophic bacterial families in this study.

In contrast, Nostocaceae and Mycobacteriaceae were positively correlated. In our study Nostocaceae was represented predominantly by $R$. raciborskii in Itupararanga, and correlation analyses showed strong relationship between $R$. raciborskii and Mycobacteriaceae abundance. However, little is known about associations between heterotrophic bacteria and $R$. raciborskii. Positive correlations between $R$. raciborskii and the genera Gemmatimonas (Gemmatimonadetes) and Roseococcus (Proteobacteria) were observed in the Funil reservoir (Guedes et al., 2018). In addition, the same authors also reported a high correlation between $R$. raciborskii and order Actinomycetales, which Mycobacteriaceae belongs. Nevertheless, the functional relationship between this groups still unclear (Guedes et al., 2018). Therefore, we recommend laboratory and field studies to investigate associations between $R$. raciborskii, Mycobacteriaceae and other members of the order Actinomycetales.

\section{Conclusion}

We conclude that cyanobacteria play a key role in the composition of microbial communities and in nitrogen metabolism. These microorganisms showed high genetic potential to drive $\mathrm{N}$-fixation and $\mathrm{NO}_{3}{ }^{-}$uptake, which may allow different strategies to take up nitrogen in environments with low ammonium availability. Heterotrophic bacteria showed functional potential to drive different $\mathrm{N}$ paths. However, our results supported the hypothesis that phytoplankton are the main contributors to $\mathrm{N}$ uptake. The metagenomic results contributed to the knowledge regarding taxonomic and functional microbial profiles and they can be used to explore potential pollutant indicators in 
environments. The integrated analysis between bacterioplankton and phytoplankton is necessary and recommended for a better understanding of the aquatic microbial metabolic dynamics.

\section{References}

Aalto, S. L., Saarenheimo, J., Arvola, L., Tiirola, M., Huotari, J., Rissanen, A. J. (2019). Denitrifying microbial communities along a boreal stream with varying land-use. Aquatic Sciences, 81(4), 59.

Aguilera, A., Gómez, E. B., Kaštovský, J., Echenique, R. O., Salerno, G. L. (2018). The polyphasic analysis of two native Raphidiopsis isolates supports the unification of the genera Raphidiopsis and Cylindrospermopsis (Nostocales, Cyanobacteria). Phycologia, 57(2), 130-146.

Andersen, I. M., Williamson, T. J., González, M. J., Vanni, M. J. (2019). Nitrate, ammonium, and phosphorus drive seasonal nutrient limitation of chlorophytes, cyanobacteria, and diatoms in a hyper-eutrophic reservoir. Limnology and Oceanography.

Andreote, A. P., Dini-Andreote, F., Rigonato, J., Machineski, G. S., Souza, B. C., Barbiero, L., Rezende-Filho, A.T., Fiore, M. F. (2018). Contrasting the genetic patterns of microbial communities in soda lakes with and without cyanobacterial bloom. Frontiers in microbiology, 9, 244.

Andrews S. FastQC: A quality control tool for high throughput sequence data [Internet]. http://www.bioinformatics.babraham.ac.uk/projects/fastqc/

APHA - American Public Health Association. Standard methods for the examination of water and wastewater. 25th ed. Washington, DC: American Public Health Association, 2005

Barros, M. U., Wilson, A. E., Leitão, J. I., Pereira, S. P., Buley, R. P., Fernandez-Figueroa, E. G., Capelo-Neto, J. (2019). Environmental factors associated with toxic cyanobacterial blooms across 20 drinking water reservoirs in a semi-arid region of Brazil. Harmful algae, 86, 128-137.

Beghelli, F. G., Frascareli, D., Pompêo, M. L. M., Moschini-Carlos, V. (2016) Trophic State Evolution over 15 Years in a Tropical Reservoir with Low Nitrogen Concentrations and Cyanobacteria Predominance. Water, Air, and Soil Pollution, 227, 1-15.

Benjamini, Y., Hochberg, Y. (1995). Controlling the false discovery rate: a practical and powerful approach to multiple testing. Journal of the Royal statistical society: series B (Methodological), 57(1), 289-300.

Berman, T., Sherr, B. F., Sherr, E., Wynne, D., McCarthy, J. J. (1984). The characteristics of ammonium and nitrate uptake by phytoplankton in Lake Kinneret 1. Limnology and Oceanography, 29(2), 287-297.

Bluman, A.G. (2007). Elementary statistics: A step by step approach (6th edition), McGraw Hill Higher Education, New York, New York.

Breton-Deval, L., Sanchez-Flores, A., Juárez, K., Vera-Estrella, R. (2019). Integrative study of microbial community dynamics and water quality along The Apatlaco River. Environmental Pollution, 255, 113158. 
Burford, M. A., McNeale, K. L., Mckenzie-Smith, F. J. (2006). The role of nitrogen in promoting the toxic cyanophyte Cylindrospermopsis raciborskii in a subtropical water reservoir. Freshwater Biology, 51(11), 2143-2153.

Burford, M. A., Beardall, J., Willis, A., Orr, P. T., Magalhaes, V. F., Rangel, L. M., Azevedo, S. M. F. O. E., Neilan, B. A. (2016). Understanding the winning strategies used by the bloomforming cyanobacterium Cylindrospermopsis raciborskii. Harmful Algae, 54, 44-53.

Burford, M. A., Willis, A., Chuang, A., Man, X., Orr, P. T. (2018). Recent insights into physiological responses to nutrients by the cylindrospermopsin producing cyanobacterium, Cylindrospermopsis raciborskii. Journal of Oceanology and Limnology, 36(4), 1032-1039.

Bradley, P. B., Sanderson, M. P., Frischer, M. E., Brofft, J., Booth, M. G., Kerkhof, L. J., Bronk, D. A. (2010). Inorganic and organic nitrogen uptake by phytoplankton and heterotrophic bacteria in the stratified Mid-Atlantic Bight. Estuarine, Coastal and Shelf Science, 88(4), 429-441.

Cai, L., Zhang, T. (2013). Detecting human bacterial pathogens in wastewater treatment plants by a high-throughput shotgun sequencing technique. Environmental science \& technology, 47(10), 5433-5441.

Cai, M., Wilkins, D., Chen, J., Ng, S. K., Lu, H., Jia, Y., Lee, P. K. (2016). Metagenomic reconstruction of key anaerobic digestion pathways in municipal sludge and industrial wastewater biogas-producing systems. Frontiers in microbiology, 7, 778.

Casali, S. P., Dos Santos, A. C. A., de Falco, P. B., Calijuri, M. C. (2017). Influence of environmental variables on saxitoxin yields by Cylindrospermopsis raciborskii in a mesotrophic subtropical reservoir. Journal of water and health, 15(4), 509-518.

Cavalcante, K. P., de Souza Cardoso, L., Sussella, R., Becker, V. (2016). Towards a comprehension of Ceratium (Dinophyceae) invasion in Brazilian freshwaters: autecology of C. furcoides in subtropical reservoirs. Hydrobiologia, 771(1), 265-280.

Childers, D. L., J. Corman, M. Edwards, and J. J. Elser. 2011. Sustainability challenges of phosphorus and food: Solutions from closing the human phosphorus cycle. Bio-Science 61: 117124

Chislock, M. F., Sharp, K. L., Wilson, A. E. (2014). Cylindrospermopsis raciborskii dominates under very low and high nitrogen-to-phosphorus ratios. Water Research, 49, 207-214.

Chopyk, J., Nasko, D. J., Allard, S., Callahan, M. T., Bui, A., Ferelli, A. M. C., , Suhana Chattopadhyay, S., Mongodin E. F., Pop, M., Micallef, S. A., Sapkota, A. R. (2020). Metagenomic analysis of bacterial and viral assemblages from a freshwater creek and irrigated field reveals temporal and spatial dynamics. Science of The Total Environment, 706, 135395.

Cotner, J. B., Biddanda, B. A. (2002). Small players, large role: microbial influence on biogeochemical processes in pelagic aquatic ecosystems. Ecosystems, 5(2), 105-121.

Crossetti, L. O., de Campos Bicudo, D., Bini, L. M., Dala-Corte, R. B., Ferragut, C., Bicudo, C. E. M (2019). Phytoplankton species interactions and invasion by Ceratium furcoides are influenced by extreme drought and water-hyacinth removal in a shallow tropical reservoir. Hydrobiologia, 831(1), 71-85.

Cui, Q., Huang, Y., Wang, H., Fang, T. (2019). Diversity and abundance of bacterial pathogens in urban rivers impacted by domestic sewage. Environmental pollution, 249, 24-35. 
Cunha, D. G. F., Calijuri, M. C., Lamparelli, M.C. (2013). A trophic state index for tropical/subtropical reservoirs (TSI tsr). Ecological Engineering, 60, 126-134.

Cunha, D. G. F., Lima, V. F. M., Néri, A. M, Marafão, G. A., Miwa, A. C. P., Calijuri, M. C, Bendassoli, J.A., Tromboni, F., Maranger, R. (2017). Uptake rates of ammonium and nitrate by phytoplankton communities in two eutrophic tropical reservoirs. International Review of Hydrobiology, 102(5-6), 125-134.

Decol, L. T., Casarin, L. S., Hessel, C. T., Batista, A. C. F., Allende, A., Tondo, E. C. (2017). Microbial quality of irrigation water used in leafy green production in Southern Brazil and its relationship with produce safety. Food microbiology, 65, 105-113.

Delmont, T. O., Quince, C., Shaiber, A., Esen, Ö. C., Lee, S. T., Rappé, M. S., MacLellan, S. L., Lücker, S., Eren, A. M. (2018). Nitrogen-fixing populations of Planctomycetes and Proteobacteria are abundant in surface ocean metagenomes. Nature Microbiology, 3(7), 804-813.

Deng, M., Hou, J., Song, K., Chen, J., Gou, J., Li, D., He, X. (2020). Community metagenomic assembly reveals microbes that contribute to the vertical stratification of nitrogen cycling in an aquaculture pond. Aquaculture, 520, 734911.

Dodds, W., Whiles, M., Dodds, W. K., Whiles, M. R. (2010). Nitrogen, sulfur, phosphorus, and other nutrients. In: Freshwater Ecology: concepts and environmental applications of limnology Elsevier Inc.: Amsterdam, The Netherlands, p. 345-373.

Donald, D. B., Bogard, M. J., Finlay, K., Leavitt, P. R. (2011). Comparative effects of urea, ammonium, and nitrate on phytoplankton abundance, community composition, and toxicity in hypereutrophic freshwaters. Limnology and Oceanography, 56(6), 2161-2175.

Dugdale, R.C., F.P. Wilkerson. 1986. The use of ${ }^{15} \mathrm{~N}$ to measure nitrogen uptake in eutrophic oceans; experimental considerations. Limnology and Oceanography 31, 673-689.

Fasching, C., Akotoye, C., Bižić, M., Fonvielle, J., Ionescu, D., Mathavarajah, S., Zoccarato,L., Walsh, D. A., Grossart, H. P., Xenopoulos, M. A. (2020). Linking stream microbial community functional genes to dissolved organic matter and inorganic nutrients. Limnology and Oceanography, 65, S71-S87.

Figueredo, C. C., Giani, A. (2009). Phytoplankton community in the tropical lake of Lagoa Santa (Brazil): conditions favoring a persistent bloom of Cylindrospermopsis raciborskii. Limnologica, 39(4), 264-272.

Fonseca, B. M., Ferragut, C., Tucci, A., Crossetti, L. O., Ferrari, F., Bicudo, D. D. C., Sant'Anna, C. L., Bicudo, C. E. D. M. (2014). Biovolume de cianobactérias e algas de reservatórios tropicais do Brasil com diferentes estados tróficos. Hoehnea, 41, 9-30.

Fouilland, E., Gosselin, M., Rivkin, R. B., Vasseur, C., Mostajir, B. (2007). Nitrogen uptake by heterotrophic bacteria and phytoplankton in Arctic surface waters. Journal of Plankton Research, 29(4), 369-376.

Frascareli, D., Cardoso-Silva, S., Mizael, J. D. O. S. S., Rosa, A. H., Pompêo, M. L. M., LópezDoval, J. C., Moschini-Carlos, V. (2018). Spatial distribution, bioavailability, and toxicity of metals in surface sediments of tropical reservoirs, Brazil. Environmental monitoring and assessment, 190(4), 199. 
Gao, Y., Wang, C., Zhang, W., Di, P., Yi, N., Chen, C. (2017). Vertical and horizontal assemblage patterns of bacterial communities in a eutrophic river receiving domestic wastewater in southeast China. Environmental Pollution, 230, 469-478.

Glibert, P. M., Wilkerson, F. P., Dugdale, R. C., Raven, J. A., Dupont, C. L., Leavitt, P. R., Parker, A. E., Burkholder, J. M., Kana, T. M. (2016). Pluses and minuses of ammonium and nitrate uptake and assimilation by phytoplankton and implications for productivity and community composition, with emphasis on nitrogen-enriched conditions. Limnology and Oceanography, 61(1), 165-197.

Grossart, H. P., Massana, R., McMahon, K. D., Walsh, D. A. (2020). Linking metagenomics to aquatic microbial ecology and biogeochemical cycles. Limnology and Oceanography, 65, S2S20.

Gobler, C. J., Burkholder, J. M., Davis, T. W., Harke, M. J., Johengen, T., Stow, C. A., Van de Waal, D. B. (2016). The dual role of nitrogen supply in controlling the growth and toxicity of cyanobacterial blooms. Harmful Algae, 54, 87-97.

Guedes, I. A., Rachid, C. T., Rangel, L. M., Silva, L. H., Bisch, P. M., Azevedo, S. M., Pacheco, A. B. (2018). Close link between harmful cyanobacterial dominance and associated bacterioplankton in a tropical eutrophic reservoir. Frontiers in microbiology, 9, 424.

Heylen, K., Gevers, D., Vanparys, B., Wittebolle, L., Geets, J., Boon, N., De Vos, P. (2006). The incidence of nirS and nirK and their genetic heterogeneity in cultivated denitrifiers. Environmental microbiology, 8(11), 2012-2021.

Hillebrand, H., Dürselen, C. D., Kirschtel, D., Pollingher, U., Zohary, T. (1999). Biovolume calculation for pelagic and benthic microalgae. Journal of phycology, 35(2), 403-424.

Hogeboom, R. J., Knook, L., Hoekstra, A. Y. (2018). The blue water footprint of the world's artificial reservoirs for hydroelectricity, irrigation, residential and industrial water supply, flood protection, fishing and recreation. Advances in water resources, 113, 285-294.

Hu, W. F., Lo, W., Chua, H., Sin, S. N., Yu, P. H. F. (2001). Nutrient release and sediment oxygen demand in a eutrophic land-locked embayment in Hong Kong. Environment International, 26(56), 369-375.

Huang, S., Chen, C., Wu, Q., Zhang, R., Yang, X. (2011). Distribution of typical denitrifying functional genes and diversity of the nirS-encoding bacterial community related to environmental characteristics of river sediments. Biogeosciences Discussions, 8(3).

Jakubowska, N., Szeląg-Wasielewska, E. (2015). Toxic picoplanktonic cyanobacteria. Marine drugs, 13(3), 1497-1518.

Kirchman, D. L., Wheeler, P. A. (1998). Uptake of ammonium and nitrate by heterotrophic bacteria and phytoplankton in the sub-Arctic Pacific. Deep Sea Research Part I: Oceanographic Research Papers, 45(2-3), 347-365.

Kleinteich, J., Hilt, S., Hoppe, A., Zarfl, C. (2020). Structural changes of the microplankton community following a pulse of inorganic nitrogen in a eutrophic river. Limnology and Oceanography, 65, S264-S276.

Koroleff, F. (1976). Determination of nutrients: Ammonia. In Methods of seawater analysis. Verlag Chemie, Weinheim: 126-133. 
Kumar, S., Sterner, R. W., Finlay, J. C. (2008). Nitrogen and carbon uptake dynamics in Lake Superior. Journal of Geophysical Research: Biogeosciences, 113(G4).

Lezcano, M. Á., Velázquez, D., Quesada, A., \& El-Shehawy, R. (2017). Diversity and temporal shifts of the bacterial community associated with a toxic cyanobacterial bloom: An interplay between microcystin producers and degraders. Water research, 125, 52-61.

Legendre, P.; L. Legendre, 1998. Numerical Ecology. Elsevier Science, Amsterdam.

Lewis Jr, W. M. (2000). Basis for the protection and management of tropical lakes. Lakes \& Reservoirs: Research \& Management, 5(1), 35-48.

Lewis Jr, W. M. (2010). Biogeochemistry of tropical lakes. Internationale Vereinigung für theoretische und angewandte Limnologie: Verhandlungen, 30(10), 1595-1603.

Li, J., Li, R., Li, J. (2017). Current research scenario for microcystins biodegradation-a review on fundamental knowledge, application prospects and challenges. Science of The Total Environment, 595, 615-632.

Li, X., Huo, S., Zhang, J., Xiao, Z., Xi, B., Li, R. (2020). Factors related to aggravated Cylindrospermopsis (Cyanobacteria) bloom following sediment dredging in an eutrophic shallow lake. Environmental Science and Ecotechnology, 100014.

Llorens-Marès, T., Yooseph, S., Goll, J., Hoffman, J., Vila-Costa, M., Borrego, C. M., Dupont, C. L., Casamayor, E. O. (2015). Connecting biodiversity and potential functional role in modern euxinic environments by microbial metagenomics. The ISME journal, 9(7), 1648-1661.

Llorens-Marès, T., Catalan, J., Casamayor, E. O. (2020). Taxonomy and functional interactions in upper and bottom waters of an oligotrophic high-mountain deep lake (Redon, Pyrenees) unveiled by microbial metagenomics. Science of The Total Environment, 707, 135929.

Maeda, S. I., Murakami, A., Ito, H., Tanaka, A., Omata, T. (2015). Functional characterization of the FNT family nitrite transporter of marine picocyanobacteria. Life, 5(1), 432-446.

Magalhães, A. A., Luz, L. D., Aguiar T. R J. (2019). Environmental factors driving the dominance of the harmful bloom-forming cyanobacteria Microcystis and Aphanocapsa in a tropical water supply reservoir. Water Environment Research, 91(11), 1466-1478.

Mariani, M. A., Padedda, B. M., Kaštovský, J., Buscarinu, P., Sechi, N., Virdis, T., Lugliè, A. (2015). Effects of trophic status on microcystin production and the dominance of cyanobacteria in the phytoplankton assemblage of Mediterranean reservoirs. Scientific reports, 5, 17964.

Mansano, A. S., Moreira, R. A., Dornfeld, H. C., Freitas, E. C., Vieira, E. M., Sarmento, H., Rocha, O., Seleghim, M. H. (2017). Effects of diuron and carbofuran and their mixtures on the microalgae Raphidocelis subcapitata. Ecotoxicology and environmental safety, 142, 312-321.

Mansfeldt, C., Deiner, K., Mächler, E., Fenner, K., Eggen, R. I., Stamm, C., Schönenberger, U., Walser, J.C., Altermatt, F. (2020). Microbial community shifts in streams receiving treated wastewater effluent. Science of the Total Environment, 709, 135727.

Matsumura-Tundisi, T., Tundisi, J. G., Luzia, A. P., Degani, R. M. (2010). Occurrence of Ceratium furcoides (Levander) Langhans 1925 bloom at the Billings Reservoir, São Paulo State, Brazil. Brazilian Journal of Biology, 70(3), 825-829. 
Meneghine, A. K., Nielsen, S., Varani, A. M., Thomas, T., Alves, L. M. C. (2017). Metagenomic analysis of soil and freshwater from zoo agricultural area with organic fertilization. PloS one, 12(12).

Meyer, F., Paarmann, D., D'Souza, M., Olson, R., Glass, E. M., Kubal, M., Paczian, T., Rodriguez, A., Stevens, R., Wilke, A., Wilkening, J., Wilkening, J. (2008). The metagenomics RAST server-a public resource for the automatic phylogenetic and functional analysis of metagenomes. BMC bioinformatics, 9(1), 386.

Mohiuddin, M. M., Salama, Y., Schellhorn, H. E., Golding, G. B. (2017). Shotgun metagenomic sequencing reveals freshwater beach sands as reservoir of bacterial pathogens. Water research, 115, 360-369.

Nusch, E. A. (1980). Comparison of different methods for chlorophyll and pheopigment determination. Archiv für Hydrobiologie, 14, 14-36.

Nagore, D., Sanz, B., Soria, J., Llarena, M., Llama, M. J., Calvete, J. J., Serra, J. L. (2006). The nitrate/nitrite $\mathrm{ABC}$ transporter of Phormidium laminosum: phosphorylation state of NrtA is not involved in its substrate binding activity. Biochimica et Biophysica Acta (BBA)-General Subjects, 1760(2), 172-181.

Ni, Z., Wu, X., Li, L., Lv, Z., Zhang, Z., Hao, A., Iseri, Y., Kuba, T., Zhang, X., Wu, W. M., Li, C. (2018). Pollution control and in situ bioremediation for lake aquaculture using an ecological dam. Journal of Cleaner Production, 172, 2256-2265.

Overbeek, R., Begley, T., Butler, R. M., Choudhuri, J. V., Chuang, H. Y., Cohoon, M., et al. (2005). The subsystems approach to genome annotation and its use in the project to annotate 1000 genomes. Nucleic acids research, 33(17), 5691-5702.

Paerl, H. W., Paul, V. J. (2012). Climate change: links to global expansion of harmful cyanobacteria. Water research, 46(5), 1349-1363.

Parks, D. H., Beiko, R. G. (2010). Identifying biologically relevant differences between metagenomic communities. Bioinformatics, 26(6), 715-721.

Pavão, A. C., Santos, A. C. A. D., Bottino, F., Benassi, R. F., Calijuri, M. D. C. (2017). Richness and distribution of aquatic macrophytes in a subtropical reservoir in São Paulo, Brazil. Acta Limnologica Brasiliensia, 29, e10.

Pereira, J. M. A., Petrere-Jr, M., Ribeiro-Filho, R. A. (2008). Angling sport fishing in Lobo-Broa reservoir (Itirapina, SP, Brazil). Brazilian Journal of Biology, 68(4), 721-731.

Pauer, J. J., Auer, M. T. (2000). Nitrification in the water column and sediment of a hypereutrophic lake and adjoining river system. Water Research, 34(4), 1247-1254.

Peura, S., Sinclair, L., Bertilsson, S., Eiler, A. (2015). Metagenomic insights into strategies of aerobic and anaerobic carbon and nitrogen transformation in boreal lakes. Scientific reports, 5(1), $1-6$.

R Development Core Team (2008). R: A language and environment for statistical computing. R Foundation for Statistical Computing, Vienna, Austria. ISBN 3-900051-07-0, URL http://www.R-project.org 
Rathour, R., Gupta, J., Mishra, A., Rajeev, A. C., Dupont, C. L., Thakur, I. S. (2020). A comparative metagenomic study reveals microbial diversity and their role in the biogeochemical cycling of Pangong lake. Science of The Total Environment, 139074.

Reis, M. P., Dias, M. F., Costa, P. S., Ávila, M. P., Leite, L. R., de Araújo, F. M., Salim, A. C. M., Bucciarelli-Rodriguez, M., Oliveira, G., Chartone-Souza, E., Nascimento, A. M. (2016). Metagenomic signatures of a tropical mining-impacted stream reveal complex microbial and metabolic networks. Chemosphere, 161, 266-273.

Ren, Z., Qu, X., Peng, W., Yu, Y., Zhang, M. (2019). Functional properties of bacterial communities in water and sediment of the eutrophic river-lake system of Poyang Lake, China. PeerJ, 7, e7318.

Reza, M. S., Mizusawa, N., Kumano, A., Oikawa, C., Ouchi, D., Kobiyama, A., Yamada, Y., Ikeda, Y., Ikeo, K., Sato, S ...Watanabe, S. (2018). Metagenomic analysis using 16S ribosomal RNA genes of a bacterial community in an urban stream, the Tama River, Tokyo. Fisheries science, 84(3), 563-577.

Rivera, E. C., de Queiroz, J. F., Ferraz, J. M., Ortega, E. (2007). Systems models to evaluate eutrophication in the Broa Reservoir, São Carlos, Brazil. Ecological modelling, 202(3-4), 518526.

Romero, I. C., Klein, N. J., Sanudo-Wilhelmy, S. A., Capone, D. G. (2013). Potential trace metal co-limitation controls on $\mathrm{N} 2$ fixation and NO3-uptake in lakes with varying trophic status. Frontiers in microbiology, 4, 54.

Roumpeka, D. D., Wallace, R. J., Escalettes, F., Fotheringham, I., Watson, M. (2017). A review of bioinformatics tools for bio-prospecting from metagenomic sequence data. Frontiers in genetics, 8, 23.

Sarmento, H., Unrein, F., Isumbisho, M., Stenuite, S., Gasol, J. M., Descy, J. P. (2008) Abundance and distribution of picoplankton in tropical, oligotrophic Lake Kivu, eastern Africa. Freshwater Biology, 53, 756-771

Segovia, B. T., Meira, B. R., Lansac-Toha, F. M., Amadeo, F. E., Unrein, F., Velho, L. F. M., Sarmento, H. (2018) Growth and cytometric diversity of bacterial assemblages under different top-down control regimes by using a size-fractionation approach. Journal of Plankton Research, 40, 129-141.

Sharpton, T. J. (2014). An introduction to the analysis of shotgun metagenomic data. Frontiers in plant science, 5, 209.

Silva, L. C., Leone, I. C., Santos-Wisniewski, M. J., Peret, A. C., Rocha, O. (2012) Invasion of the dinoflagellate Ceratium furcoides (Levander) Langhans 1925 at tropical reservoir and its relation to environmental variables. Biota Neotropica, 12(2), 93-100.

Silva, L. H., Huszar, V. L., Marinho, M. M., Rangel, L. M., Brasil, J., Domingues, C. D., Roland, F. (2014). Drivers of phytoplankton, bacterioplankton, and zooplankton carbon biomass in tropical hydroelectric reservoirs. Limnologica, 48, 1-10.

Simonetti, V. C., Frascareli, D., Gontijo, E. S., Melo, D. S., Friese, K., Silva, D. C., Rosa, A. H. (2019). Water quality indices as a tool for evaluating water quality and effects of land use in a tropical catchment. International Journal of River Basin Management, 1-12. 
Sinha, R., Pearson, L. A., Davis, T. W., Burford, M. A., Orr, P. T., Neilan, B. A. (2012). Increased incidence of Cylindrospermopsis raciborskii in temperate zones-is climate change responsible?. Water research, 46(5), 1408-1419.

Sprőber, P., Shafik, H. M., Présing, M., Kovács, A. W., Herodek, S. (2003). Nitrogen uptake and fixation in the cyanobacterium Cylindrospermopsis raciborskii under different nitrogen conditions. Hydrobiologia, 506(1-3), 169-174.

Soares, L. A., Santos, A. C. A. D., Duarte, I. C. S., Romagnoli, E. M., Calijuri, M. D. C. (2015). Distribution of Archaeal and Bacterial communities in a subtropical reservoir. Acta Limnologica Brasiliensia, 27(4), 411-420.

Sun, J., Liu, D. (2003). Geometric models for calculating cell biovolume and surface area for phytoplankton. Journal of plankton research, 25(11), 1331-1346.

Tang, J., Bu, Y., Zhang, X. X., Huang, K., He, X., Ye, L., Shan, Z., Ren, H. (2016). Metagenomic analysis of bacterial community composition and antibiotic resistance genes in a wastewater treatment plant and its receiving surface water. Ecotoxicology and environmental safety, 132, 260-269.

Tomaszek, J. A., Czerwieniec, E. (2003). Dentrification and oxygen consumption in bottom sediments: factors influencing rates of the processes. Hydrobiologia, 504(1-3), 59-65.

Trottet, A., Leboulanger, C., Vidussi, F., Pete, R., Bouvy, M., Fouilland, E. (2016). Heterotrophic bacteria show weak competition for nitrogen in Mediterranean coastal waters (Thau Lagoon) in autumn. Microbial ecology, 71(2), 304-314.

Tundisi, J. G., Matsumura-Tundisi, T., Tundisi, J. E. M., Blanco, F. P., Abe, D. S., Campanelli, L. C., Galli, S., Silva, V. T., Lima, C. P. P. (2015). A bloom of cyanobacteria (Cylindrospermopsis raciborskii) in UHE Carlos Botelho (Lobo/Broa) reservoir: a consequence of global change?. Brazilian Journal of Biology, 75(2), 507.

Utermöhl, H. (1958). Zur vervollkommnung der quantitativen phytoplankton- methodik. Verhandlungen der Internationalen Vereinigung für Theoretische und Angewandte Limnologie, $9,1-38$.

Wang, L., Zhang, J., Li, H., Yang, H., Peng, C., Peng, Z., Lu, L. (2018). Shift in the microbial community composition of surface water and sediment along an urban river. Science of the Total Environment, 627, 600-612.

Wen, S., Wang, H., Wu, T., Yang, J., Jiang, X., Zhong, J. (2020). Vertical profiles of phosphorus fractions in the sediment in a chain of reservoirs in North China: Implications for pollution source, bioavailability, and eutrophication. Science of The Total Environment, 704, 135318.

Willis, A., Chuang, A. W., Burford, M. A. (2016). Nitrogen fixation by the diazotroph Cylindrospermopsis raciborskii (Cyanophyceae). Journal of phycology, 52(5), 854-862.

Yan, X., Jing-ming, L., Ai-hui, W., Sheng, Y. (2011). Study on Mechanism of Simultaneous Nitrification and Denitrification with Four Kinds of Fillers in Simulated Situ Bioremediation for Taihu Lake. Procedia Environmental Sciences, 10, 84-88.

Yang, Y., Gao, Y., Huang, X., Ni, P., Wu, Y., Deng, Y., Zhan, A. (2019). Adaptive shifts of bacterioplankton communities in response to nitrogen enrichment in a highly polluted river. Environmental pollution, 245, 290-299. 
Yu, C., Li, C., Wang, T., Zhang, M., Xu, J. (2018). Combined effects of experimental warming and eutrophication on phytoplankton dynamics and nitrogen uptake. Water, 10(8), 1057.

Yuan, X., Glibert, P. M., Xu, J., Liu, H., Chen, M., Liu, H., Liu, H., Yin, K., Harrison, P. J. (2012). Inorganic and organic nitrogen uptake by phytoplankton and bacteria in Hong Kong waters. Estuaries and Coasts, 35(1), 325-334.

Zhang, J., Kobert, K., Flouri, T., and Stamatakis, A. (2014). PEAR: a fast and accurate Illumina Paired-End reAd mergeR. Bioinformatics 30, 614-620.

Zhang, L., Zhao, T., Wang, Q., Li, L., Shen, T., Gao, G. (2019). Bacterial community composition in aquatic and sediment samples with spatiotemporal dynamics in large, shallow, eutrophic Lake Chaohu, China. Journal of Freshwater Ecology, 34(1), 575-589.

Zehr, J. P., Ward, B. B. (2002). Nitrogen cycling in the ocean: new perspectives on processes and paradigms. Appl. Environ. Microbiol., 68(3), 1015-1024.

Zehr, J. P., Kudela, R. M. (2011). Nitrogen cycle of the open ocean: from genes to ecosystems. Annual review of marine science, 3, 197-225.

Zumft, W. G. (1997). Cell biology and molecular basis of denitrification. Microbiol. Mol. Biol. Rev., 61(4), 533-616. 


\section{Supplementary material}

Table S2-1. N uptake rates (nmol L- $\left.{ }^{1} \mathrm{~h}^{-1}\right)$ by phytoplankton measured in Itupararanga and Lobo reservoirs. The percent contribution of each substrate to total nitrogen uptake is indicated in parentheses.

\begin{tabular}{|c|c|c|c|c|c|c|c|c|}
\hline \multicolumn{9}{|c|}{ Itupararanga reservoir } \\
\hline & \multicolumn{4}{|c|}{ River zone } & \multicolumn{4}{|c|}{ Dam zone } \\
\hline & May/2017 & Aug/2017 & Oct $/ 2017$ & Jan/2018 & May/2017 & Aug/2017 & Oct/2017 & Jan/2018 \\
\hline $\mathrm{NO}_{3}-$ uptake & $\begin{array}{c}19.0 \pm 0.37 \\
(59.9 \%)\end{array}$ & $\begin{array}{c}7.0 \pm 2.44 \\
(69.8 \%)\end{array}$ & $\begin{array}{c}515.9 \pm 24.6 \\
(90.7 \%)\end{array}$ & $\begin{array}{c}42.7 \pm 11.6 \\
(23.7 \%)\end{array}$ & $\begin{array}{l}7.9 \pm 0.5 \\
(25.4 \%)\end{array}$ & $\begin{array}{l}5.2 \pm 0.4 \\
(35.9 \%)\end{array}$ & $\begin{array}{c}26.2 \pm 3.8 \\
(17.1 \%)\end{array}$ & $\begin{array}{c}206.8 \pm 48.6 \\
(84.3 \%)\end{array}$ \\
\hline $\mathrm{NH}_{4}{ }^{+}$uptake & $\begin{array}{l}13.0 \pm 1.8 \\
(40.7 \%)\end{array}$ & $\begin{array}{l}3.0 \pm 0.4 \\
(30.2 \%)\end{array}$ & $\begin{array}{c}52.8 \pm 2.2 \\
(9.3 \%)\end{array}$ & $\begin{array}{c}137.3 \pm 25.2 \\
(76.3 \%)\end{array}$ & $\begin{array}{l}23.2 \pm 0.4 \\
(74.5 \%)\end{array}$ & $\begin{array}{l}9.2 \pm 0.1 \\
(64.1 \%)\end{array}$ & $\begin{array}{r}127.1 \pm 4 \\
(82.4 \%)\end{array}$ & $\begin{array}{c}38.3 \pm 1.0 \\
(15.6 \%)\end{array}$ \\
\hline \multicolumn{9}{|c|}{ Lobo reservoir } \\
\hline & \multicolumn{4}{|c|}{ River zone } & \multicolumn{4}{|c|}{ Dam zone } \\
\hline & May/2017 & Aug/2017 & Oct $/ 2017$ & Jan/2018 & May/2017 & Aug/2017 & Oct $/ 2017$ & Jan/2018 \\
\hline $\mathrm{NO}_{3}-$ uptake & $\begin{array}{l}22.0 \pm 0.5 \\
(60.4 \%)\end{array}$ & $\begin{array}{l}7.0 \pm 0.8 \\
(45.5 \%)\end{array}$ & $\begin{array}{l}8.4 \pm 0.6 \\
(21.7 \%)\end{array}$ & $\begin{array}{l}5.9 \pm 0.8 \\
(28.4 \%)\end{array}$ & $\begin{array}{l}53.7 \pm 3.0 \\
(71.0 \%)\end{array}$ & $\begin{array}{l}4.6 \pm 0.1 \\
(44.0 \%)\end{array}$ & $\begin{array}{l}9.8 \pm 1.2 \\
(15.6 \%)\end{array}$ & $\begin{array}{l}4.2 \pm 0.2 \\
(5.2 \%)\end{array}$ \\
\hline $\mathrm{NH}_{4}{ }^{+}$uptake & $\begin{array}{l}14.4 \pm 1.1 \\
(39.6 \%)\end{array}$ & $\begin{array}{l}8.4 \pm 0.4 \\
(54.5 \%)\end{array}$ & $\begin{array}{c}30.3 \pm 1.9 \\
78.3 \%\end{array}$ & $\begin{array}{l}14.8 \pm 1.9 \\
(71.6 \%)\end{array}$ & $\begin{array}{l}22.0 \pm 1.4 \\
(29.0 \%)\end{array}$ & $\begin{array}{l}5.9 \pm 0.2 \\
(56.0 \%)\end{array}$ & $\begin{array}{c}52.8 \pm 0.3 \\
(84.4 \%)\end{array}$ & $\begin{array}{r}76.2 \pm 0.2 \\
(94.8 \%)\end{array}$ \\
\hline
\end{tabular}

Table S2-2 Number of metagenomic reads and Domain contribution in Itupararanga and Lobo reservoirs.

\begin{tabular}{ccccccccc}
\hline & IRZM & IDZM & IRZJ & IDZJ & LRZM & LDZM & LRZJ & LDZJ \\
\hline Total n of reads & 29118909 & 35346111 & 30671137 & 28805611 & 24410056 & 23660107 & 32367644 & 24370723 \\
\hline $\begin{array}{c}\mathrm{N}^{\circ} \text { of reads post } \\
\text { quality control }\end{array}$ & 25003562 & 26579622 & 25181619 & 21407284 & 16768760 & 17832740 & 25860488 & 20190567 \\
$\begin{array}{c}\text { Reads average } \\
\text { length (bp) } \\
\text { Bacteria } \\
(\%)\end{array}$ & 108 & 108 & 107 & 109 & 108 & 107 & 107 & 107 \\
$\begin{array}{c}\text { Eukaryota } \\
(\%)\end{array}$ & 1.67 & 5.24 & 4.90 & 3.21 & 2.44 & 5.05 & 6.95 & 3.83 \\
$\begin{array}{c}\text { Archaea } \\
(\%)\end{array}$ & 0.17 & 0.07 & 0.13 & 0.08 & 0.12 & 0.07 & 0.12 & 0.13 \\
\hline $\begin{array}{c}\text { Viruses } \\
(\%)\end{array}$ & 0.05 & 0.05 & 0.14 & 0.15 & 0.33 & 0.16 & 2.31 & 1.60 \\
\hline
\end{tabular}

I: Itupararanga reservoir; RZ: River zone; DZ: Dam zone; L: Lobo reservoir 


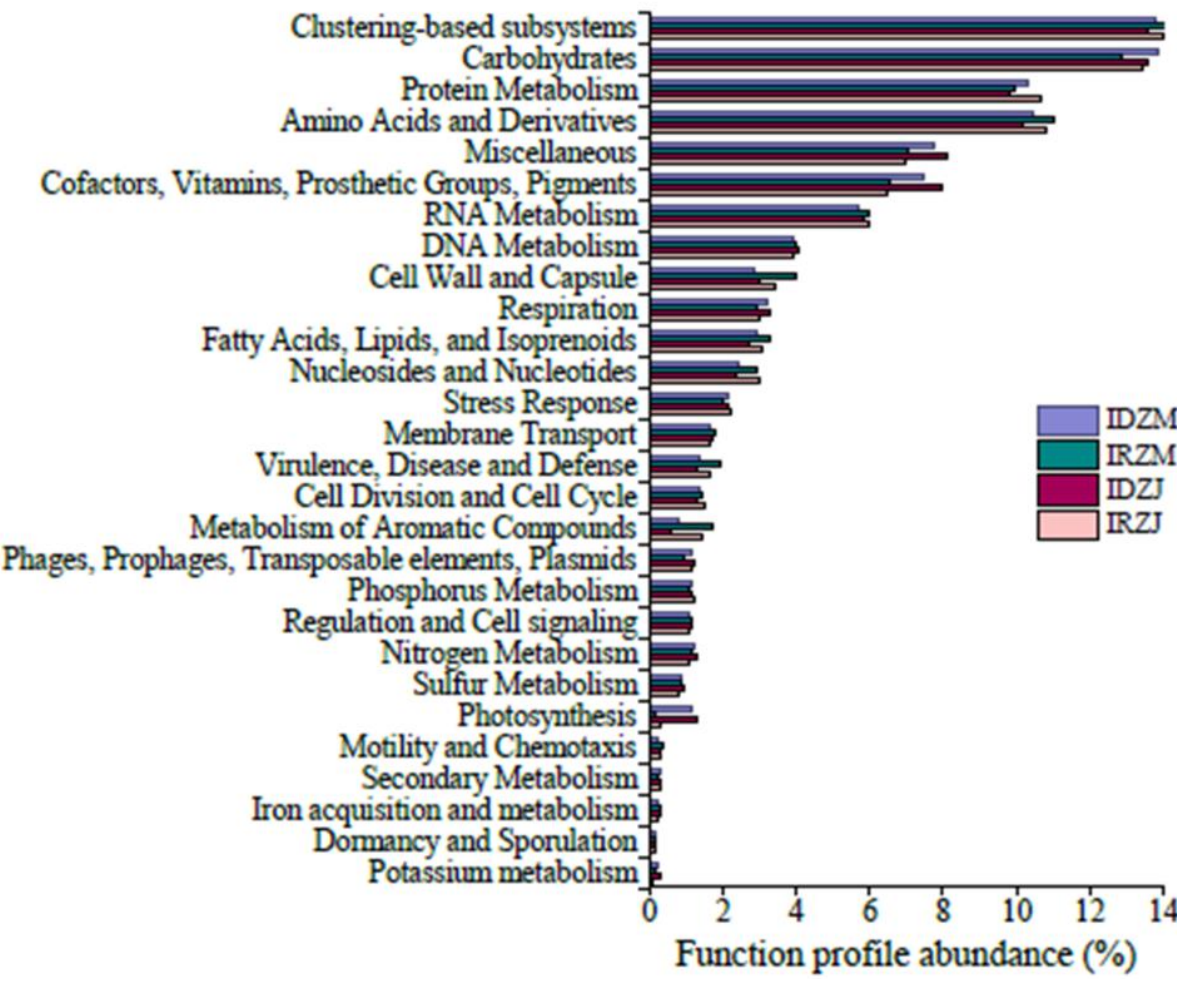

(A)

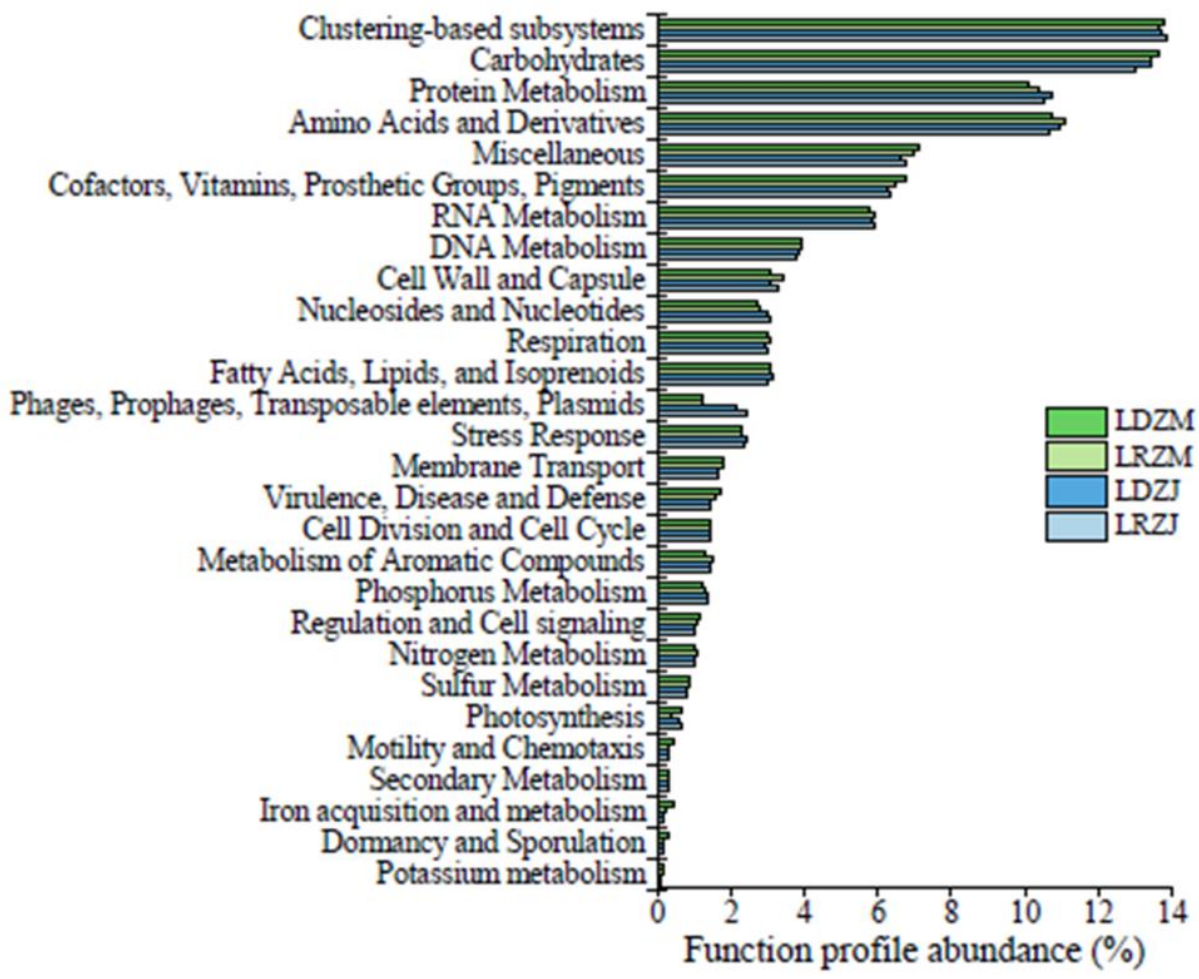

(B)

Figure S2-1. Functional profile at level 1 based on SEED subsystems of metagenomes obtained from river zone and dam zone in May/2017 and January/2018 in (A) Itupararanga reservoir and (B) Lobo reservoir. I: Itupararanga; RZ: River zone; DZ: Dam zone; L: Lobo. 
$95 \%$ confidence intervals

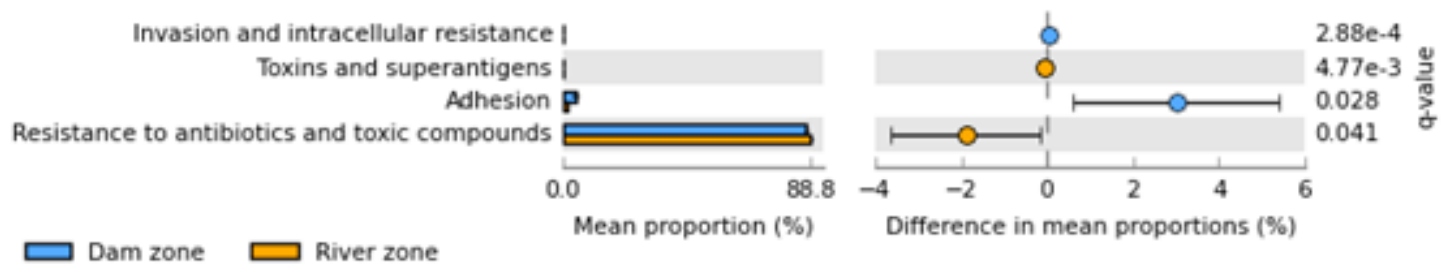

Figure S2-2. Significant differences in genes within "Virulence, Disease and Defense category" classified according SEED subsystems in metagenomes from Itupararanga reservoir 


\section{CONSIDERAÇÕES FINAIS}

Essa pesquisa contribuiu para ampliação dos conhecimentos sobre estrutura e composição das comunidades fitoplanctônicas e bacterianas de reservatórios subtropicais meso-eutróficos, Itupararanga e Lobo. Além disso, também foram analisados os papéis desses microrganismos em rotas metabólicas do ciclo do nitrogênio.

O primeiro capítulo trouxe uma análise exploratória sobre a estrutura da comunidade bacteriana e do fitoplâncton, inclusive do picofitoplâncton. Ao utilizar a citometria de fluxo, técnica de baixo custo e de rápido processamento de múltiplas amostras, foi possível estimar a biomassa das diferentes comunidades estudadas, além de analisar padrões temporais e espaciais da diversidade citométrica (cytometric fingerprinting). A diversidade citométrica permite detectar padrões em citogramas que podem refletir a diversidade da composição microbiana. Os resultados, neste presente estudo, mostraram que o fitoplâncton apresentou alta biomassa e correlação positiva com bactérias heterotróficas. Além disso, os padrões de diversidade citométrica indicaram que a composição bacteriana entre os reservatórios Lobo e Itupararanga é diferente, e que há significativa diferença entre amostras da cabeceira e barragem de Itupararanga. A biomassa de picocianobactérias foi composta principalmente de picocianobactérias ricas em ficocianinas, e esses microrganismos predominaram ou co-dominaram com picofitoplâncton eucarionte, indicando condições de mesotrofia nos ambientes. Por fim, os resultados obtidos mostraram que as variáveis ambientais transparência da água, $\mathrm{pH}$ e condutividade influenciaram significativamente as três comunidades avaliadas neste estudo, entretanto as concentrações de DOC e DIN foram significativas apenas para fitoplâncton e bactérias heterotróficas.

No segundo capítulo foi observado que a assimilação de nitrogênio está diretamente relacionada a maiores temperaturas, mas os resultados apresentados nesse presente estudo foram similares a estudos realizados em regiões temperadas. Através da análise metagenômica e dos experimentos de assimilação de nitrogênio, constatou-se que cianobactérias desempenham um papel chave na composição das comunidades microbianas e no metabolismo do nitrogênio em reservatórios. Devido alto potencial genético relacionado a fixação de nitrogênio e assimilação de nitrato em cianobactérias, sugere-se que esses microrganismos possuem flexibilidade de estratégias para capturar nitrogênio em ambientes com baixa disponibilidade de amônio, o que pode favorecer seu crescimento. Nos experimentos de assimilação de nitrogênio, cianobactérias foram 
positivamente correlacionadas com as taxas de assimilação de nitrato, corroborando com os resultados metagenômicos que mostraram alta abundância de genes relacionados ao transporte de nitrato, em amostras com alta abundância relativa de cianobactérias.

Apesar de bactérias heterotróficas terem apresentado alto potencial genético para assimilação de amônio, os experimentos com traçadores isotópicos mostraram que o fitoplâncton é o principal contribuinte para assimilação de nitrogênio inorgânico. Em contrapartida, diversas famílias de bactérias heterotróficas, como Burkholderiaceae e Comamonadaceae, foram relacionadas às rotas de desnitrificação, amonificação e inclusive fixação de nitrogênio, por isso esses microrganismos também desempenham papel fundamental no metabolismo do nitrogênio em ambientes aquáticos. Os resultados metagenômicos mostraram que explorar taxonomia e potencial funcional dos microrganismos pode ser uma interessante estratégia para avaliar possíveis indicadores de poluição.

Nessa pesquisa, a integração de diferentes ferramentas metodológicas utilizadas para o estudo do fitoplâncton e bacterioplâncton, permitiu uma melhor compreensão dos resultados obtidos, pois as análises realizadas se complementaram. Os resultados mostraram que as comunidades microbianas estão correlacionadas e que ambas desenvolvem papéis fundamentais no ciclo do nitrogênio em reservatórios subtropicais. Por isso, para compreender melhor os mecanismos de respostas dos microrganismos a perturbações no meio, recomenda-se integração de diferentes abordagens metodológicas e análise simultânea do bacterioplâncton e fitoplâncton.

Por fim, recomenda-se futuros trabalhos para investigar novas questões levantadas durante o desenvolvimento dessa pesquisa para (1) investigar se a formação de blooms de Ceratium furcoides é recorrente no reservatório Itupararanga e as causas desse processo, (2) investigar se correlação observada entre R. raciborskii e Mycobacteriaceae ocorre em uma escala temporal mais ampla em ambiente natural e analisar possíveis causas metabólicas por meio de experimentos em laboratórios, (3) explorar a diversidade microbiana e seu potencial funcional nos sedimentos dos reservatórios Lobo e Itupararanga, especialmente para investigar a presença de patógenos e de genes de resistência a antibióticos, (4) continuar explorando os metagenomas obtidos neste estudo para avaliar os papéis dos microrganismos em outras rotas metabólicas como do fósforo, enxofre e carbono. 
